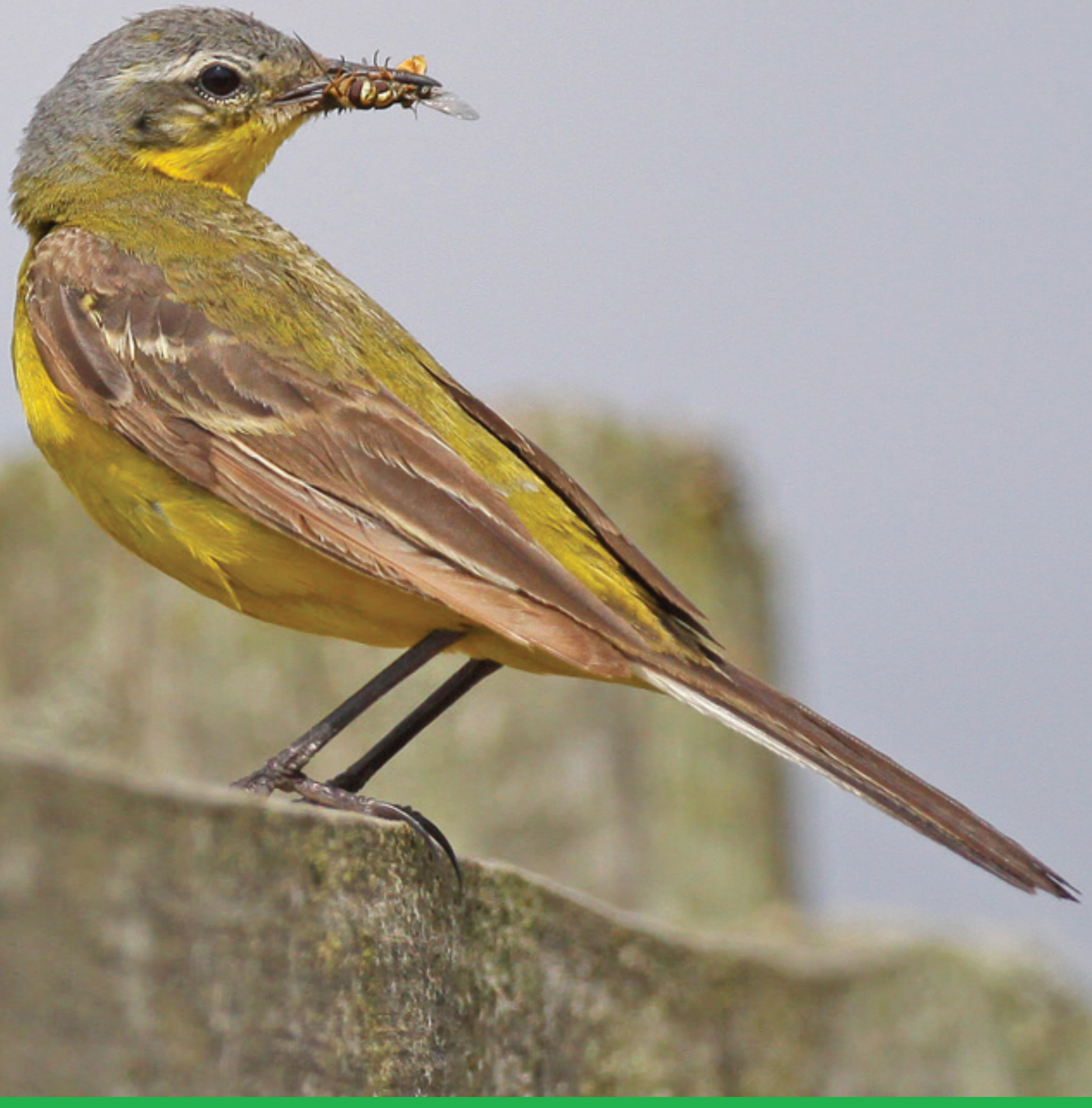

\title{
Akkervogelvriendelijk bouwplan met zomergraan en overwinterende stoppels
}

Eindrapportage 



\section{Akkervogelvriendelijk bouwplan met zomergraan en overwinterende stoppels}

Eindrapportage

R.H.E.M. Geerts ${ }^{1}$, H. Korevaar ${ }^{1}$, B. Koole ${ }^{2}$ en G.C.A. van Wijk ${ }^{3}$

1 Wageningen University \& Research

2 Bauke Koole Onderzoek Ecologie Educatie

3 ANV Wierde \& Dijk

Dit onderzoek is uitgevoerd door de Stichting Wageningen Research (WR), business unit Agrosysteemkunde, in opdracht van de ANV's Wierde \& Dijk en ANOG en met financiering van de provincie Groningen.

WR is een onderdeel van Wageningen University \& Research, samenwerkingsverband tussen Wageningen University en de Stichting Wageningen Research.

Wageningen, juni 2018

Rapport WPR-803 
Geerts R.H.E.M., Korevaar H., Koole, B., Wijk G.C.A van, 2018. Akkervogelvriendelijk bouwplan met zomergraan en overwinterende stoppels; Eindrapportage. Wageningen Research, Rapport WPR-803. 90 blz.; 30 fig.; 10 tab.; 24 ref.

Dit rapport is gratis te downloaden op https://doi.org/10.18174/453968

In de driejarige pilot Akkervogelvriendelijk bouwplan met zomergraan en overwinterende stoppels werd op negen akkerbouwbedrijven in Groningen een meerjarige teelt van zomergraan met overwinterende stoppels ontwikkeld en getoetst. Met een minimale inzet van chemie en grondbewerking is getracht een aantrekkelijk biotoop voor akkervogels te creëren dat tevens een gewas oplevert met een acceptabele opbrengst voor de deelnemende akkerbouwers en niet te veel problemen oproept met probleemonkruiden en op een effectieve wijze is in te passen in de bedrijfsvoering. De resultaten laten zien dat met name de overwinterende stoppels van grote waarde zijn voor akkervogels.

Trefwoorden: akkervogels, overwinterende stoppels, zomergraan, praktijkonderzoek

(C) 2018 Wageningen, Stichting Wageningen Research, Wageningen Plant Research, Business unit Agrosysteemkunde, Postbus 16, 6700 AA Wageningen; T 03174807 00; www.wur.nl/plant-research

KvK: 09098104 te Arnhem

VAT NL no. 8113.83.696.B07

Stichting Wageningen Research. Alle rechten voorbehouden. Niets uit deze uitgave mag worden verveelvoudigd, opgeslagen in een geautomatiseerd gegevensbestand, of openbaar gemaakt, in enige vorm of op enige wijze, hetzij elektronisch, mechanisch, door fotokopieën, opnamen of enige andere manier zonder voorafgaande schriftelijke toestemming van Stichting Wageningen Research.

Stichting Wageningen Research is niet aansprakelijk voor eventuele schadelijke gevolgen die kunnen ontstaan bij gebruik van gegevens uit deze uitgave.

Rapport WPR-803

Foto omslag: gele kwikstaart (Gerrit Kiekebos) 


\section{Inhoud}

Woord vooraf $\quad 5$

$\begin{array}{ll}\text { Samenvatting } & 7\end{array}$

$\begin{array}{ll}\text { Summary } & 9\end{array}$

1

$\begin{array}{ll}\text { Inleiding } & 11\end{array}$

1.1 Enkele achtergronden 11

1.2 Doelen 13

$\begin{array}{lll}1.3 & \text { Onderzoekvragen } & 13\end{array}$

1.4 Aanpak 13

1.5 Monitoring 14

1.5.1 Teelt van zomergraan en referentiegewassen 14

$\begin{array}{ll}1.5 .2 & \text { Ontwikkeling onkruiddruk }\end{array}$

1.5.3 Akkervogels in broedseizoen en winter $\quad 15$

1.5.4 Insecten op onderzoekspercelen en wintergraan 16

3.1 Teelt van zomergraan op de onderzoekspercelen $\quad 18$

3.1.1 Grondbewerking en inzaai onderzoekspercelen 19

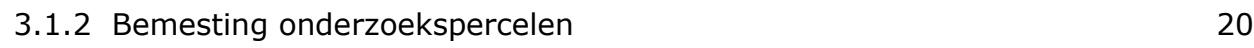

$\begin{array}{ll}3.1 .3 \text { Gewasbescherming onderzoekspercelen } & 21\end{array}$

3.1.4 Gewasopbrengst en kwaliteit graan onderzoekspercelen 23

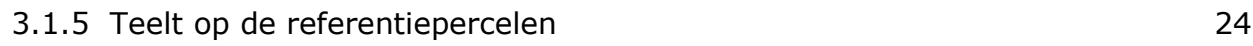

3.2 Ontwikkeling onkruiddruk 2015-2017 25

3.2.1 Percelen zonder gebruik van gewasbeschermingsmiddelen 28

3.2.2 Percelen met beperkte inzet van gewasbeschermingsmiddelen 30

3.2.3 Referentiepercelen wintertarwe, zomergranen, suikerbieten en
aardappelen

3.3 Akkervogels $\quad 35$

3.3.1 Waarnemingen in broedseizoen $\quad 35$

$\begin{array}{ll}\text { 3.3.2 Waarnemingen in winter } & 43\end{array}$

$\begin{array}{lll}3.4 & \text { Insecten } & 50\end{array}$

$4 \quad$ Praktijkervaringen met uitvoering van de pilot $\quad 53$

$5 \quad$ Discussie $\quad 54$

5.1 Beperkingen van deze proefopzet $\quad 54$

5.2 Betekenis van akker(on)kruiden voor zaadetende vogels $\quad 55$

5.3 Meerwaarde van driejarige teelt met zomergranen en overwinterende

5.4 De landbouwkundige waarde van een driejarige teelt met zomergranen en $\begin{array}{ll}\text { de inpasbaarheid in de bedrijfsvoering } & 57\end{array}$ 
Bijlage 1 Waargenomen akkeronkruiden op de onderzoekspercelen 2015-2017

Bijlage 2 Resultaten CLM milieumeetlat 2017 66

Bijlage 3 Zaaddichtheidsproef 2017 Ebelsheerd 68

Bijlage 4 Waargenomen soorten tijdens de broedvogeltellingen 2015-2017

Bijlage 5 Waargenomen vogelsoorten tijdens de wintertellingen 2015-2017

Bijlage 6 Akkerkruiden en hun betekenis voor zaadetende vogels 


\section{Woord vooraf}

"Geen geluid klinkt zo lenteachtig blij als het lied van de veldleeuwerik."

Dertig jaar geleden behoorde de veldleeuwerik tot de tien meest voorkomende broedvogels van Nederland. Door de intensiever wordende landbouw dreigt het jubelende en kenmerkende geluid van deze zangvogel nu langzaam te verstommen.

Maatregelen om de dalende stand te keren, mochten aanvankelijk niet baten. Zo leek er in 2010 een oplossing gevonden te zijn door de inzet van akkervogelpakketten. Deze pakketten hadden als doel veldleeuweriken en andere vogels in het akkerbouwgebied te behouden. Helaas bleken de akkerranden en winterveldjes in de dagelijkse bedrijfsvoering niet altijd inpasbaar.

Dit weerhield ons niet om door te gaan met zoeken naar een oplossing.

Als voorloper van de ontwikkeling naar Natuurinclusieve Landbouw bedachten de Groninger akkerbouwers zelf een manier waarop akkervogelbescherming beter ingepast kan worden in het bouwplan van akkerbouwbedrijven. Hun initiatief vormde in 2015 het startpunt van de driejarige pilot Akkervogelvriendelijk bouwplan met zomergraan en overwinterende stoppels.

Doel van deze pilot was het ontwikkelen van een beheerpakket dat voorziet in extensieve teelt van zomergraan waarvan de stoppels in de winter blijven staan. Door op deze manier te telen zijn er veel mogelijkheden voor akkerkruiden en insecten om in deze teelt mee te liften met als resultaat dat er voor akkervogels in dit gewas meer voedsel is.

Daarbij levert het de akkerbouwer ook nog een zekere oogst van het perceel op waardoor de beheervergoeding lager kan zijn. Met eenzelfde budget wordt hierdoor een groter oppervlakte aan beheerd gebied voor akkervogels gerealiseerd. Een win-win!

Ik hoop van harte dat de conclusies en resultaten in dit rapport bijdragen aan het bestendigen van toekomstige generaties van de veldleeuwerik zodat we het lied van deze bijzondere vogel nog lang mogen horen.

Henk Staghouwer

Gedeputeerde water natuur landbouw Groningen, 30 mei 2018 


\section{Samenvatting}

Uit eerder onderzoek is gebleken dat zomergranen in het bouwplan erg belangrijk zijn voor een voldoende aanbod van veilig en geschikt nesthabitat tijdens het broedseizoen en dat overwinterende, onkruidrijke graanstoppels zorgen voor een voedselrijk winterhabitat. Vanwege minder goede ervaringen met een te hoge onkruiddruk bij akkervogelbeheer op akkerranden en wintervoedselveldjes, namen in 2015 de agrarische natuurverenigingen ANOG en Wierde \& Dijk het initiatief voor een proef om een nieuw alternatief te ontwikkelen dat ruimte biedt aan akkervogels en beter in te passen is in het bouwplan in de verschillende regio's in Groningen (Hogeland, Oldambt en Veenkoloniën). In de driejarige proef Akkervogelvriendelijk bouwplan met zomergraan en overwinterende stoppels is op negen akkerbouwbedrijven in Groningen een meerjarige teelt van zomergraan met overwinterende stoppels ontwikkeld en getoetst op de praktische haalbaarheid in de bedrijfsvoering. In deze pilot is getracht om met een minimale inzet van chemie, minimale grondbewerking en geringere zaaizaadhoeveelheden bij inzaaien een aantrekkelijk biotoop voor akkervogels te creëren dat tevens een gewas oplevert met een acceptabele opbrengst voor de deelnemende akkerbouwers.

Dit onderzoek moet gezien worden als een praktijkproef waarbij al lerende een extensievere teelt van zomergranen werd ontwikkeld met als doel een beter biotoop voor akkervogels te bieden. De spreiding tussen de bedrijven in de wijze waarop de zomergranen werden geteeld was groot en geeft goed de variatie weer die in de praktijk verwacht kan worden in opbrengst, onkruidontwikkeling en vogelpopulatie op bouwland in Groningen.

In de proef werden op elk bedrijf teelt en opbrengst, ontwikkeling van onkruiddruk, akkervogels in broedseizoen en winter en eenmalig de aanwezige insectenpopulatie geïnventariseerd op proefpercelen met een aangepaste teelt van zomergraan en referentiepercelen met gangbaar geteelde wintertarwe (Hogeland en Oldambt) of zomertarwe/zomergerst (Veenkoloniën) en met aardappelen of suikerbieten. De deelnemers kregen gedurende de drie proefjaren de aangepaste teelt van zomergraan steeds beter in de vingers. Bemesting, grondbewerking en zaaidichtheid werden steeds meer geoptimaliseerd. Voor een aangepaste teelt van zomergraan op klei lijkt een opbrengst van 6 ton/ha reëel. Voor zand lijkt een opbrengst 5 ton per ha haalbaar.

Op de proefpercelen met zomergraan werd jaarlijks op drie momenten de onkruiddruk geïnventariseerd (in mei/juni, in juli vlak voor de oogst, in oktober op het stoppelveld). Daarbij is gekeken naar de ontwikkeling van de onkruidpopulatie op een perceelsgedeelte met een beperkte inzet van gewasbescherming en een deel van het perceel waar helemaal niet werd gespoten. Daarnaast werd op elk bedrijf vlak voor de oogst ook de onkruiddruk op de beide referentiepercelen geïnventariseerd. In het tweede jaar werd duidelijk dat helemaal niet spuiten geen praktische optie zou zijn en werd besloten deze variant niet voort te zetten in het derde jaar. De onkruiddruk op het onbespoten perceelsgedeelte was te hoog. Op de zomergraanpercelen met een beperkt gebruik van herbiciden blijkt dat de onkruiddruk op de drie bedrijven op zandgrond aanzienlijk hoger was dan op de klei. De onkruidbedekking op de 6 bedrijven op de klei op het Hogeland en Oldambt bleef onder de $10 \%$ bedekking, waarbij die op de bedrijven op zand in de Veenkoloniën tussen de 20 en $50 \%$ lag.

Tijdens het broedseizoen zijn tussen half april en half juli vijf (2015) of zes (2016 en 2017) telrondes gehouden om broedvogels te inventariseren. In totaal zijn op de onderzoeks- en referentiepercelen 100 verschillende vogelsoorten waargenomen. Voor 9 typische akkervogels zijn de waarnemingen in detail uitgewerkt. Sterk van invloed op de aanwezigheid van soorten is het habitat. Komen er slootkanten, ruige grasranden, rietkragen of ingezaaide faunaranden in de directe nabijheid van de percelen voor, dan is dit terug te zien in hogere aantallen vogels. Het totaal beeld van de 9 akkervogelsoorten over de hele onderzoeksperiode laat zien dat de hakvruchten op de klei (Hogeland en Oldambt) het slechts scoren. Tussen de zomergranen en gangbaar geteelde wintertarwe op klei (Hogeland en Oldambt) zijn de verschillen gering maar lijkt wintergraan wat beter te scoren t.o.v. 
zomergraan. Op zand in de Veenkoloniën scoren de proefpercelen met zomergraan beter dan gangbaar geteeld zomergraan en hakvruchten. Het verschil met de regio's op klei wordt vooral veroorzaakt door soorten als ringmus, geelgors en kneu die vaker op de bedrijven in de Veenkoloniën werden aangetroffen, soorten van een wat meer kleinschaliger, half open landschap.

In de winter zijn tussen half oktober en half maart acht telrondes gehouden om zicht te krijgen op de soorten en aantallen die in herfst en winter op de percelen foerageren. In totaal zijn tijdens de wintertellingen 64 vogelsoorten waargenomen, daarvan zijn 25 soorten die als zaadeters een voorkeur hebben voor de zomergraanstoppels, echter hakvruchten scoren op sommige momenten, vanwege de nog aanwezige gewasresten, ook goed. Naast zaden eten veel vogels ook groene plantendelen. Door de begroeiing met (bloeiende) grassen en onkruiden, achtergebleven graankorrels, gewasopslag en stoppels hebben de zomergraanstoppels een grote aantrekkingskracht op akkervogels. De aantallen en soorten die zijn aangetroffen variëren sterk gedurende het winterseizoen, afhankelijk van o.a. de vogeltrek en weersituatie. Naast foerageren worden de percelen ook gebruikt voor dekking en rusten. Als we naar een aantal specifieke akkervogelsoorten kijken, dan valt op dat een soort als de veldleeuwerik vooral aangetroffen werd op de klei in Hogeland en Oldambt op zomergraanstoppels en in geringere mate op zomergraanstoppels op het zand in de Veenkoloniën. Een soort als de geelgors heeft duidelijk een voorkeur voor graanstoppels op zandgrond in de Veenkoloniën. Naast de zaadeters werden tijdens de winterwaarnemingen ook 7 soorten roofvogels en reigers geteld die als muizenspecialisten geen echte voorkeur voor de zomergraanstoppels bleken te hebben. Zowel de percelen waar hakvruchten of wintergranen hebben gestaan als de zomergraanstoppels worden gedurende de hele winter regelmatig door roofvogels en reigers bezocht.

Omdat er slechts eenmalig, in juni 2017, een inventarisatie van insecten kon worden uitgevoerd, moeten deze uitkomsten met de nodige voorzichtigheid worden geïnterpreteerd. De insecten op de proefpercelen met zomergraan zijn vergeleken met die op het referentieperceel met gangbaar geteelde wintergraan (en op de drie bedrijven in de Veenkoloniën met gangbaar geteeld zomergraan). Uit de resultaten kan (voorzichtig) de conclusie worden getrokken dat een verminderde inzet van herbiciden en insecticiden in de proefpercelen met zomergraan een positief effect lijkt te hebben op het insectenleven. Er werden vaker exemplaren gevangen van insectengroepen die belangrijk zijn als vogelvoer en als natuurlijke vijanden van plagen.

Samenvattend kan geconcludeerd worden dat een aangepaste teelt van zomergraan vooral positief uitpakt voor overwinterende akkervogels en neutraal is voor broedende akkervogels in vergelijking met referentiegewassen gangbaar geteelde wintertarwe of zomergraan en aardappelen/suikerbieten. Positief voor de akkervogels is dat er meer insecten en onkruidzaden beschikbaar zijn bij de aangepaste teelt van zomergraan. Uit de reacties van de deelnemende akkerbouwers kan geconstateerd worden dat de meeste ondernemers zomergraanteelt met een beperkt herbicidegebruik inpasbaar achten in de bedrijfsvoering. De aangepaste teelt van zomergraan met beperkte grondbewerking, lagere zaaidichtheid en beperkt gebruik van gewasbescherming resulteert echter in een lagere graanopbrengst in vergelijking met de gangbare teelt van winter- en zomergraan.

De resultaten van dit onderzoek bieden een goed houvast voor een nieuw akkervogelpakket voor Agrarisch natuur- en landschapsbeheer. Uit de pilot bleek duidelijk dat de duur van drie jaar een goede keuze was. Dat wil niet zeggen dat een toekomstig zomergraanpakket altijd drie jaar achtereen op hetzelfde perceel moet liggen. Op zware klei zou je kunnen starten met de stoppel van de voorgaande wintertarwe. Op bedrijven met een bouwplan met zetmeelaardappelen past vanwege de rotatie drie jaar achtereen zomergraan op hetzelfde perceel ook niet. Niet het aantal jaren, maar de aanwezigheid van voldoende areaal graanstoppelvelden in de winter is de belangrijkste factor om een goed habitat voor akkervogels te bieden. 


\section{Summary}

Previous studies highlighted the importance of summer wheat in crop rotations for farmland bird conservation. The crop provides nesting and shelter when birds breed in summer. During winter stubbles and weeds play an important role in feed provision and habitat.

Projects addressing farmland bird protection on field margins and special winter feeding plots often resulted in persistent weed establishment, which resulted in objections against those management options. In 2015 the agrarian conservation trusts ANOG and Wierde \& Dijk started a new initiative in three regions of the province in Groningen (Hogeland, Oldambt and Veenkoloniën). The initiators had the intention to address farmland birds habitats requirements within crop rotation in existing farming systems. On nine arable farms in Groningen a three years experiment on bird friendly crop rotation with summer wheat followed by winter stubbles was established. The experimental setting and management were carried out by farmers themselves. Measurements included quantitative and qualitative yield assessment and linking that to improved conditions for biodiversity by management adaptations. Management strategies were minimization of chemical inputs, reduced soil tillage and reduced seed quantities when sowing to create a more attractive habitat for farmland bird. Since the crop of the field experiments were influenced by the farmers individual management, the results were highly variable. However they are considered to be representative for arable farming systems in Groningen.

Data collection on the experimental plots included crop management, yield, weed establishment and numbers of bird populations during the breeding season as well as during the winter. Finally an assessment of insect populations was carried out at the end of the project. The treatments allowed comparison of bird friendly summer wheat with two references: a conventional produced winter wheat (Hogeland en Oldambt) of summer wheat/barley crop (Veenkoloniën) and potatoes or sugar beets. Since the selected farmers were highly interested in this system, fine-tuning of bird friendly summer wheat production was observed for the duration of the project. Optimization meant adapted fertilization, tillage and seeding density and results into an average yield of 6 ton/ha on clay soil and 5 ton/ha on sandy soil.

Measurements of weed establishment were taken three times a year during May/June, before harvest in July and in the remaining stubbles in October. The project aimed to compare treatments with reduced herbicide application and treatments without herbicide application. Next to this the conventional managed plots were monitored for weed establishment before harvest. Due to massive weed problems, treatments with zero herbicide application were terminated already in the second year. Reduced herbicide application resulted in lower weed abundance on clay soil as compared to sandy soil. The weed cover on 6 farms at Hogeland en Oldambt were less than $10 \%$, whereas weed cover on farms on sandy soils in the Veenkoloniën ranged between $20 \%$ to $50 \%$.

During the bird breeding season transect counting of birds from Mid April till Mid July (5 times in 2015) and ( 6 times in 2016 and 2017) were carried out. In total 100 bird species had been observed on the ploots. For 9 representative arable bird species, the counts are presented in detail. Presence of birds is highly dependent on the habitat in a landscape. This means higher numbers of birds were present in fields close to ditches and/or highly diverse grasslands margins, reed and bufferstrips containing plants attractive for fauna conservation. Least numbers of birds were found in the plots with sugar beet and potatoes on clay soil (Hogeland en Oldambt). There was a trend of higher bird numbers on winter wheat as compared to the bird friendly cultivated summer wheat. On sandy soil bird numbers were higher on bird friendly summer wheat as compared to the conventional produced winter wheat, or potatoes and sugar beet. Farms on clay and sandy soils differed in their characteristic bird species populations. Higher numbers of tree sparrows, yellowhammer and linnet were found in the half open landscape of the sandy Veenkoloniën. 
To include the benefits of stubbles to the birds for foraging during the winter season, eight transect countings) were carried out between Mid October and Mid March. During this period 64 bird species were observed, of which 25 species are seedeaters with preference of foraging in the stubbles of the summer wheat.

On these stubble fields food was provided during winter by remaining flowering plants and weeds, residual grains and crop residues and stubbles and offered a preferred habitat by birds. Next to foraging, the stubble fields are of importance for shelter and resting. But also arable fields used for potatoes and beet production during summer, are preferred by birds in the winter when crop residues are on the field serving as winter feed. Transect counts however showed that bird species presence were highly variable during the winter season, due to the birds dependency on migration and weather.

Larger numbers of the skylark were found in Hogeland and Oldambt on summer wheat stubbles on clay soil and less on summer wheat stubbles on sandy soil. The yellow hammer however prefers stubbles on sandy soil. Also 7 species of birds of prey and herons visited the fields during the winter, however no preferences for stubbles or crop residues were found for these mainly mouse eating birds.

Insect population measurements were carried out at the end of the project in June 2017. Insect diversity and numbers in bird friendly grown summer wheat were compared to numbers in winter wheat on 6 farms on clay and 3 farms on sandy soil with conventional produced summer wheat. The results gave an indication that reduced herbicide and insecticides application had an beneficial effect on insect populations. In the plots with reduced herbicide and pesticide control higher numbers and diversity of insect species were observed functioning as bird feed and biological control.

Summarizing this research, it can be concluded that an adapted cultivation of summer wheat has positively affects overwintering birds. No added effect was found for breeding farmland birds in the summer when comparing bird friendly summer wheat with conventional produced winter wheat/ summer wheat and/or potatoes/beet. The presence of weed seeds and insects remains highly important for birds. Farmers are generally willing to implement summer wheat with reduced herbicide application in their crop rotation. Even though bird friendly summer wheat production with reduced tillage, reduced seed density and reduced herbicide application results in lower yields as compared to conventional produced summer/winter wheat.

The findings of this research support the implementation of a new farmland bird friendly cropping scheme benefitting nature and landscape conservation. Three years of measurements allow to draw robust conclusions. Above all it needs remarking that summer wheat in crop rotation does not necessarily be carried out from year to year on the same field. On heavy clay soil the stubbles of the previous winter wheat are a perfect starting point. On farms with starch potatoes the frequency of summer wheat will be reduced due to fact that farmers want to grow potatoes in a higher frequent. Not the duration, but the presence of a sufficient area of stubbles during the winter is most important factor to provide suitable habitat for farmland birds. 


\section{$1 \quad$ Inleiding}

In 2015 is een driejarige pilot op negen Groningse praktijkbedrijven gestart waarin een meerjarige teelt van zomergraan met overwinterende stoppels werd ontwikkeld en getoetst op de praktische haalbaarheid in de bedrijfsvoering. In deze pilot is getracht om met een minimale inzet van chemie en minimale grondbewerking een aantrekkelijk biotoop voor akkervogels te creëren dat tevens een aantrekkelijk gewas oplevert voor de deelnemende akkerbouwers, niet te veel problemen oproept met probleemonkruiden en waarvoor het benodigde vergoedingsbedrag lager kan liggen dan voor de huidige SNL-pakketten.

In de eerste tussenrapportage (Geerts \& Korevaar, 2016) zijn de achtergronden en opzet van het onderzoek uitgelegd en zijn de resultaten van het eerste teeltseizoen uitgebreid weergegeven. Voor het tweede teeltjaar is een beknopte interne rapportage gemaakt. Nu, na afloop van het derde teeltjaar geven we in dit eindrapport een volledig overzicht van de resultaten en gaan we in op de vraag of deze teelt een alternatief of aanvulling op de huidige agrarisch natuurbeheerpakketten kan vormen.

\subsection{Enkele achtergronden}

In 1989 startte het Akkervogelmeetnet van de provincie Groningen waarin de aandacht gevestigd werd op vogelsoorten die tot dan toe onderbelicht bleven in het natuurbeleid. Akkervogels staan onder grote druk door het veranderde landschap en de intensivering van de landbouw. Door het 'Groninger model' wist de provincie Groningen als eerste in Nederland akkervogelkerngebieden te realiseren: kansrijke gebieden waarin natuurmaatregelen geconcentreerd zouden worden. Om het beleid te toetsen werden als doelsoorten de veldleeuwerik en de grauwe kiekendief gekozen (Wiersma et al., 2014). De Stichting Werkgroep Grauwe Kiekendief heeft in afgelopen jaren baanbrekend onderzoek gedaan in Nederland aan akkervogels, zowel naar populatieontwikkeling, verspreiding, gedrag, habitat keuze als ook naar de reacties van verschillende (akker)vogelsoorten op beheersmaatregelen in het agrarisch gebied. Recent heeft de werkgroep een uitgebreide evaluatie van de effectiviteit van het akkervogelbeheer in de provincie Groningen gepubliceerd (Wiersma et al., 2014).

Bos et al. (2010) hebben onderzoek gedaan naar de effectiviteit van soortgerichte maatregelen voor patrijs, veldleeuwerik en geelgors om te voorzien in de 'grote drie behoeften' voor akkervogels, namelijk: broedgelegenheid en dekking, voldoende aanbod van toegankelijk zomervoedsel (d.w.z. insectenrijke habitats in nabijheid van het nest) en voldoende aanbod van wintervoedsel (graankorrels, onkruidzaden). Voor bijna alle maatregelen die gericht zijn op één soort geldt dat de andere soorten in principe kunnen meeliften. Ook uit buitenlandse literatuur, o.a. Engeland, is bruikbare kennis voor het beheer van akkervogels te ontlenen.

Wiersma et al. (2014) concludeerden dat de aantallen vogels aangetroffen in wintervoedselveldjes de aantallen in controlevelden ruimschoots overtroffen. Op de getelde percelen werd de aanwezigheid van 47 vogelsoorten vastgesteld. Gemiddeld werden per telling 0.7 soorten vastgesteld in controlegebieden, tegen 2.2 op stoppelvelden en 3.4 soorten in Vogelakkers. In aantallen en in soortenrijkdom overstijgen de wintervoedselveldjes, Vogelakkers en graanstoppels vele malen de dichtheden in het gangbaar beheerde boerenland. Dit is vooral het gevolg van de grondbewerkingen die in de gangbare agrarische bedrijfsvoering direct na de oogst plaatsvinden. In de Veenkoloniën en in het Oldambt wordt respectievelijk $72 \%$ en $82 \%$ van de akkers in de herfst omgeploegd of ondergaat anderszins een ingrijpende grondbewerking. Hiermee gaat veel voedsel voor overwinterende vogels verloren. Verhoging van beschikbaarheid van wintervoedsel kan een positieve uitwerking hebben op lokale broedpopulaties.

Graanstoppels bieden voedsel door achtergebleven graankorrels, opslag van gekiemd graan en akkeronkruiden die na de oogst ruimte krijgen en uitgroeien. In Bijlage 6 staat een lijst van 
akkeronkruiden en hun betekenis als voedselbron voor zaadetende vogels op basis van Engels onderzoek.

Bos et al. (2010) bevelen aan om te zorgen voor overwinterende, onkruidrijke graanstoppels en wintervoedselgewassen om de winteroverleving te vergroten. Een soort als de geelgors zal hiervan kunnen profiteren. Overwinterende graanstoppels vormen niet per definitie een voedselrijk winterhabitat. Voor voedselrijke graanstoppels moet een specifiek beheer worden gevoerd waarin de ontwikkeling van onkruiden wordt getolereerd. Bos et al. (2010) geven ook aan dat niet goed bekend is hoe de voor vogels waardevolle stoppels het beste beheerd kunnen worden en wat de eventuele gevolgen zijn van onkruidrijke graanstoppels voor de volggewassen.

Voor een voldoende aanbod van veilig en geschikt nesthabitat tijdens het broedseizoen hebben veldleeuweriken volveldse maatregelen nodig, waarvan de vergroting van het aandeel zomergranen in het bouwplan één van de belangrijkste is (Bos et al., 2010). Daar staat tegenover dat een voldoende areaal zomergranen op zich geen garantie vormt voor een voldoende aanbod van insectenrijk foerageerhabitat voor oudervogels. Een gebied met een voldoende aanbod van voor broedende vogels geschikte gewassen maar zonder randen, brengt een risico met zich mee dat oudervogels weliswaar voldoende broedpogingen kunnen ondernemen, maar dat het broedsucces toch te laag blijft door gebrek aan foerageermogelijkheden. Verder is het waarschijnlijk dat semi-natuurlijke habitats zoals akkerranden een belangrijke rol spelen bij de conditieopbouw van broedende vogels; een basisvereiste voor het kunnen produceren en grootbrengen van meerdere legsels. Bos et al. (2010) verwachten daarom veel van de combinatie van zomergranen en akkerranden. Door het achterwege laten van herbicidetoepassing in gewas en op de stoppels wordt de ontwikkeling van een onkruidvegetatie getolereerd, die in de winter, maar ook tijdens het broedseizoen zorgt voor een groter voedselaanbod. Voorlopige ervaringen van onderzoek van Bos (2013) duiden er op dat het tolereren van onkruiden in overwinterende stoppels niet hoeft te leiden tot een drastische toename van onkruiden in de volggewassen.

Ervaringen van afgelopen jaren met SNL-akkerbouwpakketten laten zien dat de onkruiddruk van akkerdistels en melkdistels (Hogeland) (Figuur 1), akkerdistels en duist (Oldambt) en bijvoet (Veenkoloniën) bij de meerjarige akkerbouwpakketten in toenemende mate voor problemen zorgt, waardoor akkerbouwers minder gemotiveerd raken om deze pakketten in hun bedrijfsvoering op te nemen.

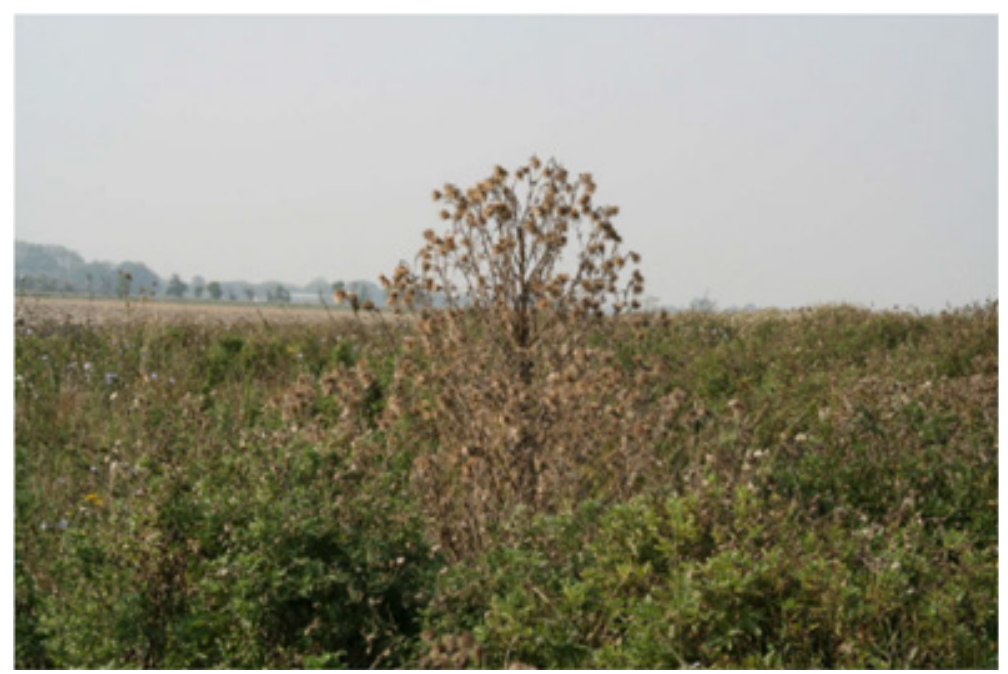

Figuur $1 \quad$ Sterke veronkruiding met distels.

In deze pilot hebben we voortgebouwd op bovenstaande bevindingen en hebben we op praktijkbedrijven de meerjarige teelt van zomergraan met overwinterende stoppels verder ontwikkeld en getoetst op de praktische haalbaarheid in de bedrijfsvoering. 


\subsection{Doelen}

Het doel van de pilot Akkervogelvriendelijk bouwplan met zomergraan en stoppels was het ontwikkelen van een driejarige teelt van zomergraan met overwinterende stoppelvelden die aantrekkelijk is voor akkervogels, geen grote onkruidproblemen veroorzaakt en op een effectieve en relatief goedkope wijze is in te passen in de bedrijfsvoering van de verschillende Groningse regio's.

\subsection{Onderzoekvragen}

De onderzoeksvragen waarop deze pilot zich richtte, waren:

- Wat is de waarde van een minder intensieve zomergraanteelt (incl. bijbehorende stoppel) voor:

- biodiversiteit (onkruidontwikkeling, akkervogels en insecten);

- bedrijfsvoering (graanopbrengsten en inpasbaarheid van zomergraanteelt met overwinterende stoppels in het bouwplan);

- acceptie van de teeltwijze door akkerbouwers.

Daarbij werd speciaal aandacht besteed aan de wijze waarop meerjarige zomergraanpercelen het beste beheerd kunnen worden om de biodiversiteit te vergroten in combinatie met onkruidbeheersing en rentabiliteit op het bedrijf

\subsection{Aanpak}

De aanpak omvatte drie hoofdcomponenten:

- een meerjarige teelt van zomergraan versus een gangbaar bouwplan, regio-specifiek rekening houdend met bouwplanverschillen in verschillende Groningse regio's;

- een minder intensieve teelt van zomergraan met

- een minimale inzet van chemie in deze teelt

- een minimale grondbewerking

- een lagere zaaidichtheid;

- overblijvende stoppels in herfst/winter.

Vertrekpunt vormde de afspraak om op 9 praktijkbedrijven: 3 op het Hogeland (lichte kleigrond), 3 in het Oldambt (zware kleigrond) en 3 in de Veenkoloniën (dalgrond) op een perceel zomergraan te telen:

$>$ Een perceel van ca. 2 ha waarop drie jaar achtereen zomergraan wordt geteeld en waarbij de stoppel de hele winter tot begin maart blijft staan. De percelen zomergraan worden meerdere jaren achtereen gevolgd om de opbouw van de onkruiddruk te kunnen meten. Het moeten bij de start van het project homogene percelen zijn en ze moeten als uitgangsituatie een 'normale' onkruiddruk hebben. De percelen worden vervolgens in twee gedeelten verdeeld. Op het ene gedeelte worden geen herbiciden en insecticiden toegediend. Dit gedeelte is minimaal 0,2 ha groot. Op het andere deel zullen herbiciden alleen en in minimale dosering ingezet worden als dit strikt noodzakelijk is om probleemonkruiden het hoofd te bieden. Ook op dit deel worden geen insecticiden gebruikt.

Daarnaast werden op elk bedrijf voor vergelijking twee controlepercelen meegenomen:

$>$ Controle 1. perceel wintertarwe op de klei of een gangbaar geteeld zomergraan op zandgrond in de Veenkoloniën

$>$ Controle 2. perceel aardappelen of suikerbieten (op lichtere gronden) of suikerbieten (op zwaardere gronden) dat in herfst geploegd wordt en in de winter kaal ligt.

Afhankelijk van de vruchtwisseling in het bouwplan zijn jaarlijks andere percelen als controlepercelen geselecteerd. 
Op elk bedrijf lagen de drie percelen op een vergelijkbare grondsoort en er werd zoveel mogelijk wordt naar gestreefd dat de externe factoren die van invloed op vogels kunnen zijn, zoals de nabijheid van wegen, erven en hoge beplanting, voor de drie percelen van een bedrijf vergelijkbaar waren. Het beheer van de beide controlepercelen werd aan de boer overgelaten. De proefpercelen met zomergraan kregen een minimale grondbewerking en een lagere zaaidichtheid. De minimale grondbewerking en zaaidichtheid werden in overleg met de begeleidingsgroep en - mede gebaseerd op de ervaringen in voorgaande jaren en regionale verschillen - jaarlijks besproken en nader gedefinieerd. Het bedrijf mocht kiezen tussen zomertarwe (had onze voorkeur) en zomergerst of haver (bijv. als dat beter in bedrijfsvoering was in te passen (Veenkoloniën)). Per bedrijf werden over gewaskeuze, grondbewerking en zaaidichtheid vooraf afspraken gemaakt.

\subsection{Monitoring}

\subsubsection{Teelt van zomergraan en referentiegewassen}

Op de praktijkbedrijven werden de gewassen geteeld volgens de op het bedrijf gebruikelijke wijze, met uitzondering dat er op het perceel zomergraan geen of in beperkte mate herbiciden werden ingezet, de zaaidichtheid lager was, dat er na de oogst een minimale grondbewerking plaatsvond en de stoppel de winter over bleef liggen tot minimaal 1 maart. Van het perceel zomergraan en de controlepercelen werden teeltgegevens zoals grondbewerkingen, zaaizaadhoeveelheid, bemesting, gewasbescherming, gewasopbrengsten en gewaskwaliteit vastgelegd in een teeltregistratiesysteem.

\subsubsection{Ontwikkeling onkruiddruk}

De monitoring van de onkruidontwikkeling vond plaats vanwege de biodiversiteit (de kruiden bieden in de winter via zaden en de groene delen voedsel aan akkervogels en zoogdieren, en in de zomer trekken ze insecten aan die op hun beurt weer als voedsel voor (jonge) akkervogels dienen) en het risico op veronkruiding van de gewassen (met evt. negatieve gevolgen voor gewasopbrengst en/of gewaskwaliteit). De monitoring van akkerkruiden werd uitgevoerd door de bedekking van de bodem met onkruiden te meten op drie momenten: eind mei/begin juni, vlak voor de oogst en in de stoppel voor de vorst.

\section{Monitoringsmethode}

- Op beide perceelsgedeelten zomergraan en beide controlepercelen werden 12 plotjes van 0,7 $\mathrm{m}^{2}$ geteld.

- De 12 plotjes werden volgens een aantal diagonale lijnen gelijk over het perceel verdeeld. Rijsporen werden gemeden.

- Binnen die 0,7 $\mathrm{m}^{2}$ werd de bedekking van de onkruiden geschat door te werken met een raster van 100 vakjes van elk $70 \mathrm{~cm}^{2}$ (elk vakje komt overeen met $1 \%$ bedekking).

- Van elke soort werd de naam genoteerd en het bedekkingspercentage geschat. Ook werd genoteerd welke soorten in bloei stonden en/of zaad hadden gevormd.

- Het raster werd in granen net boven het gewas geplaatst. In de gewassen als aardappelen en suikerbieten werkte dit niet, dit zijn te zware en dichte gewassen. Hier werd tussen de rijen gemeten met meterpiketten en de bedekking geschat

- Op elk perceels(gedeelte) werden tijdens de waarnemingsrondes foto's gemaakt om achteraf een beeld te hebben van de onkruiddruk en het gewasstadium. 

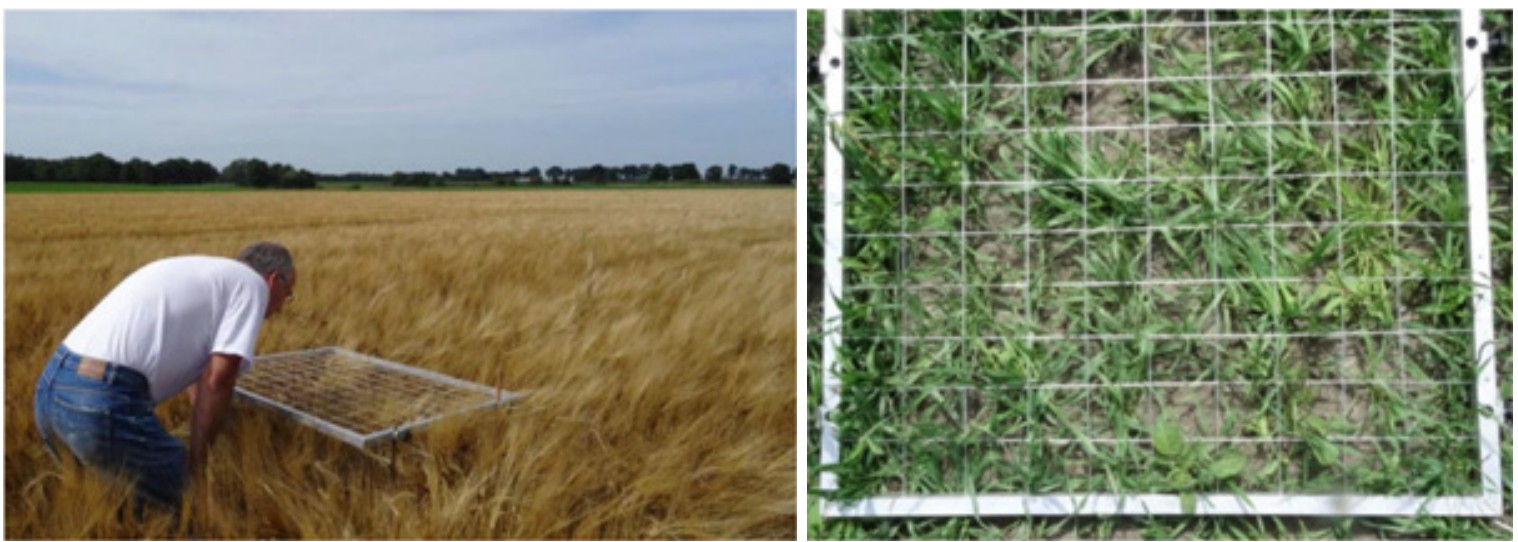

Figuur $2 \quad$ Werken met warnemingsraster.

\subsubsection{Akkervogels in broedseizoen en winter}

\section{Broedvogeltellingen}

Het doel van de broedvogelmonitoring is dat we wilden weten of de extensieve zomergraanteelt door broedvogels geprefereerd wordt boven gangbare geteelde zomer- en wintergranen en andere op de bedrijven aanwezige gewassen. De monitoring van broedvogelterritoria werd op vijf (2015) of zes (2016 en 2017) momenten tussen half april en half juli uitgevoerd op zowel op de zomergraanpercelen als de controlepercelen.

\section{Monitoringsmethode}

- De extra telrondes in 2016 en 2017 zijn gedaan omdat door sterk wisselende weersomstandigheden gewassen pas laat op gang kwamen en de indruk bestond dat zomersoorten (zoals kwartel en kwartelkoning) zich hierdoor pas laat zouden vestigen. In 2016 bleek dit te kloppen waardoor in 2017 opnieuw een zesde telling heeft plaatsgevonden.

- De tellingen hebben plaatsgevonden conform de methodiek van Bibby (Bibby et al., 2000).

- De percelen waarop de tellingen hebben plaatsgevonden waren in de meeste gevallen langwerpig en gemiddelde genomen vrij klein, zo rond de twee hectare. Hierdoor was het niet mogelijk om een volledig BMP-onderzoek uit te voeren conform de eisen van SOVON (Van Dijk \& Boele, 2011). SOVON stelt als eis dat een BMP-onderzoek op een eenheid van minimaal tien hectare moet plaatsvinden.

- Als telmethode is gekozen voor een onbegrensde transecttelling door de percelen. Alle vogels en zoogdieren die zich op of in de directe nabijheid van de percelen bevonden, zijn exact ingetekend op een digitale kaart. De waarnemingen zijn voorzien van de broedcodes van SOVON. Er is geteld vanaf zonsopkomst tot soms laat in de ochtend, afhankelijk van weersomstandigheden en tijd van jaar. Er is bij voorkeur geteld onder gunstige weersomstandigheden met zonnig en windstil weer.

- Door de geringe grootte van de onderzoekspercelen zijn de waarnemingen niet herleid tot territoria.

- Alle waarnemingen zijn geïmporteerd in een geografisch informatiesystem (GIS) en vervolgens ruimtelijk geanalyseerd door de broedvogeldata te combineren met de landschapskenmerken grondsoort, regio en gewas en met de beheerfuncties onderzoeksperceel, hakvrucht en granen.

- Om de percelen ecologische te borgen in het landschap is gebruik gemaakt van een buffer van 50 meter die om de percelen is gelegd. Alle waarnemingen die hierin zijn gedaan zijn ook in de dataset vastgelegd. Er is gekozen voor de geringe afstand van 50 meter omdat onderzoeksperceel en controleperceel in sommige gevallen dicht bij elkaar lagen en omdat de trefkans naarmate de afstand toeneemt sterk afneemt.

- Vervolgens is de dataset geëxporteerd naar een rekenblad waarmee door middel van een draaitabel voorkeuren van vogels en zoogdieren per landschapstype en beheerfunctie berekend of afgeleid konden worden.

\section{Wintertellingen}

Doel van de wintertellingen was om een zo goed mogelijke schatting te verkrijgen van aantallen en soorten vogels die 's winters van de percelen gebruik maakten. Tussen 15 oktober en 15 maart van 
het volgende jaar werd op een achttal momenten het totaal aantal vogels per soort dat gebruik maakte van het perceel geteld.

\section{Monitoringsmethode}

- Tussen de telrondes lagen minimaal 10 dagen, gemiddeld is om de twee en halve week een telling gedaan. De tellingen hebben over het algemeen onder gunstige weersomstandigheden plaatsgevonden. Bij periodes met langdurig slecht weer is een beperkt aantal keer onder minder goede omstandigheden geteld.

- Er heeft een transecttelling (Bibby et al., 2000) plaatsgevonden. Het gelopen transect was zo gekozen dat de relatief kleine onderzoekspercelen van ca. twee ha vlakdekkend onderzocht zijn.

- Voor het tellen van de controlepercelen is gebruik gemaakt van volledige akkerbouwpercelen waarbinnen een transect is gelopen dat in grootte vergelijkbaar was met de onderzoekspercelen. Op een kaart is vervolgens een gebied ingetekend in het akkerbouwperceel dat precies zo groot was als het onderzoeksperceel, tellers hadden op die manier een indicatie van de begrenzingen. Binnen de ingetekende begrenzingen zijn alle vogels en zoogdieren geteld precies zoals op de onderzoekspercelen is gedaan.

- Roofvogels en reigers zijn ook geteld indien deze zich ophielden in de directe nabijheid van de onderzoeks- of controlepercelen. Dit is gedaan omdat deze soorten een veel grotere bindingsafstand hebben met hun voedselgebied ten opzichte van de kleinere zangvogels.

\subsubsection{Insecten op onderzoekspercelen en wintergraan}

Tijdens groeiseizoen 2017 is op elk van de 9 bedrijven eenmalig gedurende een week de insectenfauna geteld op:

- het perceel met onderzoeksperceel met aangepaste teelt van zomergraan en

- het controleperceel met gangbaar geteelde winter- of zomergraan.

Doel was om vast te stellen of de percelen een extensievere teelt van zomergraan een andere insectenfauna herbergen dan de controlepercelen gangbaar geteeld wintergraan.

\section{Monitoringsmethode}

- De monitoring van de op de bodem levende insecten werd uitgevoerd met drie potvallen (gedeeltelijk gevuld met water en zeep) per perceel en voor de vliegende insecten werd op elk perceel één gele vangbak (gevuld met glycol) geplaatst. Deze vangbak is geel omdat die kleur een grote aantrekkingskracht op insecten lijkt te hebben.

- De gevangen insecten zijn in het lab gesorteerd in functionele groepen, waarna de aantallen individuen geteld zijn en de biomassa per groep is gewogen.

- Bij de rapportage zijn de insecten ingedeeld in functionele groepen, aantallen en biomassa, vanuit 3 gezichtspunten:

- Insecten als voedsel voor akkervogels

- Insecten als mogelijke schadeveroorzakers in de graanteelt

- Insecten als nuttig in de graanteelt voor plaagonderdrukking.
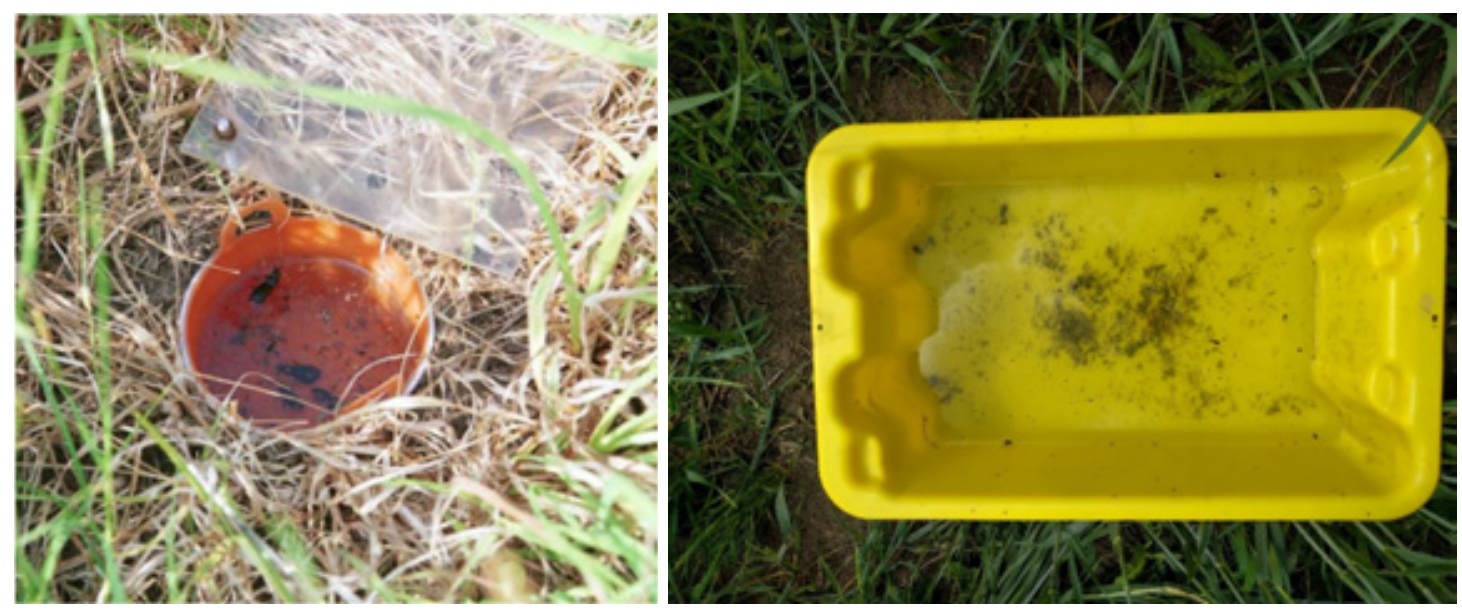

Figuur $3 \quad$ Potval (links) en vangbak (rechts). 


\section{Deelnemende bedrijven en hun bouwplan}

De deelnemende bedrijven liggen als volgt over de provincie verdeeld (zie Figuur 4):

- 3 bedrijven (GM, KdW en HK) Hogeland (lichte kleigrond);

- 3 bedrijven (HEM, BtH en E) Oldambt (zware kleigrond);

- 3 bedrijven (MF, RH en BM) Veenkoloniën (dalgrond).

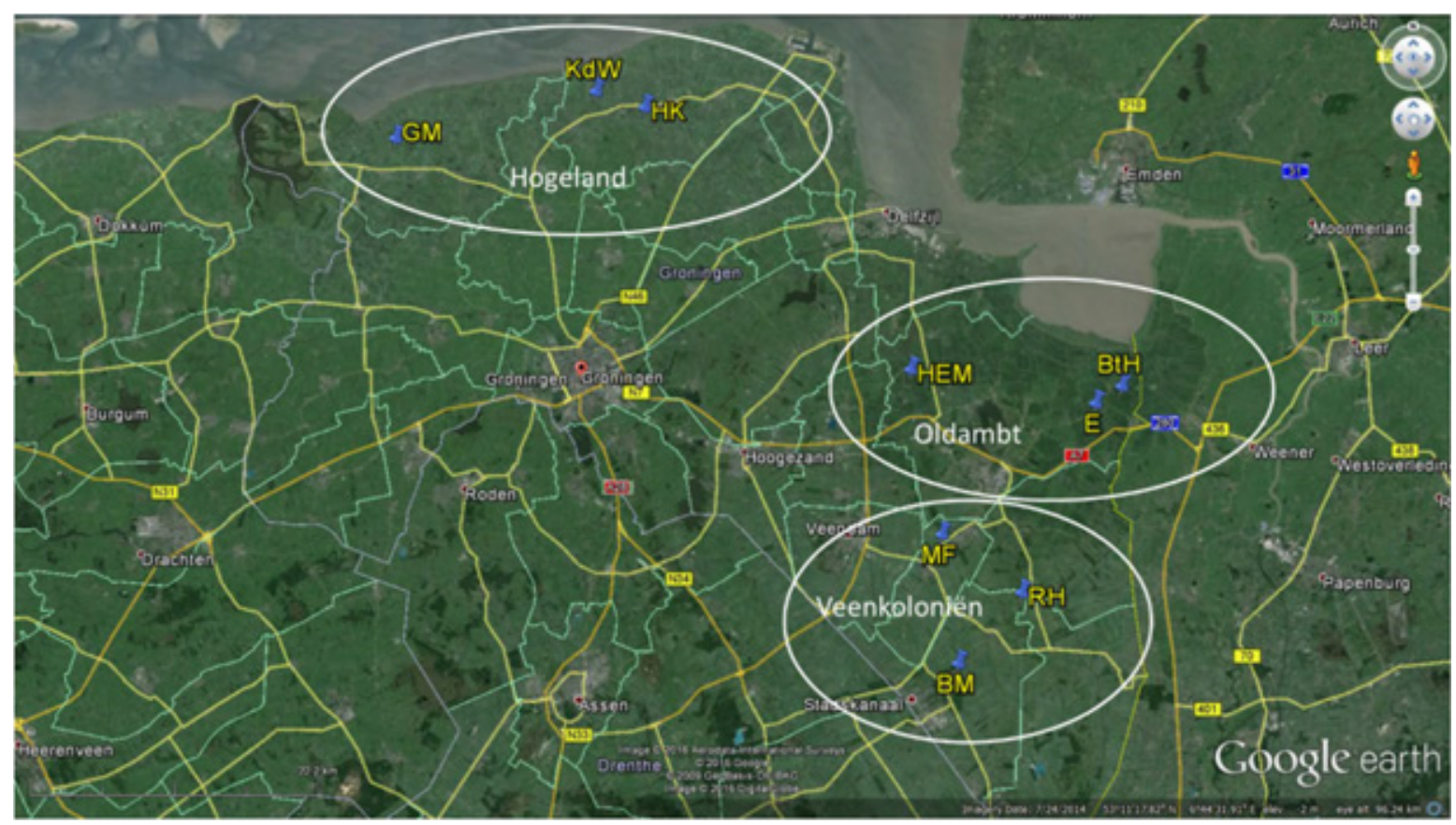

Figuur 4 Ligging van de deelnemende bedrijven in de 3 verschillende regio's.

Tabel 1 Deelnemende bedrijven en pilot- en referentiegewassen zoals die in de periode $2015 \mathrm{t} / \mathrm{m}$ 2017 zijn geteeld.

\begin{tabular}{|c|c|c|c|}
\hline \multirow{2}{*}{\begin{tabular}{|l|}
$2015-2017$ \\
bedrijf
\end{tabular}} & \multirow{2}{*}{$\begin{array}{c}\text { Zomergraan } \\
\text { pilotgewas }\end{array}$} & \multicolumn{2}{|c|}{ Referentiegewassen } \\
\hline & & 1 & 2 \\
\hline \multicolumn{4}{|l|}{ Hogeland } \\
\hline GM & zomertarwe & Wintertarwe & Suikerbieten of aardappelen \\
\hline KdW & zomertarwe & Wintertarwe & Suikerbieten of aardappelen \\
\hline HK & zomertarwe & Wintertarwe & Aardappelen \\
\hline \multicolumn{4}{|l|}{ Oldambt } \\
\hline HEM & zomertarwe & Wintertarwe & Suikerbieten \\
\hline BtH & zomertarwe & Wintertarwe & Suikerbieten \\
\hline $\mathbf{E}$ & zomertarwe & Wintertarwe & Suikerbieten \\
\hline \multicolumn{4}{|c|}{ Veenkoloniën } \\
\hline MF & zomertarwe of -gerst & zomertarwe of -gerst & Aardappelen \\
\hline $\mathbf{R H}$ & zomergerst of haver & Zomergerst & Suikerbieten of aardappelen \\
\hline BM & zomertarwe of -gerst & Zomergerst & Aardappelen \\
\hline
\end{tabular}




\section{Resultaten}

\subsection{Teelt van zomergraan op de onderzoekspercelen}

We hebben de resultaten van 2017 als uitgangspunt genomen omdat dat jaar het meest representatief wordt gezien voor de teelt van zomergranen zoals we die voor ogen hadden met dit praktijkonderzoek. Het eerste jaar 2015 was een aanloopjaar. De werving van de bedrijven kon pas laat in het seizoen plaatsvinden, waardoor op de meeste bedrijven nog niet gewerkt is volgens de voorgestelde richtlijnen van een aangepaste zomergraanteelt. In 2016 hadden een aantal deelnemers de teelt van zomergraan nog niet helemaal in de vingers. Op enkele bedrijven ging er bij de teelt dan ook wat mis. De eerste twee jaren kunnen beschouwd worden als experimenteerfase. Op basis van de ervaringen van deze eerste jaren werd in het derde jaar, 2017, de teelt van zomergraan verder geoptimaliseerd. 


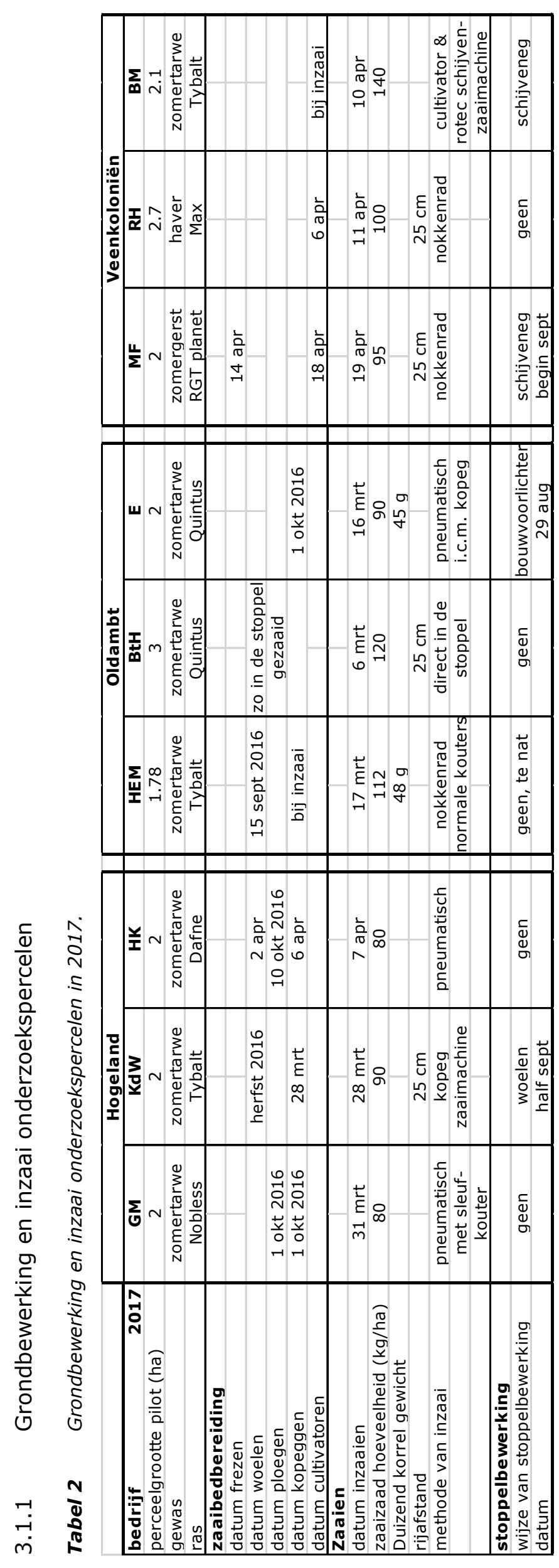

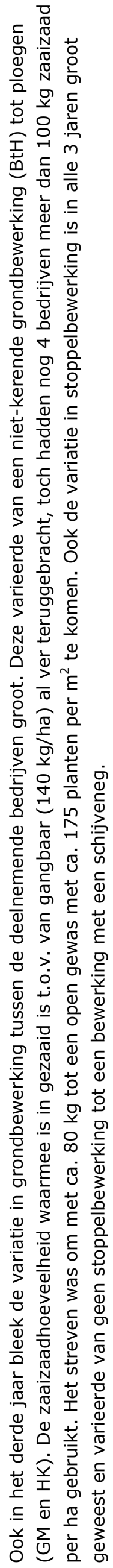




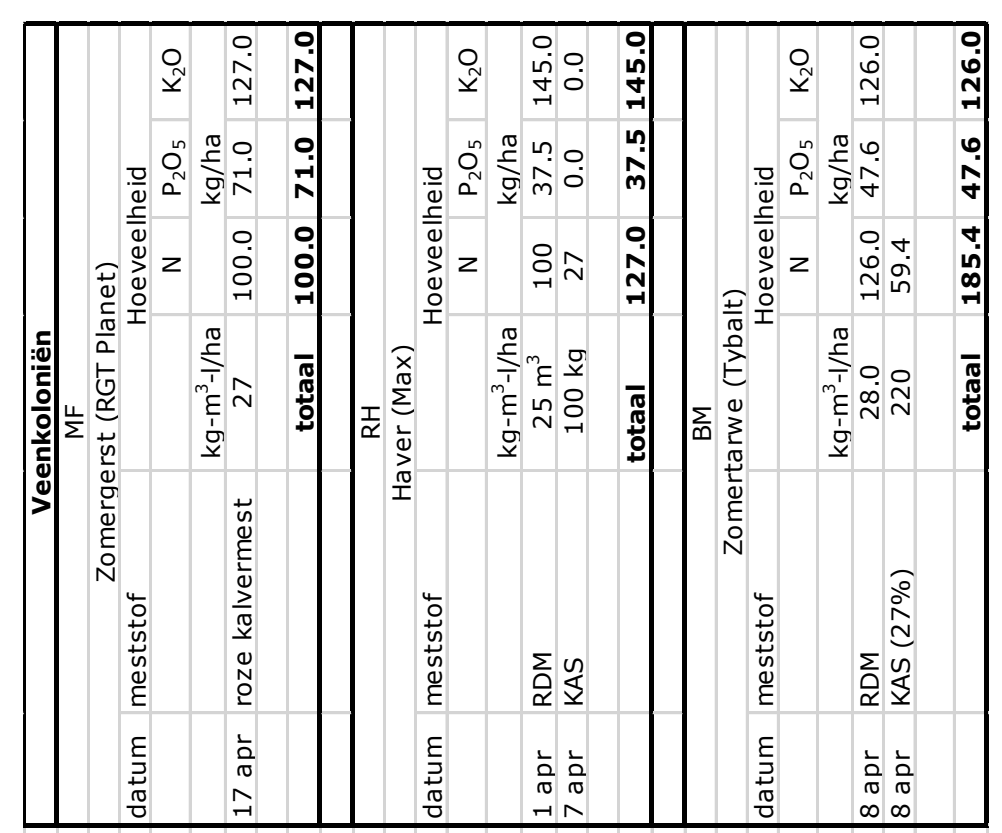

$\infty$

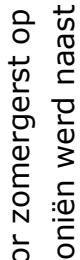

흥 응

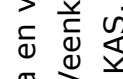

$\stackrel{0}{5}>$

这它

¿

学

윰ํํㄴ 는

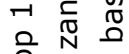

음 음

믈음

屯ै Оิ

范

3 ธิ

을

造

$\stackrel{0}{\searrow}$

खे

敢

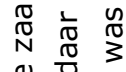

这

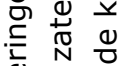

बั

षे एँ

पे

ब

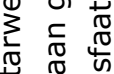

赵

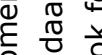

N 0

ㄷำ

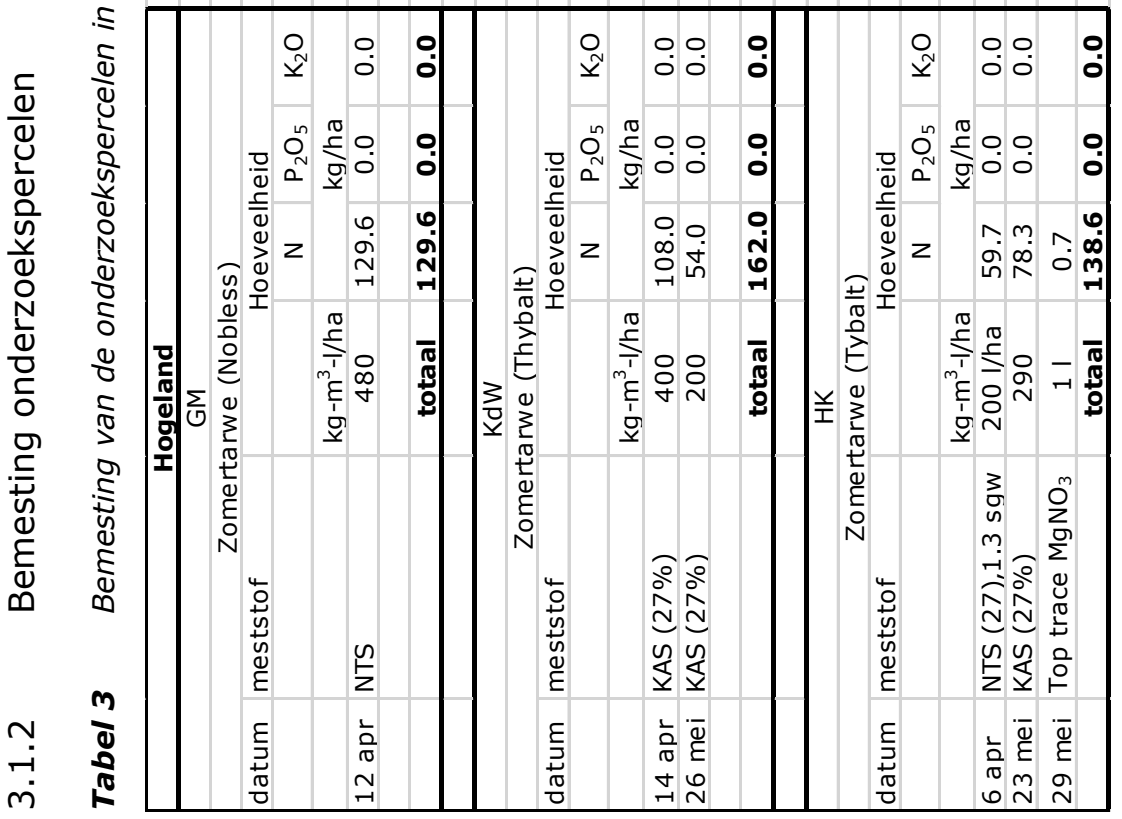

产命恋

으.$\subseteq$

흥 $\frac{\mathrm{U}}{\mathrm{N}}$

$>$ 政

要

过

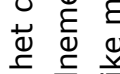

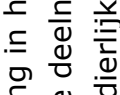

号

पु

है $\varepsilon$

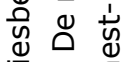

ऐo

这喜 


\subsubsection{Gewasbescherming onderzoekspercelen}

Tabel 4 Herbicide- en fungicidegebruik in 2017 op de onderzoekspercelen met beperkte inzet van gewasbescherming in 2017.

\begin{tabular}{|c|c|c|}
\hline \multicolumn{3}{|c|}{ Hogeland } \\
\hline \multicolumn{3}{|c|}{ GM } \\
\hline \multicolumn{3}{|c|}{ Zomertarwe (Nobless) } \\
\hline datum & middel & dosering \\
\hline & & $\mathrm{kg}-\mathrm{l} / \mathrm{ha}$ \\
\hline $28 \mathrm{mrt}$ & Roundup Ultimate & 2.000 \\
\hline \multirow[t]{2}{*}{17 mei } & Primstar & 1.000 \\
\hline & MCPA & 2.000 \\
\hline \multirow[t]{2}{*}{2 juni } & Skyway & 0.750 \\
\hline & Alternil & 0.400 \\
\hline
\end{tabular}

\begin{tabular}{|l|l|l|}
\hline \multicolumn{3}{|c|}{ Oldambt } \\
\hline \multicolumn{3}{|c|}{ HEM } \\
\multirow{3}{*}{ datum } & Zomertarwe (Tybalt) \\
& middel & dosering \\
\multirow{3}{*}{$15 \mathrm{mrt}$} & kg-l/ha \\
\cline { 2 - 3 } & Glyphogan (glyfosaat) & 3.000 \\
\cline { 2 - 3 } $11 \mathrm{mei}$ & Robbester & 1.000 \\
\cline { 2 - 3 } & MCPA u46 & 2.000 \\
\cline { 2 - 3 } 3 juni & Primstar & 1.500 \\
\cline { 2 - 3 } & Skyway xpro & 1.000 \\
\hline
\end{tabular}

\begin{tabular}{|c|c|c|}
\hline \multicolumn{3}{|c|}{ Veenkoloniën } \\
\hline \multicolumn{3}{|c|}{ MF } \\
\hline \multicolumn{3}{|c|}{ zomergerst (RGT Planet) } \\
\hline datum & middel & dosering \\
\hline & & $\mathrm{kg}-\mathrm{l} / \mathrm{ha}$ \\
\hline \multirow[t]{3}{*}{25 mei } & Tapir & 1.500 \\
\hline & MCPA & 1.500 \\
\hline & Aviator Xpro & 0.750 \\
\hline & & \\
\hline
\end{tabular}

\begin{tabular}{|l|l|c|}
\hline \multicolumn{3}{|c|}{ KdW } \\
\hline \multirow{2}{*}{ datum } & middel & domertarwe (Tybalt) \\
\hline \multirow{3}{*}{2 mei } & & kg-l/ha \\
\cline { 2 - 3 } & Atlantis + 1 I olie & 1.000 \\
\cline { 2 - 3 } & MCPA & 1.500 \\
\cline { 2 - 3 } & Primstar & 1.000 \\
\hline \multirow{2}{*}{ 6 juni } & Tridex DG & 2.000 \\
\hline
\end{tabular}

\begin{tabular}{|ll|c|}
\hline \multicolumn{3}{|c|}{ BtH } \\
datum & Zomertarwe (Quintus) & \\
& & dosering \\
& & $\mathrm{kg}-\mathrm{l} / \mathrm{ha}$ \\
$15 \mathrm{febr}$ & Clinic & 3.000 \\
\hline $19 \mathrm{mei}$ & Tapir & 0.500 \\
\cline { 2 - 3 } & & \\
& & \\
\hline
\end{tabular}

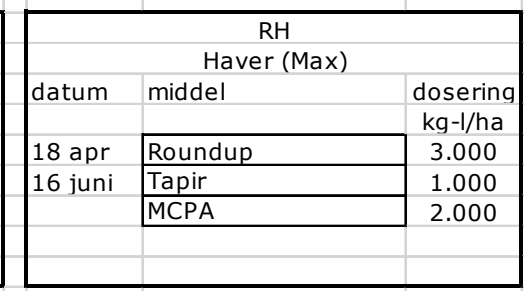

\begin{tabular}{|l|l|c|}
\hline \multicolumn{3}{|c|}{ Zomertarwe (Tybalt) } \\
\hline \multirow{2}{*}{ datum } & middel & dosering \\
& & $\mathrm{kg}-1 / \mathrm{ha}$ \\
$22 \mathrm{mrt}$ & Glyphogan (glyfosaat) & 6.000 \\
\cline { 2 - 3 } $18 \mathrm{mei}$ & Tapir & 1.000 \\
\cline { 2 - 2 } $29 \mathrm{mei}$ & MCPA u 46 m-fluid 500 & 2.000 \\
& Traton & 0.025 \\
\cline { 2 - 3 } & Skyway xpro & 0.750 \\
\cline { 2 - 2 } & Stabilan ccc & 0.750 \\
\hline & Trimaxx & 0.200 \\
\hline & Herbicide \\
\hline & Fungicide \\
\hline & Insecticide \\
\hline & Groeiregulator \\
\hline \multicolumn{2}{|c|}{}
\end{tabular}

\begin{tabular}{|c|c|c|}
\hline \multicolumn{3}{|c|}{$\mathrm{E}$} \\
\hline \multicolumn{3}{|c|}{ Zomertarwe (Quintus) } \\
\hline \multirow[t]{2}{*}{ datum } & middel & dosering \\
\hline & & $\mathrm{kg}-\mathrm{l} / \mathrm{ha}$ \\
\hline \multirow[t]{6}{*}{$10 \mathrm{mei}$} & Traton & 0.030 \\
\hline & Starane Top & 0.200 \\
\hline & Duplosan MCPP & 0.500 \\
\hline & Agrozone MCPA & 2.000 \\
\hline & Balear 720 SC & 1.000 \\
\hline & Stabilan & 0.300 \\
\hline $31 \mathrm{mei}$ & Aviator Xpro & 0.750 \\
\hline
\end{tabular}

\begin{tabular}{|ll|c|}
\hline \multicolumn{3}{|c|}{ BM } \\
datum & \multicolumn{2}{|c|}{ Zomergerst (Thybalt) } \\
\hline \multirow{5}{*}{22 mei } & middel & dosering \\
\cline { 2 - 3 } & Tapir & 1.000 \\
\cline { 2 - 3 } & 46 MCPA & 1.500 \\
\cline { 2 - 3 } & Starane Top & 0.450 \\
\cline { 2 - 3 } & & \\
\hline & & \\
\hline
\end{tabular}

Gewasbescherming op de onderzoekspercelen met zomergraan (Tabel 4) beperkte zich tot herbicide en fungicide gebruik. In vergelijking met gangbaar geteelde wintertarwe (Tabel 5) is het middelengebruik op de onderzoekspercelen beduidend lager. Dit uit zich (Tabel 6) in lagere Milieubelastingspunten (MBP) voor Waterleven in vergelijking met de score in MBP voor Waterleven bij gangbaar geteelde wintertarwe. De hogere MBP-score bij gangbaar geteelde wintertarwe is vooral toe te schrijven aan het insecticidengebruik op een paar bedrijven. Dit resulteert ook in een betere score voor de aangepaste teelt van zomergranen voor Bestuivers en Bestrijders dan bij de gangbaar geteelde wintertarwe. Er worden geen of minder middelen ingezet dit schadelijk zijn voor insecten. Voor Bodemleven verschilt het aantal BMP van de onderzoekspercelen met zomergraan niet van de gangbaar geteelde wintertarwe. Opvallend is dat de aangepaste teelt van zomergraan slechter scoort voor Grondwater. Dit is vrijwel volledig te wijten aan het gebruik van het herbicidemiddel MCPA, een driftgevoelig middel dat slecht scoort in de MBP. Het gebruik van MCPA valt te verklaren door het feit dat er in de gangbare wintertarweteelt meer mogelijkheden zijn met andere middelen. In de gangbare wintertarwe kun je al een herfstbespuiting met een bodemherbicide toepassen. Is dat niet effectief, dan kun je in het voorjaar weer een poging doen. Voor de aangepaste teelt van zomergraan zijn de mogelijkheden en middelen beperkter en worden groeistoffen (MCPA, MCPP en Starane) ingezet voor een zo breed mogelijke werking op de diverse onkruiden. In de Bijlage 2 zijn voor 2017 de MBP per middel per bedrijf gegeven voor gangbaar geteelde wintergranen en voor de onderzoekspercelen met zomertarwe met beperkt gebruik van gewasbeschermingsmiddelen. 
Tabel 5 Herbicide-, insecticide- en fungicidegebruik in 2017 op de referentiepercelen met gangbaar geteelde winter- en zomergranen.

\begin{tabular}{|c|c|c|}
\hline \multicolumn{3}{|c|}{ Hogeland } \\
\hline \multicolumn{3}{|c|}{ GM } \\
\hline \multicolumn{3}{|c|}{ wintertarwe } \\
\hline datum & middel & dosering \\
\hline & & $\mathrm{kg}-\mathrm{l} / \mathrm{ha}$ \\
\hline \multirow[t]{2}{*}{$14 \mathrm{mrt}$} & Fox & 1.250 \\
\hline & Primstar & 1.350 \\
\hline \multirow[t]{3}{*}{5 mei } & Moddus & 0.300 \\
\hline & Skyway & 0.750 \\
\hline & Alternil & 0.700 \\
\hline \multirow[t]{2}{*}{2 juni } & Skyway & 0.750 \\
\hline & Alternil & 0.400 \\
\hline & & \\
\hline & & \\
\hline & & \\
\hline
\end{tabular}

\begin{tabular}{|c|c|c|}
\hline \multicolumn{3}{|c|}{ Oldambt } \\
\hline \multicolumn{3}{|c|}{ HEM } \\
\hline \multicolumn{3}{|c|}{ wintertarwe } \\
\hline datum & middel & dosering \\
\hline & & $\mathrm{kg}-\mathrm{l} / \mathrm{ha}$ \\
\hline 14 nov '16 & Herold sc & 0.600 \\
\hline \multirow[t]{2}{*}{$6 \mathrm{mrt}$} & Glyphogan & 1.259 \\
\hline & Atlantis OD & 1.500 \\
\hline \multirow[t]{2}{*}{$4 \mathrm{apr}$} & Stabilan & 1.000 \\
\hline & Trimaxx & 0.200 \\
\hline $14 \mathrm{apr}$ & Stabilan & 1.000 \\
\hline $10 \mathrm{mei}$ & Seguris & 0.750 \\
\hline \multirow[t]{2}{*}{$29 \mathrm{mei}$} & Ninja & 0.050 \\
\hline & Skyway xpro & 0.800 \\
\hline \multirow{2}{*}{15 juni } & Ninja & 0.050 \\
\hline & Prosaro & 0.800 \\
\hline
\end{tabular}

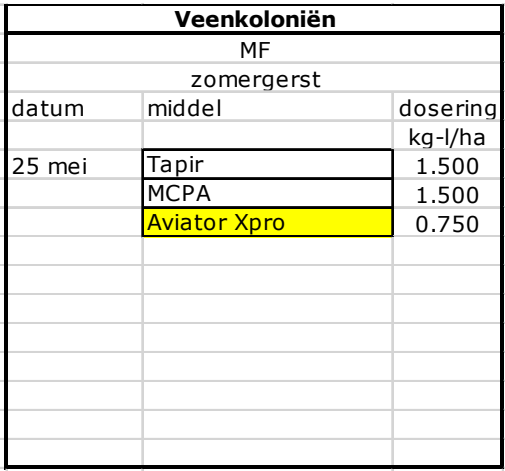

\begin{tabular}{|c|c|c|}
\hline & KdW & \\
\hline & winterta & \\
\hline datum & middel & dosering \\
\hline & & $\mathrm{kg}-\mathrm{l} / \mathrm{ha}$ \\
\hline herfst '16 & Stomp & 3.000 \\
\hline voorjaar & Opus Team & 1.000 \\
\hline april & Tridex DG & 2.000 \\
\hline eind mei & Seguris & 1.000 \\
\hline & & \\
\hline & & \\
\hline
\end{tabular}

\begin{tabular}{|c|c|c|}
\hline \multicolumn{3}{|c|}{ BtH } \\
\hline \multirow{2}{*}{ datum } & middel & dosering \\
\hline & & $\mathrm{kg}-1 / \mathrm{ha}$ \\
\hline 26 sept ' 16 & Clinic & 3.000 \\
\hline \multirow{2}{*}{$15 \mathrm{mrt}$} & Othello & 2.000 \\
\hline & Capri & 0.200 \\
\hline $8 \mathrm{apr}$ & CCC & 1.000 \\
\hline \multirow{3}{*}{$\begin{array}{l}19 \mathrm{apr} \\
10 \mathrm{mei}\end{array}$} & $\overline{\mathrm{CCC}}$ & 1.000 \\
\hline & Adexar & 0.750 \\
\hline & Aviator & 0.750 \\
\hline
\end{tabular}

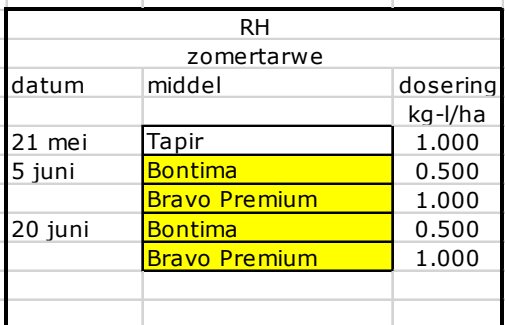

\begin{tabular}{|c|c|c|}
\hline \multicolumn{3}{|c|}{ HK } \\
\hline \multicolumn{3}{|c|}{ wintertarwe } \\
\hline \multirow[t]{2}{*}{ datum } & middel & dosering \\
\hline & & $\mathrm{kg}-\mathrm{I} / \mathrm{ha}$ \\
\hline 26 okt & Herold sc & 0.600 \\
\hline \multirow[t]{3}{*}{$24 \mathrm{apr}$} & dithane dg newtec & 0.600 \\
\hline & Stabilan ccc & 0.750 \\
\hline & Trimaxx & 0.250 \\
\hline \multirow[t]{2}{*}{9 mei } & Seguris & 0.700 \\
\hline & Stabilan ccc & 0.700 \\
\hline \multirow[t]{2}{*}{30 mei } & Ceriax & 2.000 \\
\hline & Ninja & 0.050 \\
\hline \multirow[t]{7}{*}{12 juni } & Ninja & 0.050 \\
\hline & Prosaro & 0.600 \\
\hline & \multirow{2}{*}{\multicolumn{2}{|c|}{ Herbicide }} \\
\hline & & \\
\hline & \multicolumn{2}{|l|}{ Fungicide } \\
\hline & \multicolumn{2}{|l|}{ Insecticide } \\
\hline & \multicolumn{2}{|l|}{ Groeiregulator } \\
\hline & \multicolumn{2}{|c|}{ Hulpstof (emulgeerder) } \\
\hline
\end{tabular}

\begin{tabular}{|c|c|c|}
\hline & $E$ & \\
\hline & wintertarw & \\
\hline datum & middel & dosering \\
\hline & & $\mathrm{kg}-\mathrm{l} / \mathrm{ha}$ \\
\hline $15 \mathrm{mrt}$ & Capri & 0.170 \\
\hline & $\mathrm{CeCeCe}$ & 0.300 \\
\hline & Atlantis OD & 1.500 \\
\hline $10 \mathrm{apr}$ & $\mathrm{CeCeCe}$ & 1.000 \\
\hline $21 \mathrm{apr}$ & Trima $x \mathrm{x}$ & 0.200 \\
\hline & Stabilan & 0.650 \\
\hline 10 mei & Stabilan & 0.300 \\
\hline & Balear 720 SC & 1.000 \\
\hline 20 mei & Manconly 2 & 2.000 \\
\hline $31 \mathrm{mei}$ & Aviator Xpro & 0.750 \\
\hline 13 juni & Prosaro & 0.800 \\
\hline & Balear 720 SC & 1.000 \\
\hline
\end{tabular}

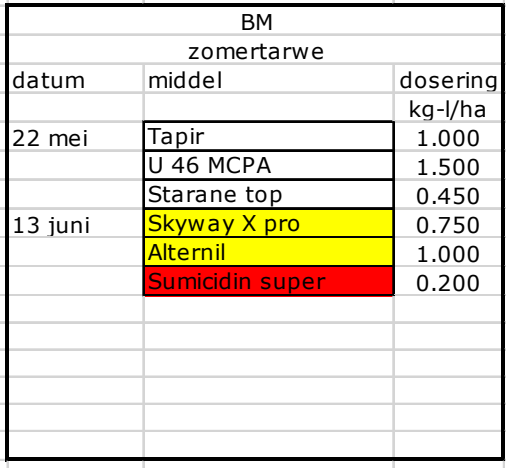

Tabel 6 De Milieubelastingspunten (MBP) volgens de CLM Milieumeetlat (2017) op de zes bedrijven op de klei in Hogeland en Oldambt met referentiepercelen gangbaar geteelde wintertarwe en onderzoekspercelen met zomertarwe met beperkt gebruik van gewasbeschermingsmiddelen.

\begin{tabular}{|c|c|c|c|c|c|}
\hline \multirow{2}{*}{\begin{tabular}{|c|}
2017 \\
Gangbaar geteelde wintertarwe
\end{tabular}} & \multicolumn{3}{|c|}{ BMP } & \multicolumn{2}{|c|}{ Risico voor } \\
\hline & Waterleven & Bodemleven & Grondwater & Bestuivers & Bestrijders \\
\hline Gemiddelde Milieubelastingspunten per ha & 707 & 215 & 191 & $4 \times C$ & $4 \times C$ \\
\hline \multirow[t]{2}{*}{ Totaal Milieubelastingspunten 6 bedrijven } & 4242 & 1290 & 1145 & $17 \times B$ & $3 \times B$ \\
\hline & & & & $25 \times A$ & $17 \times A$ \\
\hline \multicolumn{6}{|l|}{ Aangepaste teelt zomertarwe } \\
\hline Gemiddelde Milieubelastingspunten per ha & 288 & 223 & 931 & $20 \times A$ & $8 \times A$ \\
\hline Totaal Milieubelastingspunten 6 bedrijven & 1729 & 1335 & 5588 & $8 \times B$ & $1 \times B$ \\
\hline \multicolumn{6}{|c|}{$A=$ Bruikbaar zonder risico's voor insecten (bestuivers en bestrijders) } \\
\hline \multicolumn{6}{|c|}{$B=$ Beperkt bruikbaar met enige risico's voor insecten (bestuivers en bestrijders) } \\
\hline \multicolumn{6}{|c|}{ C = Niet bruikbaar zonder risico's voor insecten (bestuivers en bestrijders) } \\
\hline
\end{tabular}




\subsubsection{Gewasopbrengst en kwaliteit graan onderzoekspercelen}

Tabel 7 De korrelopbrengsten en gemeten kwaliteit van de korrel van zomergranen in $2015 \mathrm{t} / \mathrm{m}$ 2017. In grijs de opbrengst en kwaliteit van zomergraan die geteeld werd in een aanvullende proef op Regionaal proefbedrijf Ebelsheerd in 2017.

\begin{tabular}{|c|c|c|c|c|c|c|c|c|c|c|c|}
\hline \multicolumn{4}{|c|}{ Opbrengst zomergraan ton/ha } & \multicolumn{8}{|c|}{ Kwaliteit zomertarwe 2015-2017 } \\
\hline zomertarwe & 2015 & 2016 & 2017 & \multicolumn{2}{|c|}{ eiwit \% } & \multicolumn{2}{|c|}{ zetmeel\% } & \multicolumn{2}{|c|}{$\mathrm{HL}$} & \multicolumn{2}{|c|}{ Zeleny } \\
\hline zomergerst & & & & gemid. & st dev. & gemid. & st dev. & gemid. & st dev. & gemid. & st dev. \\
\hline haver & \multicolumn{11}{|c|}{ Hogeland lichte klei } \\
\hline GM & 6.5 & 2.0 & 7.5 & 12.7 & 1.7 & 60.3 & 0.6 & 71.7 & 5.2 & 47.7 & 11.8 \\
\hline KdW & 6.7 & 5.5 & 4.2 & 12.7 & 1.1 & 58.6 & 1.8 & 60.7 & 9.8 & 35.0 & 7.5 \\
\hline $\mathrm{HK}$ & 6.6 & 1.2 & 4 & 12.5 & 1.3 & 56.3 & 1.2 & 56.6 & 3.3 & 27.3 & 5.5 \\
\hline \multicolumn{12}{|c|}{ Oldambt zware klei } \\
\hline HEM & 6.8 & 2.3 & 4.5 & 11.9 & 0.5 & 60.7 & 0.4 & 70.4 & 2.6 & 42.0 & 1.7 \\
\hline BtH & 7.4 & 6.4 & 6.2 & 12.0 & 0.5 & 61.3 & 0.9 & 72.1 & 3.7 & 41.7 & 2.3 \\
\hline $\mathrm{E}$ & 7.3 & 7.3 & 7.3 & 12.2 & 0.8 & 61.0 & 1.5 & 71.3 & 0.1 & 42.3 & 14.0 \\
\hline \multicolumn{12}{|c|}{ Veenkoloniën dalgrond (zand) } \\
\hline MF & 6.5 & 3.6 & 5.7 & 13.6 & 1.0 & 58.7 & 1.8 & 67.9 & 3.8 & 53.5 & 9.2 \\
\hline RH & 6.2 & 3.5 & 3.4 & - & - & - & - & - & - & - & - \\
\hline BM & 5.5 & 3.3 & 4.8 & - & - & - & - & - & - & - & - \\
\hline \multicolumn{12}{|c|}{ Zaaidichtheidsproef Ebelsheerd 2017} \\
\hline zaaidichtheic & $175 \mathrm{za}$ & $\mathrm{den} / \mathrm{m}^{2}$ & 9.2 & 12.9 & 0.3 & 62.0 & 0.4 & 72.8 & 2.6 & 42.5 & 0.5 \\
\hline
\end{tabular}

De korrelopbrengsten waren in het eerste jaar 2015 met gemiddeld 6.9 ton/ha voor zomergraan op klei en 6.1 ton/ha op zandgrond het beste, maar niet representatief voor een aangepaste teelt van zomergraan zoals beoogd in deze prakrijkproef. In dat jaar waren de zaaizaadhoeveelheden en bemesting aanzienlijk hoger dan in de latere jaren. Daarentegen was 2016 een slecht jaar en lagen de gemiddelde opbrengsten voor zomergraan op klei en zand op resp. 4.1 en 3.5 ton/ha. Het derde jaar lijkt het meest representatief omdat de meeste deelnemers de teelt van zomergraan goed in de vingers begonnen te krijgen. Bemesting, grondbewerking en zaaidichtheid werden na 2 jaar ervaring verder geoptimaliseerd. Voor een aangepaste teelt van zomergraan op klei lijkt een opbrengst van 6 ton/ha reëel. Voor zand lijkt een opbrengst 5 ton per ha haalbaar.

Op proefveldschaal is bij een zaaizaaddichtheid van 175 zaden per $\mathrm{m}^{2}$ op klei een opbrengst van ruim 9 ton haalbaar. Dit laten de resultaten zien van een aanvullende proef met zomergraan met verschillende zaaidichtheden op Regionaal proefbedrijf Ebelsheerd (SPNA) in 2017 (zie Bijlage 3). In deze proef zijn bemesting, gebruik gewasbescherming en grondbewerking gelijk aan die van de teelt van zomertarwe op het onderzoeksperceel, elders op Ebelsheerd.

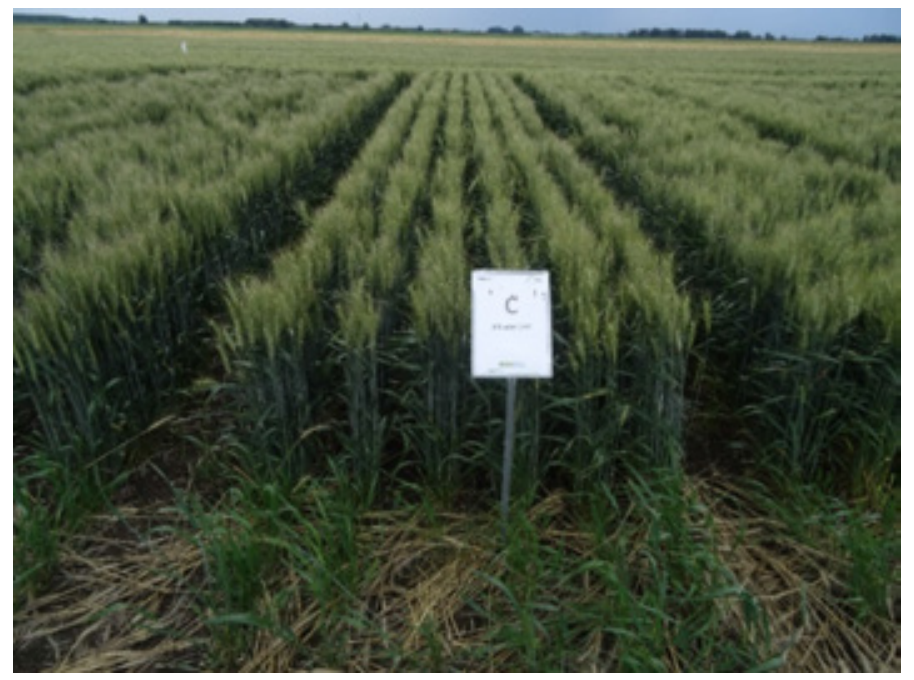

Figuur 5 Veldproef op Ebelsheerd met verschillende zaaizaaddichtheden. 
In Tabel 7 is de graanopbrengst en de kwaliteit van de korrel weergegeven voor zomertarwe, ingezaaid met 175 zaden per $\mathrm{m}^{2}$. Doordat deze proef is aangelegd op een homogeen stuk van het bedrijf onder optimale teeltomstandigheden en zonder wendakkers e.d. lag de opbrengst bij gelijke bemesting, zaaidichtheid en gewasbescherming 2 ton hoger dan op het praktijkperceel op dit bedrijf, waar de opbrengst 7.3 ton per ha was. In kwaliteit scoorde het graan uit deze proef ook net iets beter dan het graan van het onderzoeksperceel en ook wat beter dan het geoogste graan op de andere bedrijven. Ebelsheerd wist 3 jaar lang jaarlijks 7.3 ton per ha te oogsten en presteerde daarmee het best en meest constant in vergelijking met de andere deelnemers. Alleen het bedrijf van GM scoorde in 2017 met 7.5 ton/ha wat hoger, maar dit betrof een eerstejaars onderzoeksperceel (de eerste 2 jaren fungeerde een ander perceel als onderzoeksperceel) en was daarom niet vergelijkbaar met de andere praktijkpercelen waar voor het derde jaar achtereen zomergraan werd geteeld.

In het voorjaar van 2016 zijn op 7 onderzoekspercelen tellingen uitgevoerd naar de spruitdichtheid. In Figuur 6 zijn deze per bedrijf voor zomertarwe tegen de inzaaihoeveelheid uitgezet. Het voorstel was om tot 175 planten per $\mathrm{m}^{2}$ te komen. De tellingen laten zien dat bij een zaaizaadhoeveelheid van 80 tot $100 \mathrm{~kg}$ per ha tussen de 100 en 120 spruiten per $\mathrm{m}^{2}$ werden gerealiseerd. Dat was aanzienlijk minder dan de beoogde 175 planten per $\mathrm{m}^{2}$.

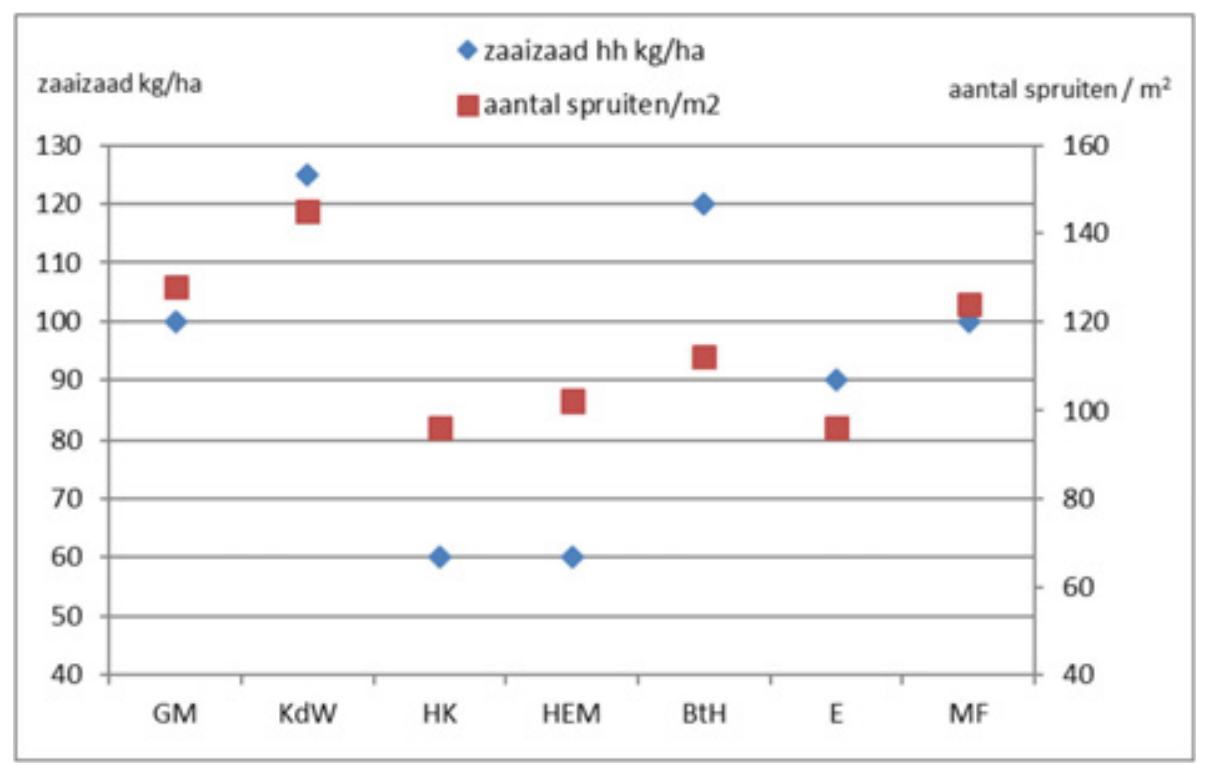

Figuur 6 Het aantal getelde spruiten per $\mathrm{m}^{2}$ in relatie tot de hoeveelheid ingezaaide zomertarwe in 2016.

\subsubsection{Teelt op de referentiepercelen}

De referentiegewassen op de kleigronden van het Hogeland en Oldambt zijn wintertarwe, aardappelen en suikerbieten en op de lichtere gronden in de Veenkoloniën zomergerst of zomertarwe en aardappelen. De teelten zijn gangbaar uitgevoerd op een wijze die voor het betreffende bedrijf gebruikelijk is. Gegevens over bemesting, grondbewerking, gewasbescherming en gewasopbrengsten zijn beschikbaar maar worden in dit rapport verder niet besproken. Deze waarnemingen waren vooral bedoeld om eventuele bijzonderheden in onkruidontwikkeling en vogelaantallen te kunnen verklaren. 


\subsection{Ontwikkeling onkruiddruk 2015-2017}
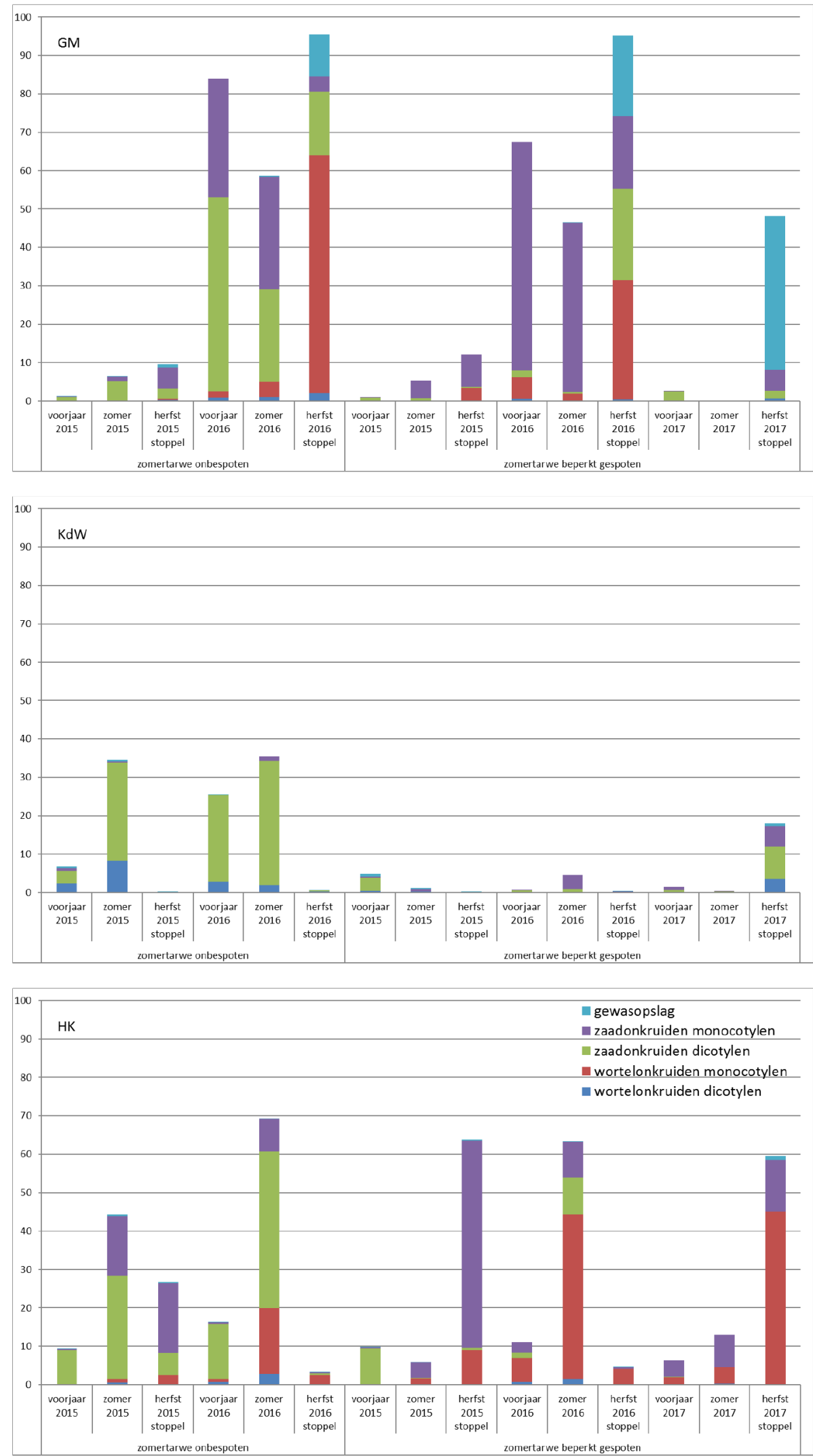

Figuur 7 De bedekkingspercentages van zaad- en wortelonkruiden en gewasopslag per waarnemingsronde voor de onderzoekspercelen en de daarop volgende stoppel op de bedrijven in het Hogeland. 

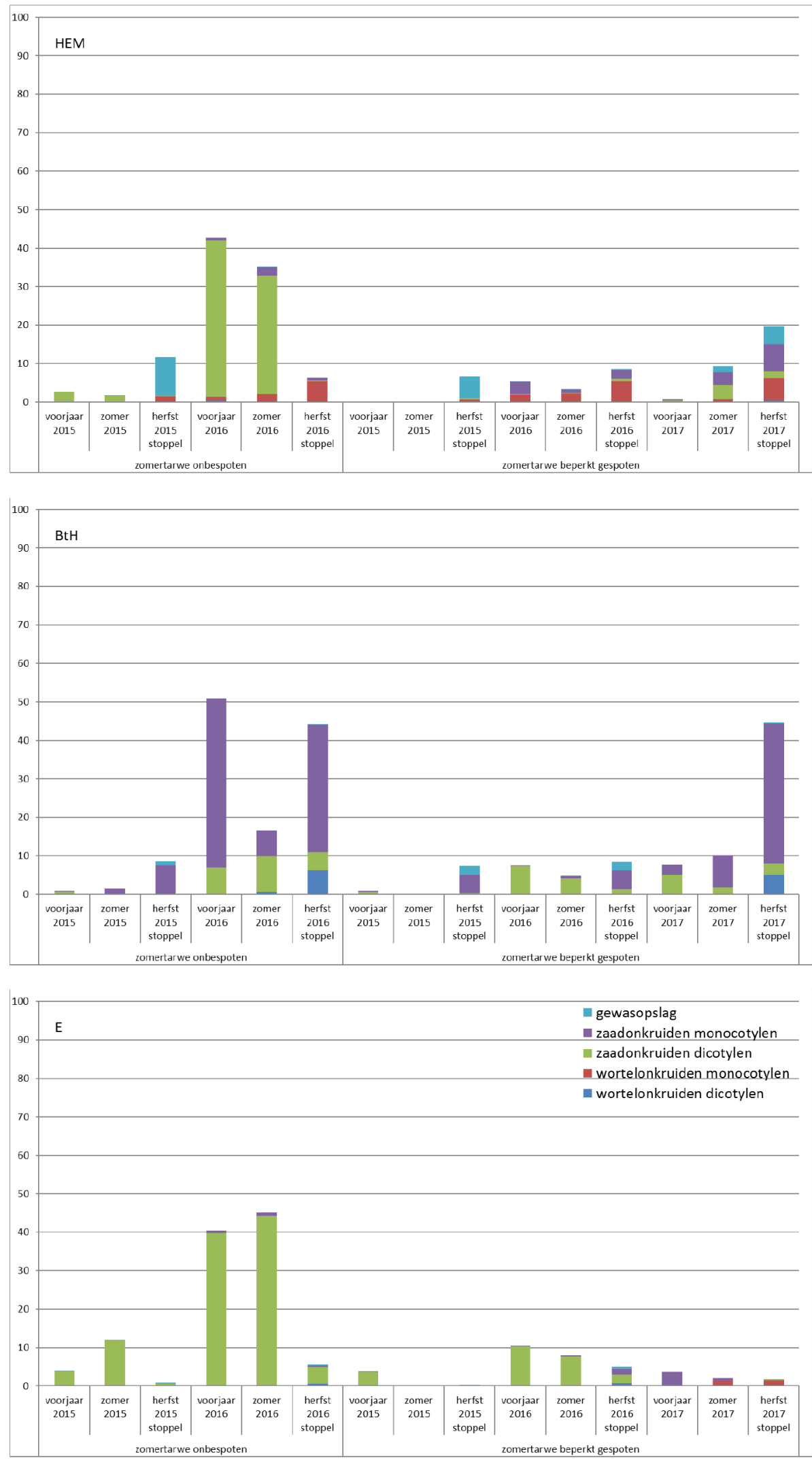

Figuur 8 De bedekkingspercentages van zaad- en wortelonkruiden en gewasopslag per waarnemings-ronde voor de onderzoekspercelen en de daarop volgende stoppel op de bedrijven in het Oldambt. 

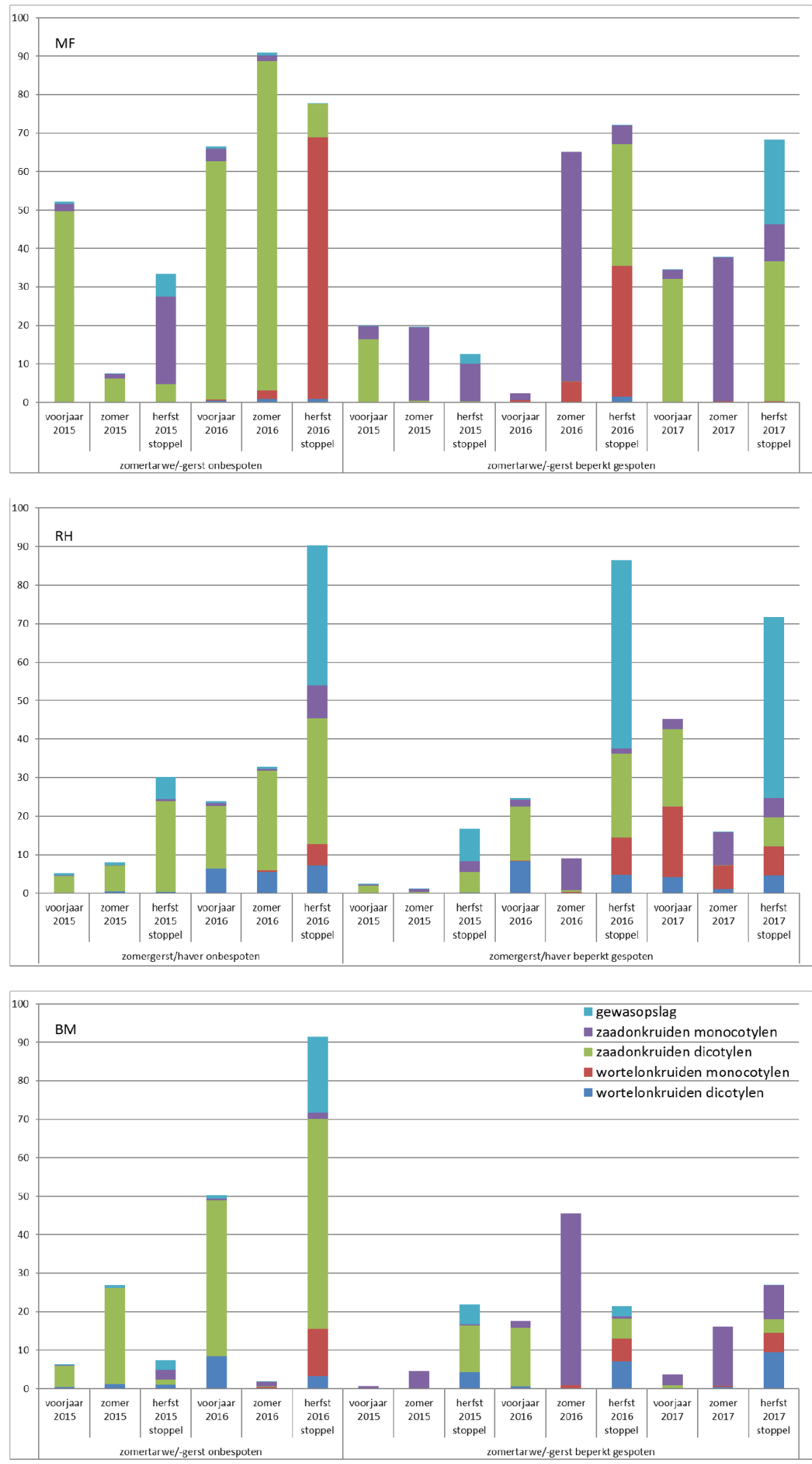

Figur 9 De bedekkingspercentages van zaad- en wortelonkruiden en gewasopslag per waarnemings-ronde voor de onderzoekspercelen en de daarop volgende stoppel van de bedrijven in de Veenkoloniën. 


\subsubsection{Percelen zonder gebruik van gewasbeschermingsmiddelen}

In de Figuren 7 t/m 9 zijn voor de drie regio's per bedrijf de resultaten van de onkruidontwikkeling weergegeven gedurende de proefperiode $2015 \mathrm{t} / \mathrm{m}$ 2017. De onkruidvegetatie is in 5 klassen verdeeld: zaadonkruiden (monocotylen $=$ grasachtigen en dicotylen $=$ kruiden en vlinderbloemingen) en wortelonkruiden (monocotylen en dicotylen). Daarnaast is gewasopslag als aparte groep onderscheiden. In Bijlage 1 is een totaallijst opgenomen van alle aangetroffen akkeronkruiden ingedeeld in deze 5 klassen.

Op een beperkt areaal (circa $40 \mathrm{~m}$ x $40 \mathrm{~m}$ ) van de pilotpercelen zijn in 2015 en 2016 helemaal geen gewasbeschermingsmiddelen toegediend (hierbij moet de opmerking geplaatst worden dat op het bedrijf BM in juni 2016 door een misverstand wel gespoten is met een herbicide, hetgeen een vertekend beeld geeft voor de onkruiddruk in de zomerronde van 2016). In het $2^{\mathrm{e}}$ jaar werd al duidelijk dat niet spuiten (de behandeling onbespoten in de Figuren 7, 8 en 9) geen praktische optie zou zijn en werd besloten deze variant niet voort te zetten in het derde jaar 2017. De onkruiddruk op het onbespoten perceelsgedeelte was enorm en onhoudbaar. Op de klei in het Hogeland en Oldambt ging het vooral om kamille, duizendknoopsoorten als varkensgras, perzikkruid, zwaluwtong en beklierde duizendknoop, melkdistelsoorten als gekroesde- en akkermelkdistel en verder uitstaande melde, melganzenvoet, krodde en klein kruiskruid. Op sommige bedrijven zoals bij HK vormde het wortelonkruid kweek een probleem en bij BtH duist. Het onkruidprobleem op zandgrond was over de hele linie gezien nog groter dan op de klei. Ook hier waren het de duizendknoopsoorten zoals varkensgras, perzikkruid en zwaluwtong, melkdistelsoorten als gekroesde- en akkermelkdistel en verder, melganzenvoet en klein kruiskruid die het probleem vormden. Maar in tegenstelling tot de kleigebieden vormden vooral een aantal gebiedspecifieke soorten van zandgronden zoals straatgras, vogelmuur, knopkruid, bijvoet, ridderzuring, brandnetel en zwarte nachtschade een groot probleem. Op sommige bedrijven op zandgrond zoals bij MF ging het wortelonkruid kweek sterk overheersen. Onderstaande foto's (Figuur 10) laten een impressie zien van de onkruiddruk in juni op de onbespoten delen in resp. Hogeland (HK), Oldambt (E) en Veenkoloniën (MF). Waarbij op het bedrijf HK vooral kamille en perzikkruid een probleem vormde, bij $E$ varkensgras en witte krodde en bij MF zwaluwtong en melganzevoet.

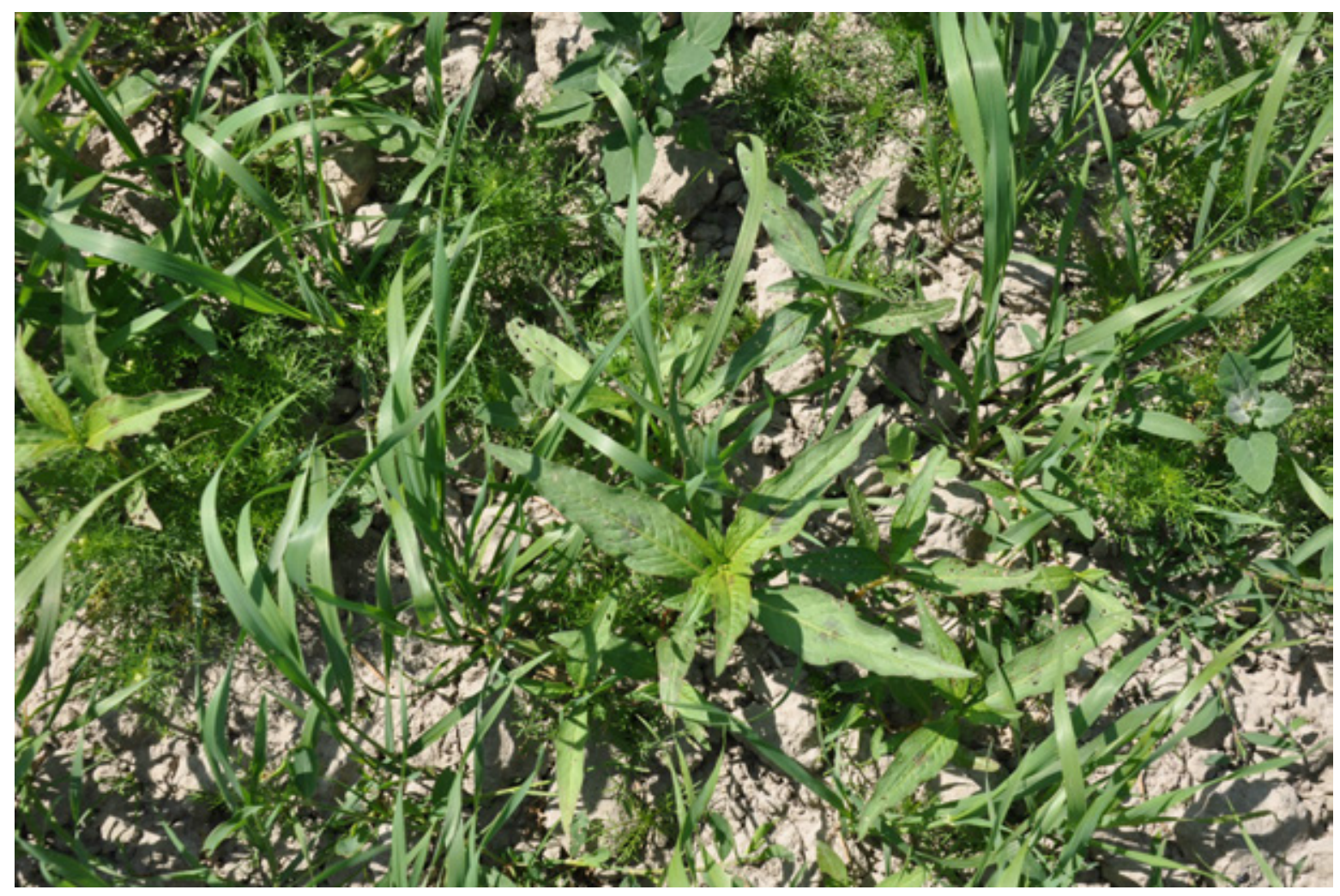



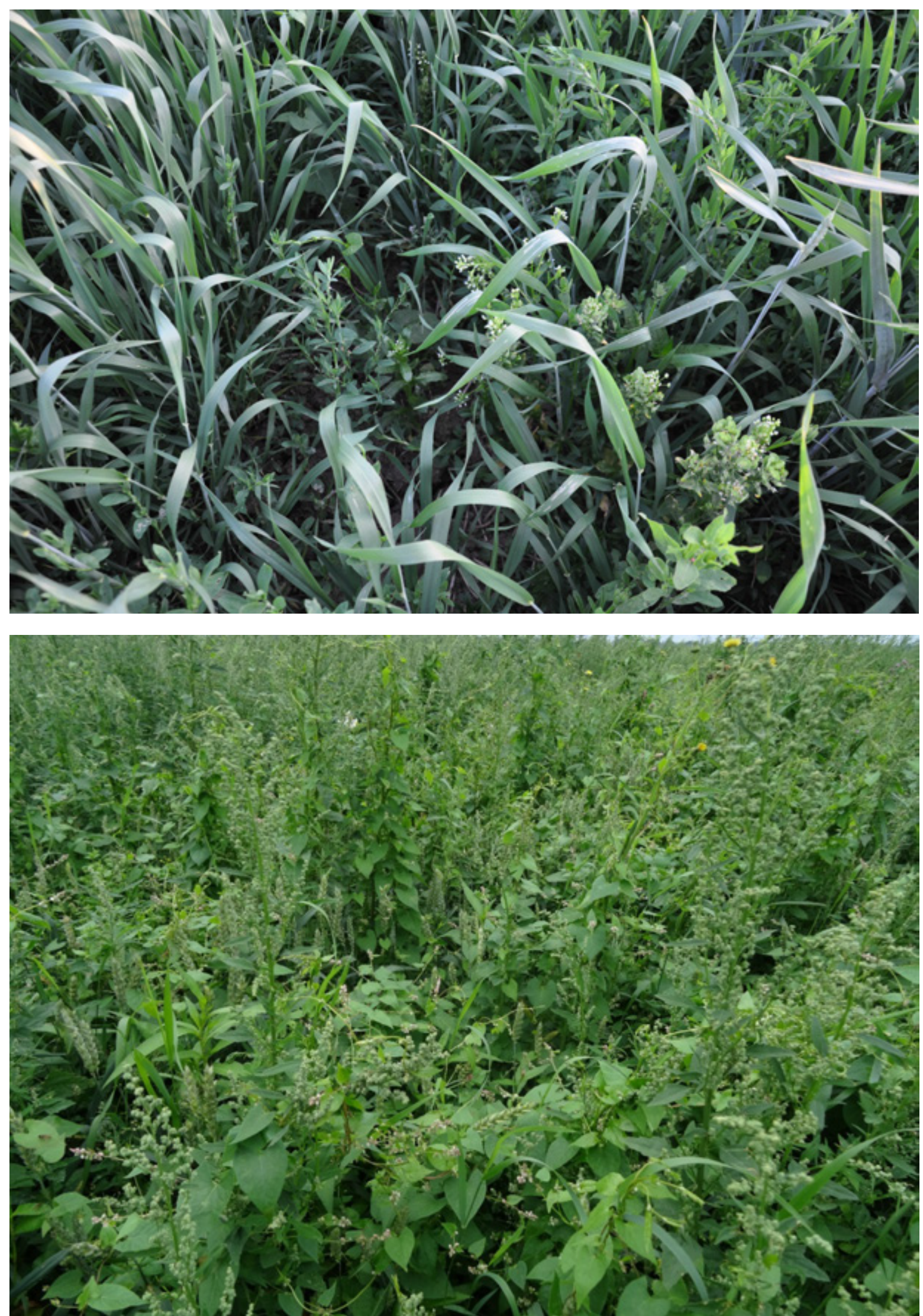

Figuur 10 Een impressie van de onkruiddruk in de onbespoten zomergranen in de 3 regio's (van boven naar beneden: Hogeland, Oldambt en Veenkoloniën). 


\subsubsection{Percelen met beperkte inzet van gewasbeschermingsmiddelen}
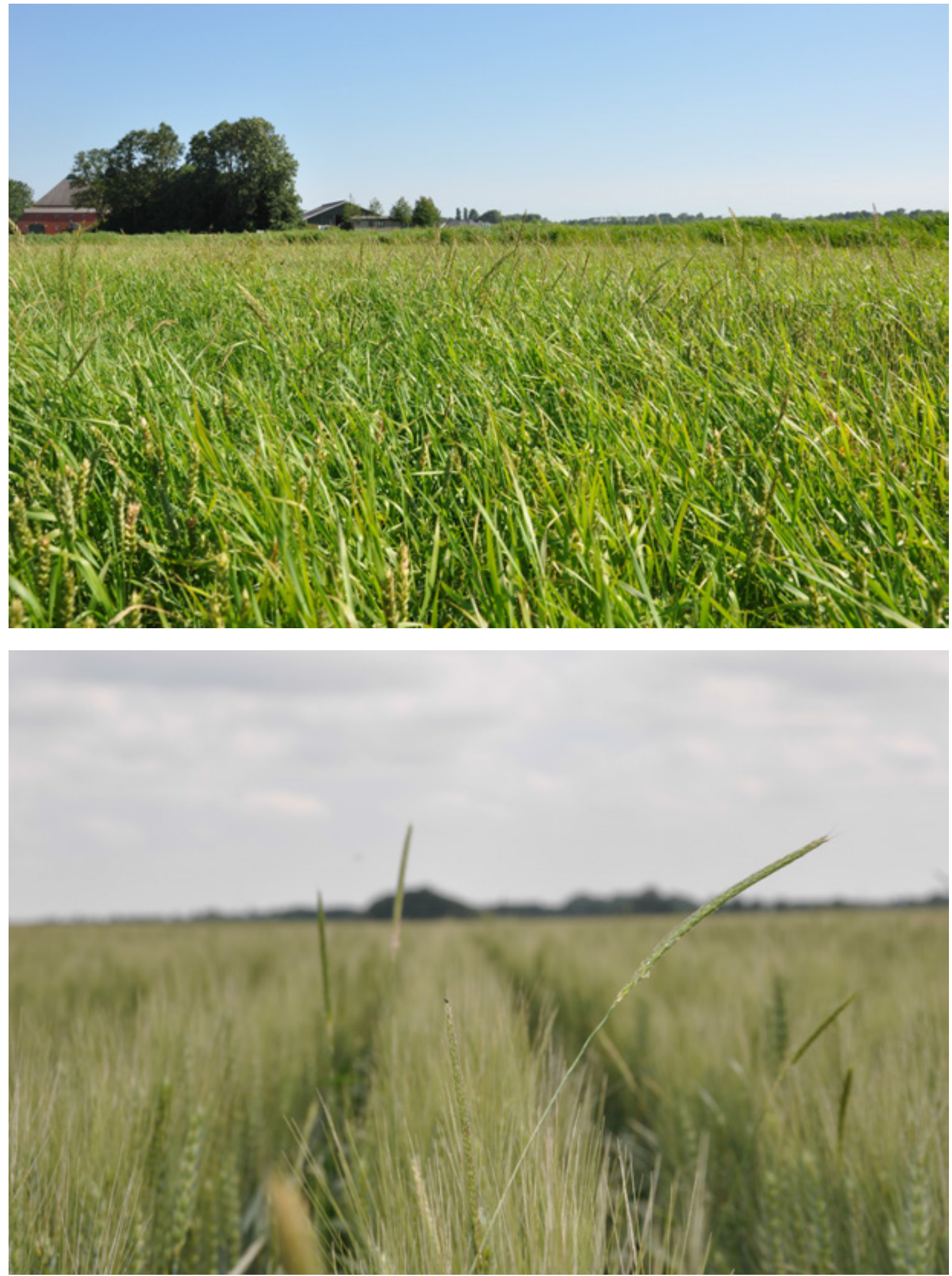


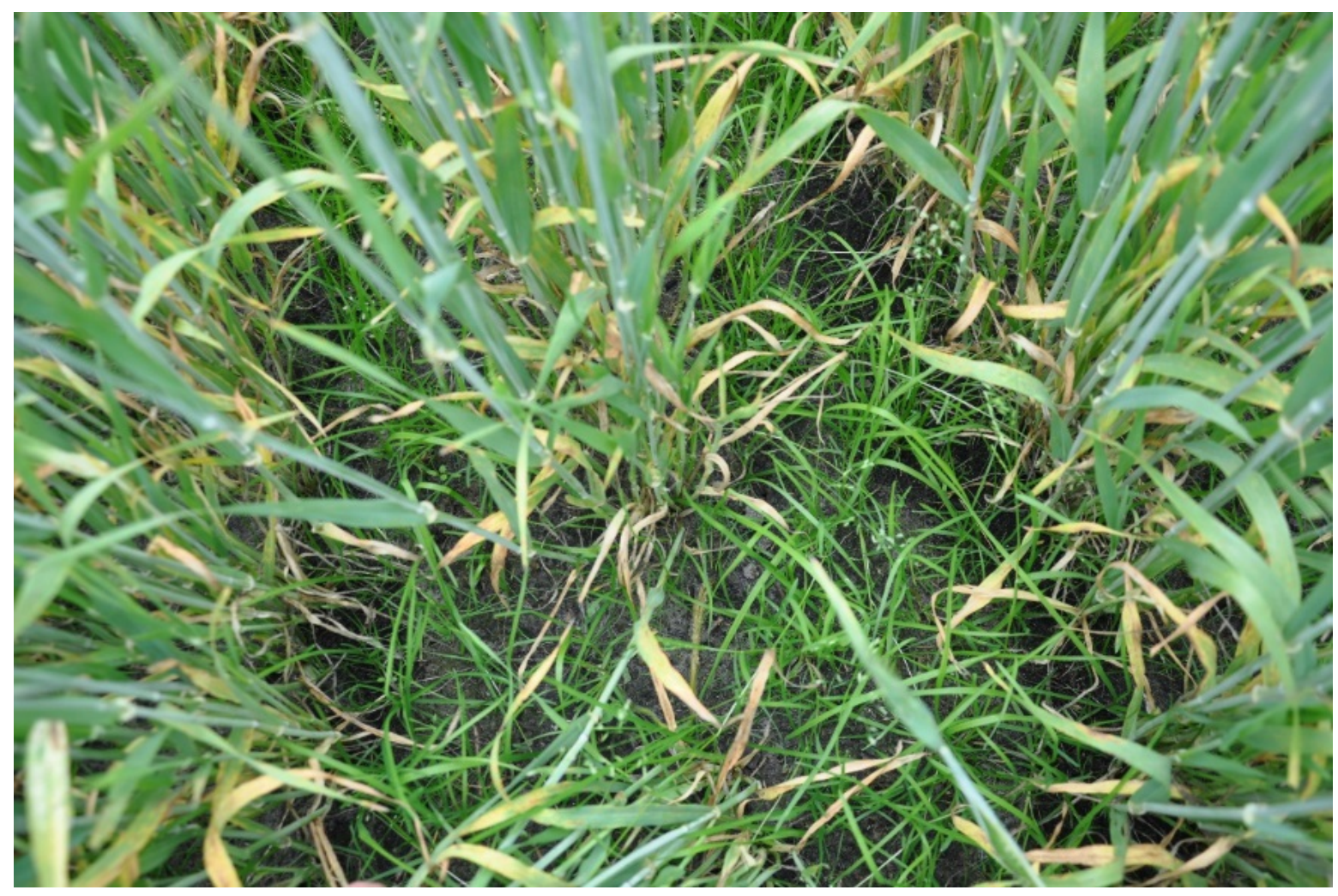

Figuur 11 Probleemgrassen resp. kweek (HK Hogeland), duist (BtH Oldambt) en straatgras (MF Veenkoloniën).

Voor een beperkte inzet van herbiciden in de zomer, meestal in de maanden mei en juni, kunnen alleen middelen gebruikt worden die geen schade toebrengen aan de zomergranen. Het zijn middelen die alleen dicotylen bestrijden, in 2017 was dat in de meeste gevallen het middel MCPA. De hoeveelheid akkeronkruiden is in de zomer dan ook beperkt. Doordat de gebruikte middelen selectief zijn voor dicotylen, zien we op de onderzoekspercelen met beperkte inzet van herbiciden een toename van grassen. In de meeste gevallen is dat straatgras, maar ook kweek, duist en een aantal andere grassen. De foto's in Figuur 11 illustreren dat. Vooral een meerjarig wortelonkruid als kweek kan een probleem gaan vormen en is een niet gewenste ontwikkeling. Er waren twee bedrijven (HK en MF) waar dit echt een probleem vormde. Het gevolg was dat de betreffende deelnemers hebben ingegrepen door de kweek met glyfosaat te behandelen in najaar 2016 (MF) of voorjaar 2017 (HK). Ook duist is vrijwel alleen te bestrijden $(\mathrm{BtH})$ door het met glyfosaat 'af te branden' in het vroege voorjaar.

In Tabel 8 zijn de belangrijkste akkeronkruiden (met $>5 \%$ bedekking) weergegeven die gedurende de onderzoeksperiode in zowel de onbespoten zomergranen als de zomergranen met beperkte inzet van gewasbeschermingsmiddelen zijn waargenomen. Hier komt duidelijk naar voren dat de lichtere zandgrond in de Veenkoloniën een eigen kenmerkende onkruidvegetatie kent. Soorten als hanepoot, knopkruid, vogelmuur, zwarte nachtschade, bijvoet, grote brandnetel en ridderzuring zijn echte soorten van het zand. In deze tabel is ook aangeven welke soorten op moment van waarnemen zaad droegen. Dit in verband met verdere uitzaai (opkomst na de oogst in de stoppel) en als mogelijke voedselbron voor akkervogels. 
Tabel 8 De in de proefperiode belangrijkste akkeronkruiden (bedekking > 5\%) in de 3 verschillende regio's.

\begin{tabular}{|l|l|c|c|c|}
\hline \multirow{2}{*}{$\begin{array}{l}\text { één- of meerjarige zaadonkruiden } \\
\text { monocotylen }\end{array}$} & \multicolumn{3}{|c|}{ met $>5 \%$ bedeking } \\
\cline { 3 - 5 } & Alopecurus myosuroides & Hogeland & Oldambt & Veenkoloniën \\
\hline duist & Echinochloa crus-galli & & $\mathrm{X}$ & \\
\hline hanepoot & Poa annua & $\mathrm{X}$ & $\mathrm{X}$ & $\mathrm{X}$ \\
\hline zachter dravik & Bromus hordeaceus & & $\mathrm{X}$ & \\
\hline dicotylen & & & & \\
\hline akkerereprijs & Veronica agrestis & $\mathrm{X}$ & $\mathrm{X}$ & $\mathrm{X}$ \\
\hline akkervergeet-mij-nietje & Myosotis arvensis & & $\mathrm{X}$ & \\
\hline beklierde duizendknoop & Persicaria lapathifolia & $\mathrm{X}$ & $\mathrm{X}$ & \\
\hline echte kamille & Matricaria recutita & $\mathrm{X}$ & $\mathrm{X}$ & \\
\hline gekroeste melkdistel & Sonchus asper & $\mathrm{X}$ & $\mathrm{X}$ & $\mathrm{X}$ \\
\hline gewone duivenkervel & Fumaria officinalis & & $\mathrm{X}$ & \\
\hline gewoon varkensgras & Polygonum aviculare & $\mathrm{X}$ & $\mathrm{X}$ & \\
\hline hoenderbeet & Lamium amplexicaule & $\mathrm{X}$ & $\mathrm{X}$ & \\
\hline hondspeterselie & Aethusa cynapium & & $\mathrm{X}$ & \\
\hline kleefkruid & Galium aparine & $\mathrm{X}$ & $\mathrm{X}$ & \\
\hline klein kruiskruid & Senecio vulgaris & $\mathrm{X}$ & $\mathrm{X}$ & $\mathrm{X}$ \\
\hline knopkruid & Galinsoga & & & $\mathrm{X}$ \\
\hline melganzevoet & Chenopodium album & $\mathrm{X}$ & $\mathrm{X}$ & $\mathrm{X}$ \\
\hline paarse dovenetel & Lamium purpureum & & $\mathrm{X}$ & \\
\hline perzikkruid & Persicaria maculosa & $\mathrm{X}$ & $\mathrm{X}$ & $\mathrm{X}$ \\
\hline uitstaande melde & Atriplex patula & $\mathrm{X}$ & $\mathrm{X}$ & \\
\hline vogelmuur & Stellaria media & & & $\mathrm{X}$ \\
\hline witte krodde & Thlaspi arvense & $\mathrm{X}$ & $\mathrm{X}$ & \\
\hline zwaluwtong & Fallopia convolvulus & $\mathrm{X}$ & $\mathrm{X}$ & $\mathrm{X}$ \\
\hline zwarte nachtschade & Solanum nigrum & & & $\mathrm{X}$ \\
\hline
\end{tabular}

\begin{tabular}{|c|c|c|c|c|}
\hline \multirow{2}{*}{\multicolumn{2}{|c|}{\begin{tabular}{|l|} 
meerjarige wortelonkruiden of \\
onkruiden met uitlopers
\end{tabular}}} & \multicolumn{3}{|c|}{ met $>5 \%$ bedekking } \\
\hline & & \multirow[t]{2}{*}{ Hogeland } & \multirow[t]{2}{*}{ Oldambt } & \multirow[t]{2}{*}{ Veenkoloniën } \\
\hline monocotylen & & & & \\
\hline Engels raaigras & Lolium perenne & $\mathrm{x}$ & $\mathrm{x}$ & \\
\hline fioringras & Agrostis stolonifera & $\mathrm{x}$ & & $\mathrm{x}$ \\
\hline gestreepte witbol & Holcus lanatus & & & $\mathrm{x}$ \\
\hline kropaar & Dactylis glomerata & $\mathrm{x}$ & & \\
\hline kweek & Elytrigia repens & $\mathrm{x}$ & $\mathrm{x}$ & $\mathrm{x}$ \\
\hline ruwbeemdgras & Poa trivialis & $\mathrm{x}$ & $\mathrm{x}$ & \\
\hline timothee & phleum pratense & & & $\mathrm{x}$ \\
\hline \multicolumn{5}{|l|}{ dicotylen } \\
\hline akkerdistel & Cirsium arvense & $\mathrm{x}$ & $\mathrm{x}$ & \\
\hline akkermelkdistel & Sonchus arvensis & $\mathrm{x}$ & & \\
\hline akkermunt & Mentha arvensis & $\mathrm{x}$ & & $x$ \\
\hline basterdwederik spec. & Epilobium & & $\mathrm{x}$ & $\mathrm{x}$ \\
\hline bijvoet & Artemisia vulgaris & & & $\mathrm{x}$ \\
\hline gewone paardebloem & Taraxacum officinale & & $\mathrm{x}$ & $x$ \\
\hline grote brandnetel & Urtica dioica & & & $x$ \\
\hline ridderzuring & Rumex. obtusifolius & & & $\mathrm{x}$ \\
\hline veenwortel & Persicaria amphibia & $\mathrm{x}$ & & \\
\hline \multicolumn{5}{|l|}{ overige } \\
\hline heermoes & Equisetum arvense & $\mathrm{x}$ & & \\
\hline \multicolumn{5}{|c|}{ Soorten die tijdens de monitoring zaad droegen } \\
\hline \multicolumn{5}{|c|}{ Soorten van vooral zandgrond in de Veenkoloniën } \\
\hline & & & & \\
\hline & & & & \\
\hline
\end{tabular}

\section{Onkruidontwikkeling in de stoppel}

$\mathrm{Na}$ de oogst van het graan blijf de stoppel de winter over liggen. Op een aantal bedrijven werd eind augustus of begin september een lichte stoppelbewerking toegepast, met een schijveneg of bouwvoorlichter. De vegetatie die aan het begin van de winter tussen de stoppels stond was een mix van gewasopslag, grassen (vooral straatgras, kweek en duist) en akkeronkruiden (maar dat aandeel was beperkt). De mate van begroeiing met genoemde soorten was heel wisselend. De variatie in stoppel was tussen jaren en bedrijven dan ook erg groot. De wijze van stoppelbewerking of juist geen stoppelbewerking bepaalde in sterke mate met hoeveel onkruid en gewasopslag een stoppel de winter in ging. Daarbij speelde grondsoort en graansoort ook een belangrijke rol. Bij zomergerst, op zandgrond in de Veenkoloniën, was de opslag van graan veel groter dan bij zomertarwe op de klei. Verder bepaalde de mate van veronkruiding in het groeiseizoen en het tijdstip van het toedienen van een herbicide, hoe sterk een stoppel uiteindelijk begroeid zal raken. Ter illustratie laten in Figuur 12 vier foto's (oktober 2017) duidelijk het verschil in stoppel zien bij verschillende stoppelbewerkingen. 


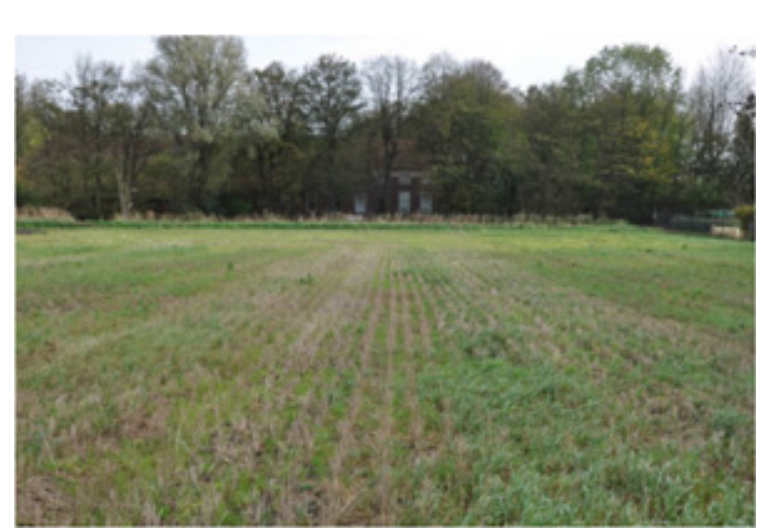

HEM Geen grondbewerking

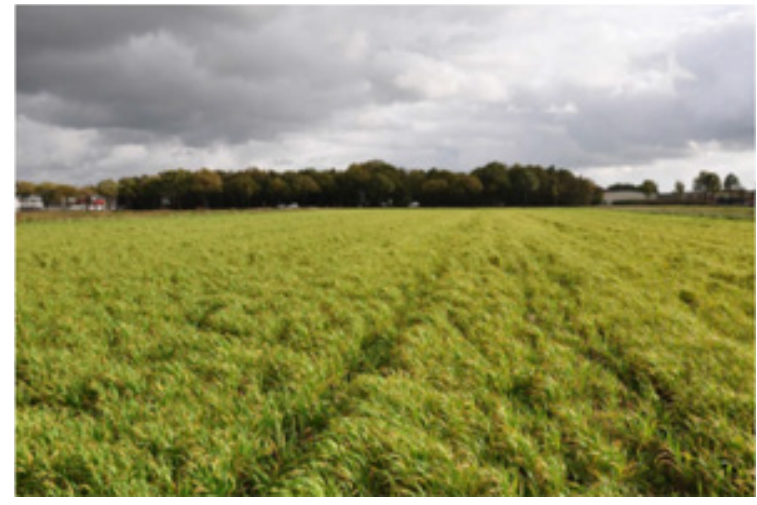

MF Schijveneg

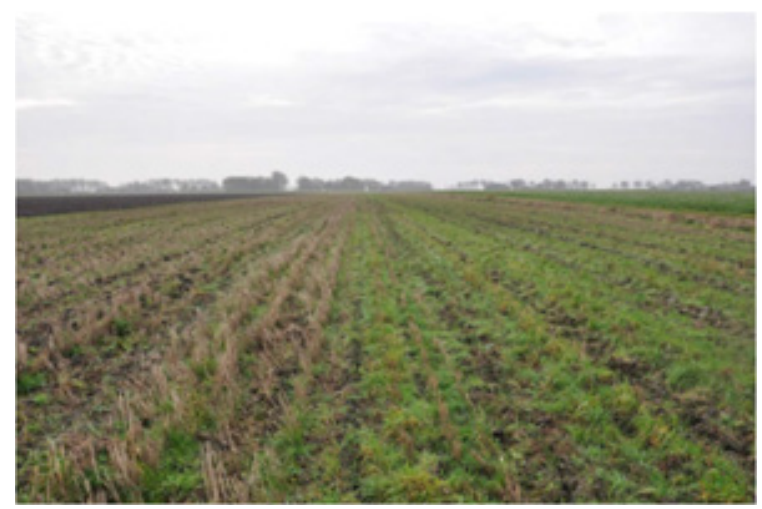

KdW Gewoeld

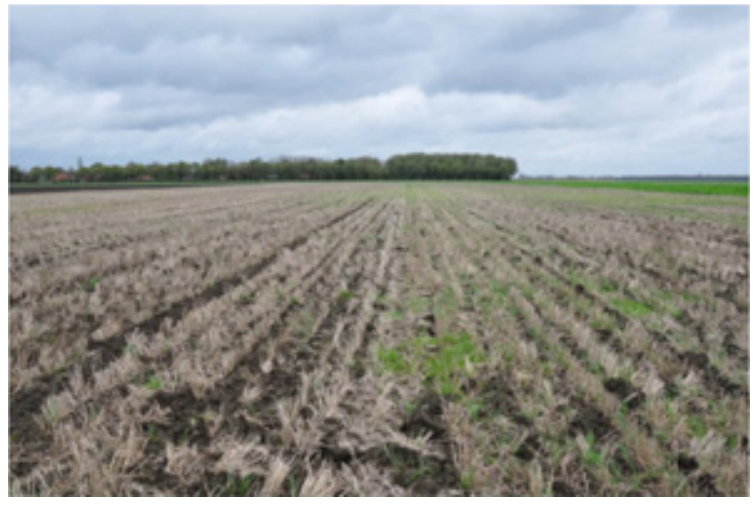

E Bouwvoorlichter

Figuur 12 Verschil in stoppels na verschillende grondbewerkingen.

\section{Samenvattend}

Helemaal geen herbicidegebruik bleek na twee jaar al onhoudbaar. De onkruidontwikkeling was zodanig dat van een acceptabele graanteelt geen sprake meer was en het draagvlak bij de deelnemers niet aanwezig meer was om deze variant in de proef het derde jaar nog voort te zetten.

De onkruiddruk in percelen met beperkt middelengebruik leverde een graanoogst op die voor de deelnemers wel acceptabel was. Daarbij was de onkruiddruk in de zomergraanpercelen met een beperkt gebruik van herbiciden op zandgrond aanzienlijk hoger is dan op de klei. De onkruidbedekking op de 6 bedrijven op de klei op het Hogeland en Oldambt bleef onder de $10 \%$ bedekking, waarbij die op de bedrijven op zand in de Veenkoloniën tussen de 20 en 50\% lag. Eerder is al aangegeven dat door het gebruik van herbiciden die selectief zijn voor dicotylen, grassen lijken toe te nemen. Op het moment dat het uit de hand dreigde te lopen, werd in het late najaar 2016 (MF) of het vroege voorjaar van 2017 de stoppel gespoten met glyfosaat (HK, HEM en RH). Op die wijze was de onkruiddruk in de hand te houden. Een geringe zaaizaadhoeveelheid en een grotere zaaiafstand tussen de rijen, draagt bij aan een opener gewas en hierdoor een grotere kans tot onkruidontwikkeling. Grondsoort, mate van stoppelbewerking, type gewas en onkruidontwikkeling in het groeiseizoen, bepalen hoe 'groen' een stoppel de winter in gaat. 


\subsubsection{Referentiepercelen wintertarwe, zomergranen, suikerbieten en aardappelen}

De referentiepercelen met hakvruchten, wintergranen of gangbare zomergranen waren in de proef opgenomen om een beeld te hebben wat de onkruiddruk in deze gewassen was. In deze gewassen werden gewasbeschermingsmiddelen ingezet die gangbaar worden geadviseerd voor deze teelten. De onkruiddruk op de referentiepercelen was op vrijwel alle bedrijven en in alle jaren erg laag. Zeker wintergraan kan als 'steriel' worden benoemd als het gaat om akkeronkruiden. De foto's in Figuur 13 illustreren dat.
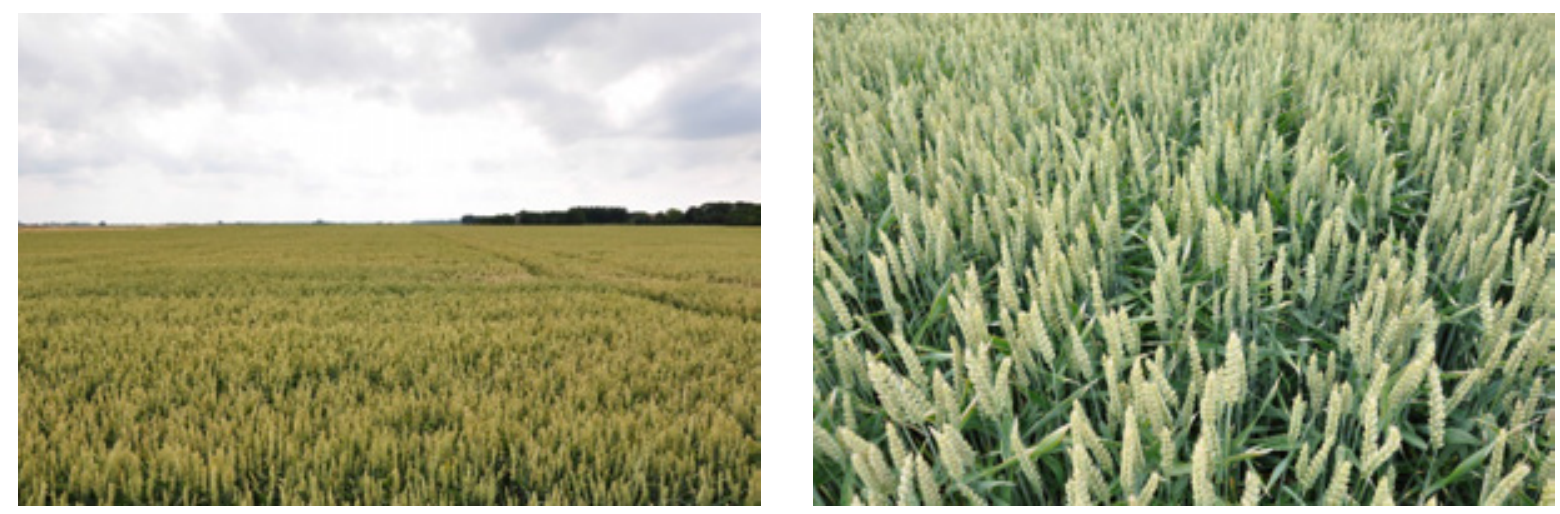

Wintertarwe
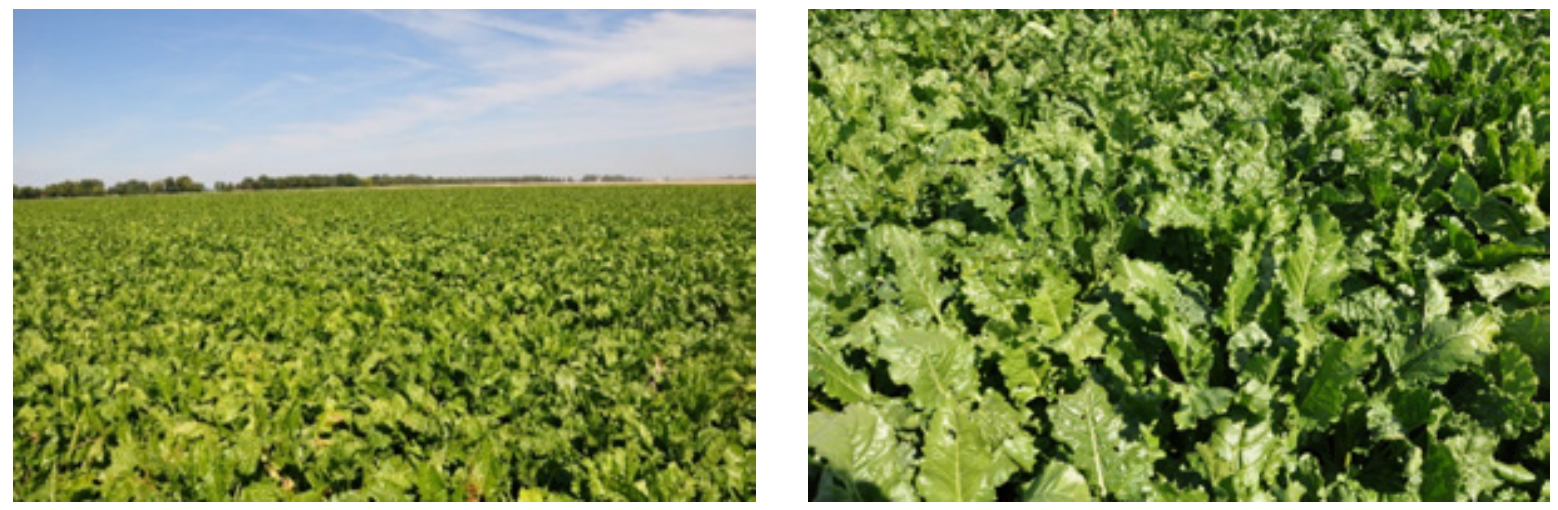

\section{Suikerbieten}
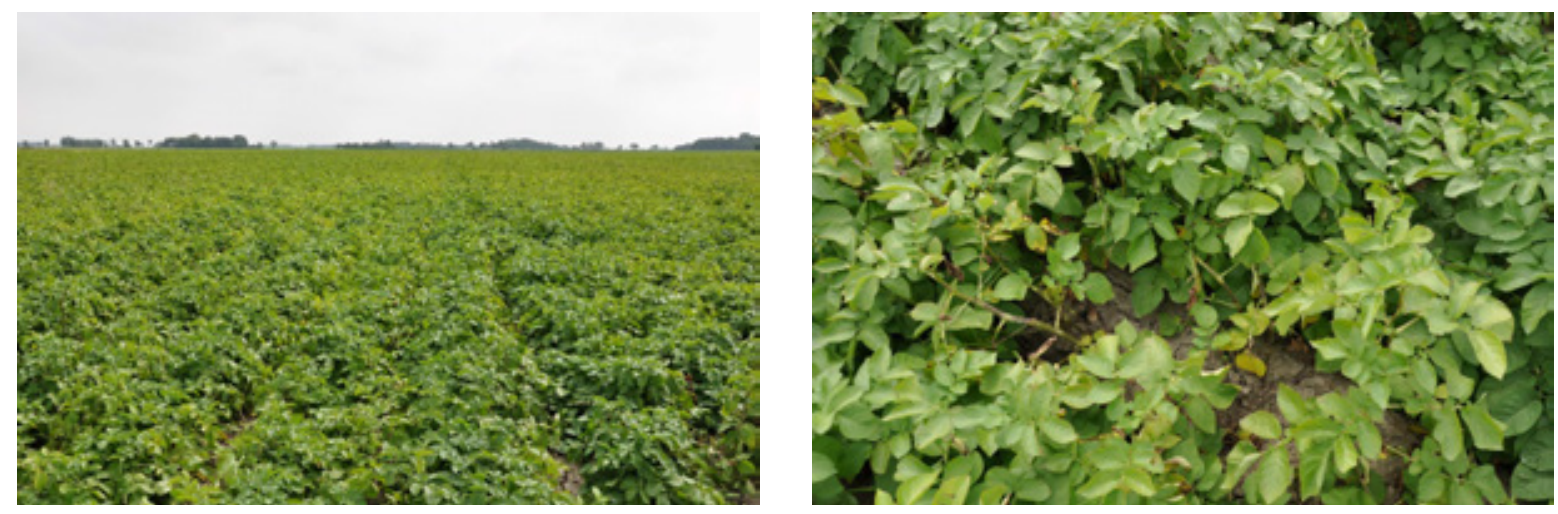

Aardappelen

Figuur 13 Referentiegewassen. 


\subsection{Akkervogels}

\subsubsection{Waarnemingen in broedseizoen}

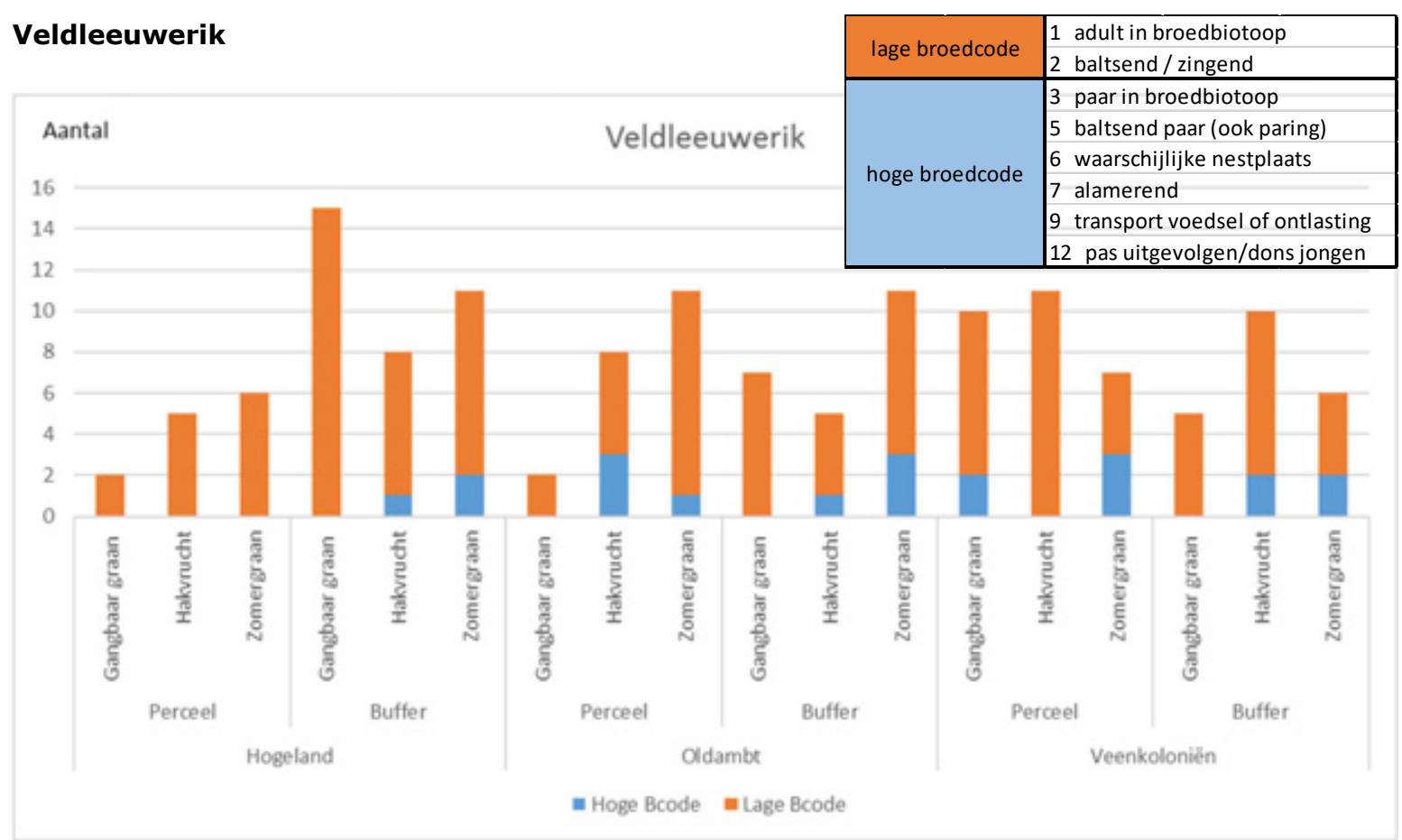

Figuur 14 De resultaten van de broedvogelmonitoring per regio voor de veldleeuwerik. Weergegeven zijn het totaal over 3 jaren (2015 t/m 2017).

De veldleeuwerik is een grondbroeder van kale of schaars begroeide bodems in een open landschap met weinig of geen opgaande landschapselementen. Naast het agrarische landschap broedt de soort in Nederland in heidevelden, kwelders en het open duinlandschap. Het eenvoudige nest bestaat uit een kommetje bekleed met wat vegetatie. In Nederland is de veldleeuwerik deels een standvogel en deels een korte afstandstrekker indien de omstandigheden daar om vragen (Hegemann et al., 2010).

De veldleeuwerik heeft in het vroege voorjaar een voorkeur voor zomergranen vanwege de groeiachterstand van het gewas ten opzichte van wintergranen. Naar verloop van het groeiseizoen worden echter ook de zomergranen verlaten ten faveure van de dan nog laag blijvende gewassen zoals hakvruchten (Chamberlain et al.,2001).

In de zomermaanden is de veldleeuwerik vrijwel geheel aangewezen op een dieet van ongewervelden die vanaf de grond worden gevangen. De jongen worden in de eerste week uitsluitend gevoed met insecten. Pas later in het seizoen, in de nazomer wordt overgeschakeld naar een meer plantaardig dieet en granen. In de winter zijn zadenrijke stoppelvelden en plantresten een belangrijke voedselbron (Cramp \& Simmons,2004).

Veldleeuweriken werden veelal in de directe nabijheid van de zomergraanpercelen aangetroffen. In vrijwel alle gevallen ging het om zingende mannetjes. In enkele gevallen waren er sterke aanwijzingen dat er gebroed werd in deze zomergraanpercelen. Uit de resultaten komt een lichte voorkeur voor zomergranen ten opzichte van wintergranen naar voren. In de Veenkoloniën hadden hakvruchten de voorkeur boven de zomergraanpercelen. Wel waren er hier wat meer aanwijzingen dat er in de zomergraanpercelen waarschijnlijk gebroed werd. 


\section{Gele kwikstaart}

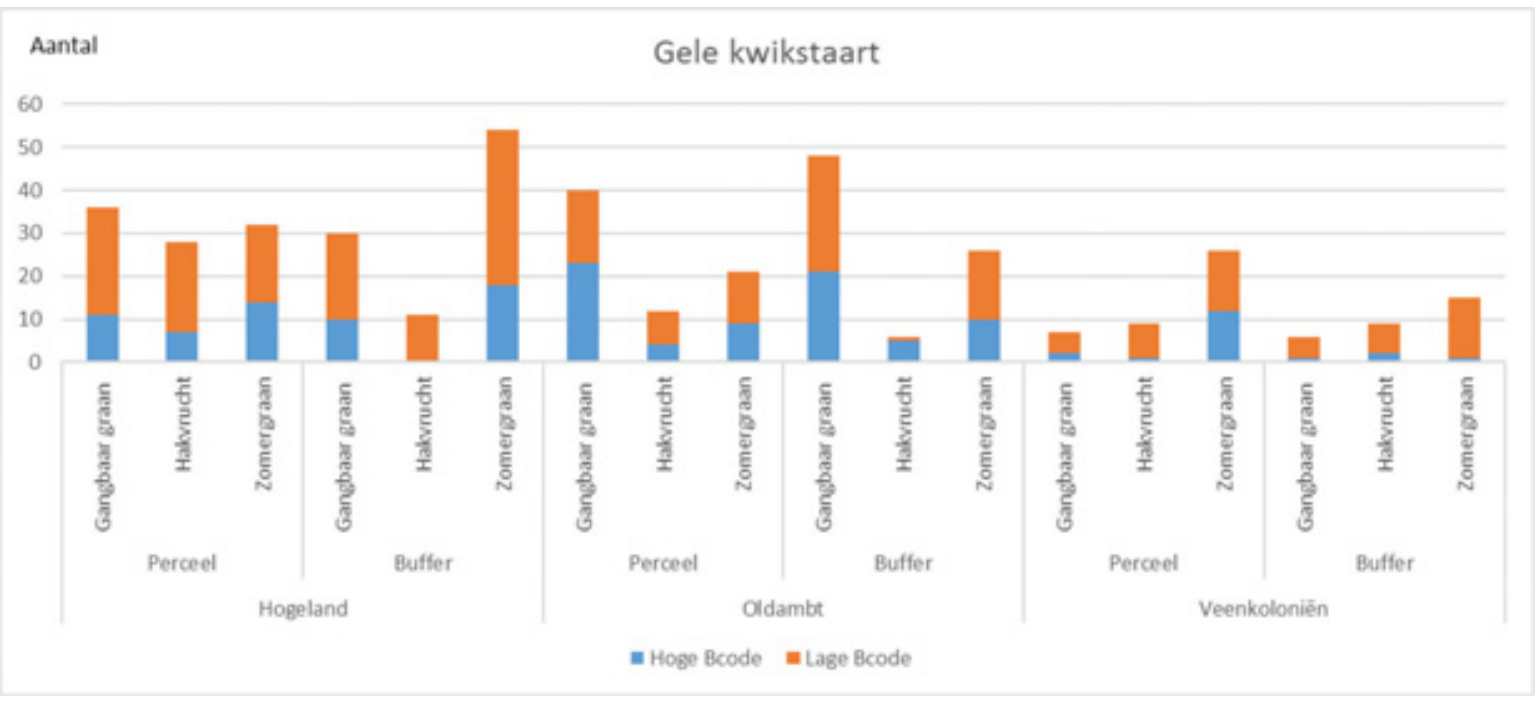

Figuur 15 De resultaten van de broedvogelmonitoring per regio voor de gele kwikstaart. Weergegeven zijn het totaal over 3 jaren (2015 t/m 2017).

De gele kwikstaart is een zomergast die overwintert in Afrika, voornamelijk in de Nigerdelta en het Tsjaadmeer (Zwarts et al.,2009). Gebroed wordt er op de grond, in een kuiltje bekleed met gras, haar, wol of vacht (Cramp \& Simmons, 2004). Vanaf begin tot midden april arriveren de eerste vogels. In Nederland broedt de soort in akkerbouwgewassen en in extensief grasland. Stedelijk gebied wordt vermeden maar de aanwezigheid van kleinschalige opgaande landschapselementen vormt geen grote belemmering.

Gefoerageerd wordt er op insecten door er naar te pikken, ze te achtervolgen of door deze in de lucht te vangen. De verschillende foerageertechnieken maakt dat de soort bij schaarste vermoedelijk makkelijker kan overstappen op andere soortgroepen insecten. De jongen hebben min of meer het zelfde dieet als de oudervogels, met als belangrijk verschil dat naarmate de jongen groeien, de ouders geleidelijk aan steeds grotere prooien aanbrengen (Cramp \& Simmons, 2004).

Alleen in de Veenkoloniën kwamen de zomergraanpercelen beter uit de resultaten dan de gangbare geteelde wintertarwe of hakvruchten. Op de zware kleigrond zijn de gangbaar geteelde wintergranen favoriet. In het Oldambt werd een hoog aantal waarnemingen gedaan. Op hakvruchten werden in het Oldambt en de Veenkoloniën weinig gele kwikstaarten waargenomen. Op het Hogeland waren de aantallen bij de drie teelten vergelijkbaar.

\section{Rietgors}

De rietgors komt voor in waterrijke moerasgebieden met uitgebreide rietzones en verspreid staande solitaire struiken of bomen die als zangpost gebruikt worden. De rietgors is niet strikt gebonden aan grootschalige moerassen of waterrijke gebieden met veel riet. Ook landbouwgebieden worden bezet. De aanwezigheid van ruigtekruiden met (niet noodzakelijkerwijs) riet in de nabijheid van water is al voldoende. In Nederland concentreert de verspreiding zich vooral rondom rivieren, meren of andere waterrijke gebieden.

De rietgors is door het jaar heen een voedselopportunist, in het voorjaar wordt vooral gefoerageerd op insecten en in de rest van het jaar wordt plantaardig materiaal en zaad genuttigd. De jongen worden uitsluitend met ongewervelden gevoerd. In het broedseizoen wordt langs oeverzones, in het riet of tussen de takken gefoerageerd. In de winterperiode is de rietgors meer grondgebonden en verblijft dan vaak op stoppelvelden, natuurbraak of overstaand graan (Koole, 2017).

Uit de resultaten vallen de Veenkoloniën op met duidelijk meer waarnemingen dan in de andere twee regio's. In het Oldambt is helemaal geen rietgors waargenomen. Op het Hogeland zijn een klein aantal rietgorzen waargenomen. 


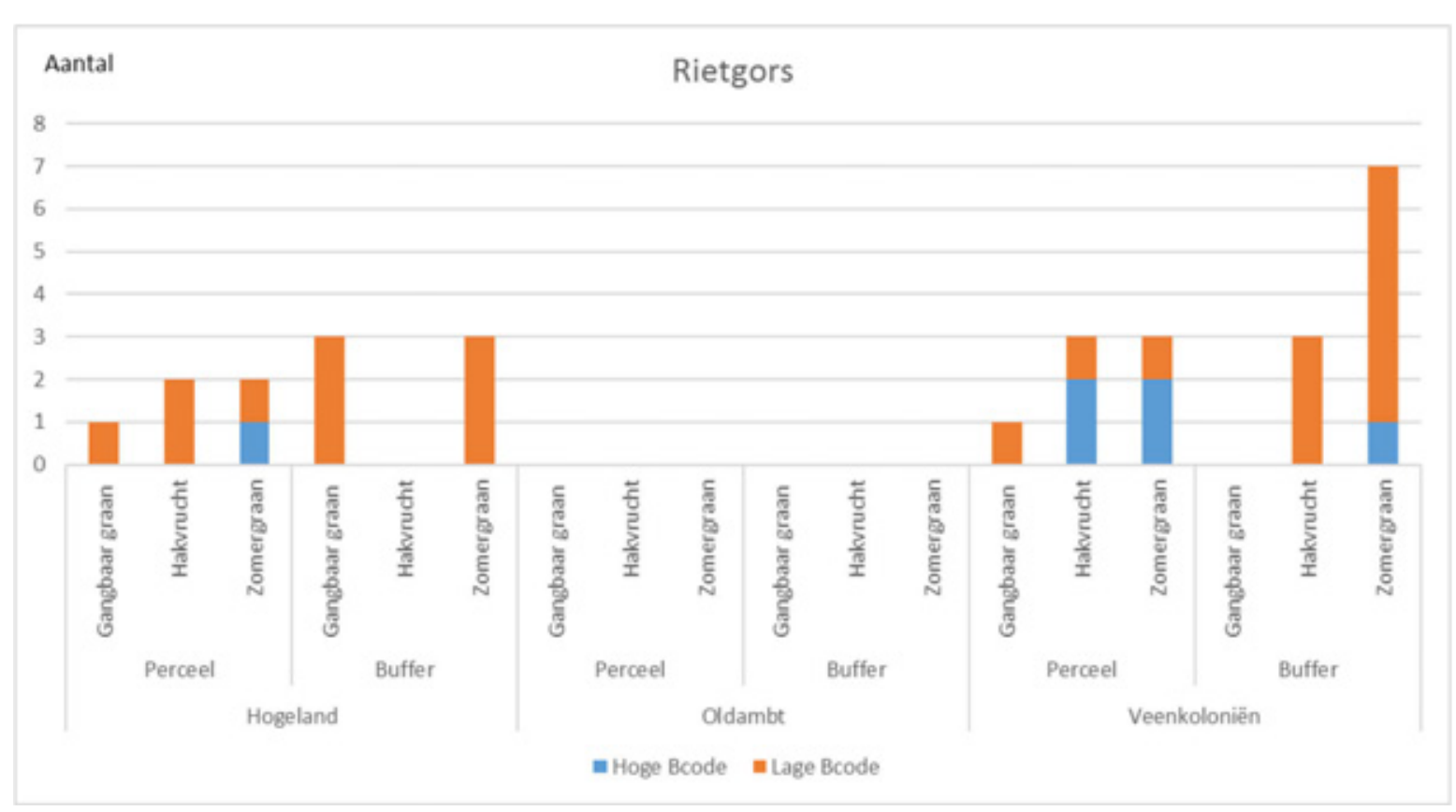

Figuur 16 De resultaten van de broedvogelmonitoring per regio voor de rietgors. Weergegeven zijn het totaal over 3 jaren (2015 t/m 2017).

\section{Graspieper}

De graspieper is in Nederland een standvogel die broedt in rijk geschakeerd en reliëfrijk grasland. De openheid van het landschap is een belangrijke voorwaarde. De soort is dan ook ruim vertegenwoordigd in akkerbouwgebieden, graslanden, kustzones en rivierdelta's. Het agrarisch cultuurlandschap met heggen en andere opgaande landschapselementen wordt grotendeels gemeden (Nederlandse Fauna 5, 2002). De moderne hoogproductieve graslanden bieden graspiepers geen geschikt leefgebied meer. In akkerbouwgebieden houden graspiepers zich op langs schouwpaden, bermen, taluds van watergangen of sloten.

Het dieet van volwassen vogels en jongen bestaat voornamelijk uit ongewervelden, 's winters wordt dat aangevuld met plantaardig materiaal waaronder zaden. De insecten worden al lopend vanaf de grond gevangen (Cramp \& Simmons, 2004).

Uit de resultaten vallen de aantallen in het Hogeland op. Met name in het gangbare wintergraan zijn de aantallen hier hoog in vergelijking met de andere gebieden en gewassoorten. Op het Hogeland is bijna 50\% meer waargenomen dan in het Oldambt. In de Veenkoloniën en in het Oldambt zijn slechts een paar waarnemingen gedaan waarbij het opvalt dat de hakvruchten en de zomergraanpercelen min of meer gelijke resultaten geven. 


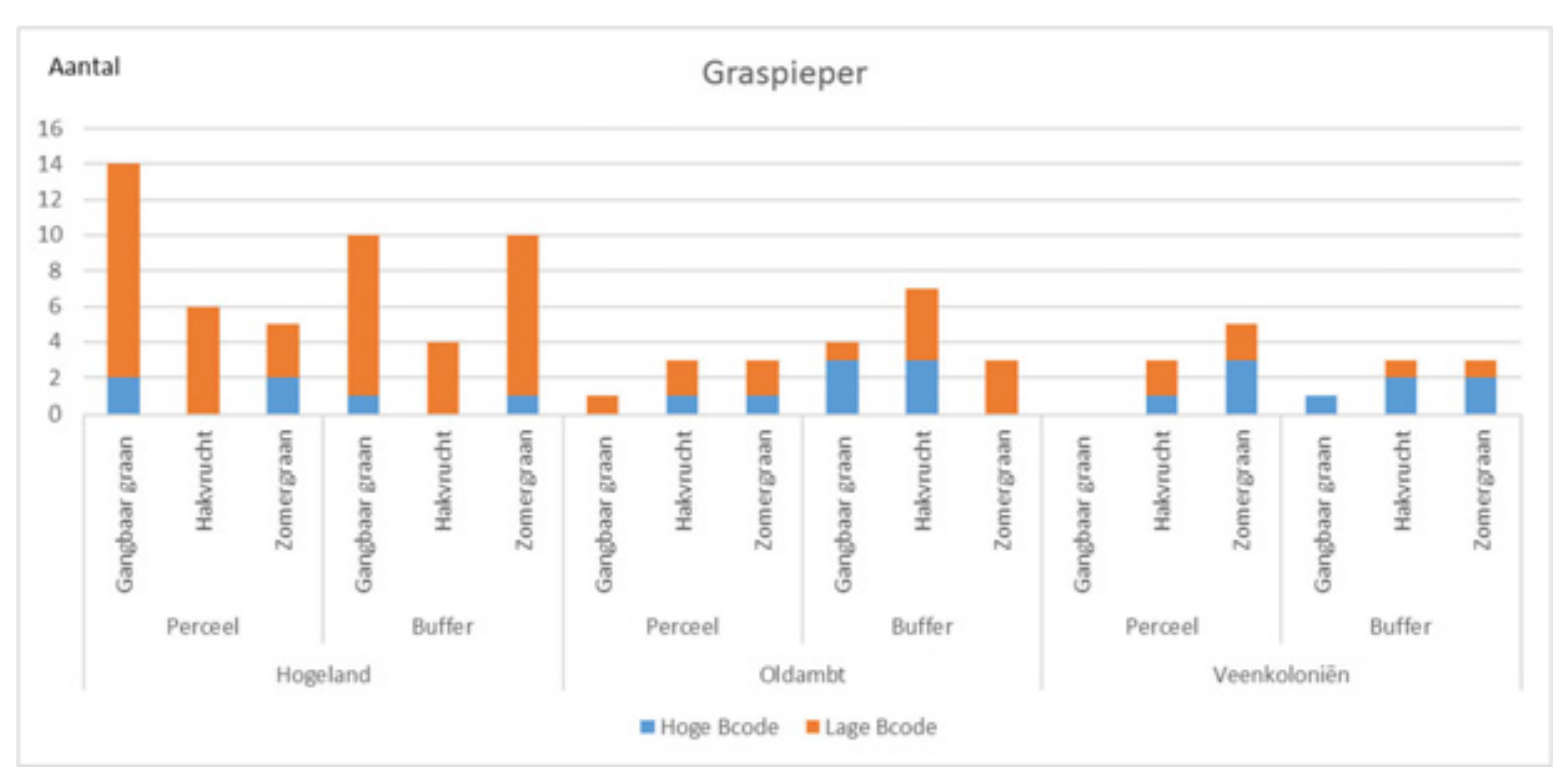

Figuur 17 De resultaten van de broedvogelmonitoring per regio voor de graspieper. Weergegeven zijn het totaal over 3 jaren (2015 t/m 2017).

\section{Kneu}

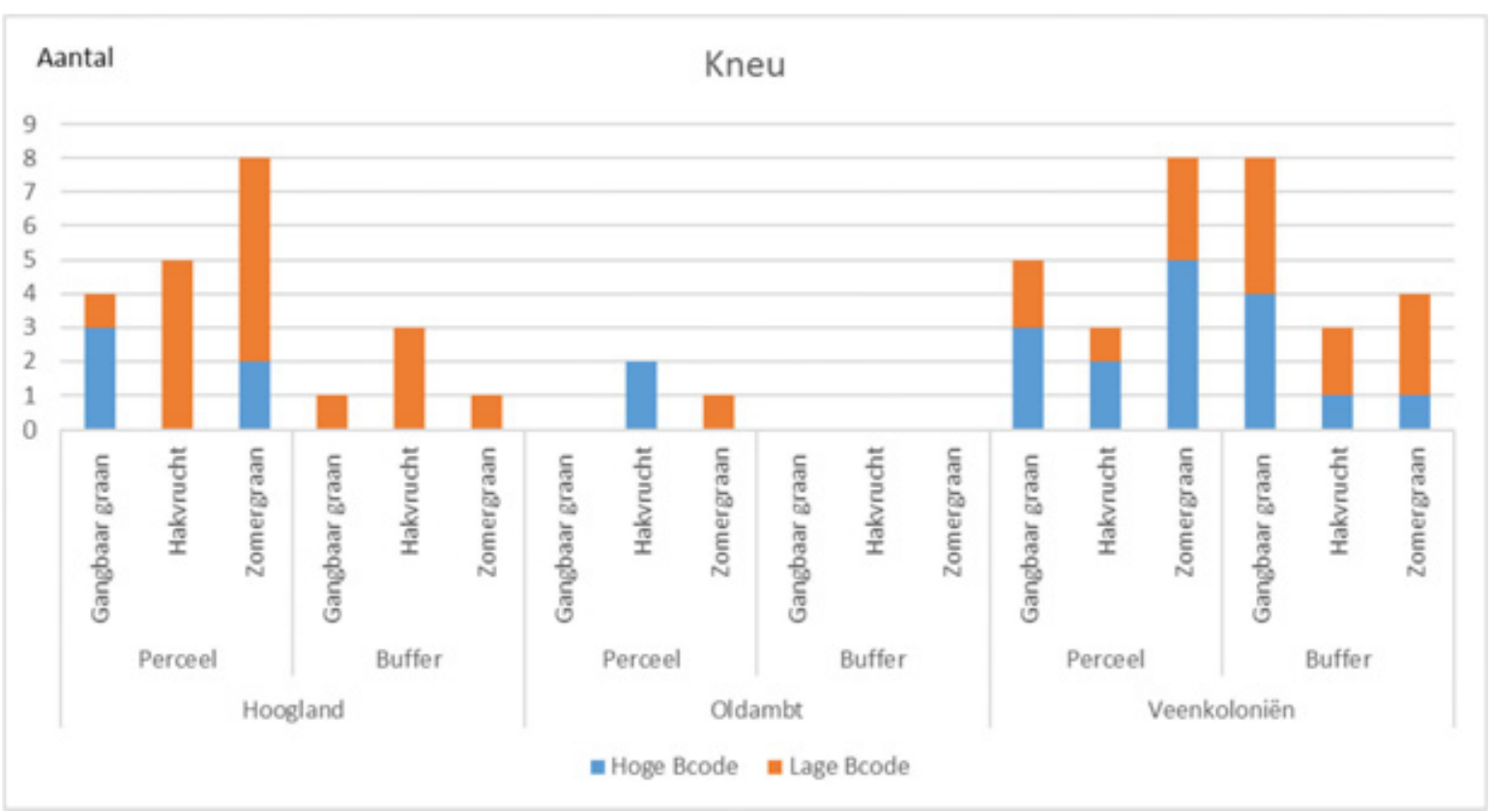

Figuur 18 De resultaten van de broedvogelmonitoring per regio voor de kneu. Weergegeven zijn het totaal over 3 jaren (2015 t/m 2017).

De kneu is in Nederland een overzomeraar die overwintert in het Middellandse Zeegebied. Enkele vogels blijven echter overwinteren als de voedselsituatie dat toelaat (Cramp \& Simmons, 2004). De kneu is sterk gebonden aan bloemrijke vegetaties met wat laag struweel dat als zangpost wordt gebruikt. Kwelders, rivierdelta's, kustzones, braakliggende akkers of ruderaal terrein hebben een zekere voorkeur. Een al te open landschap, aaneengesloten bossen en stedelijk gebied wordt gemeden. De kneu is al snel tevreden met een marginaal klein stukje geschikt habitat (Nederlandse Fauna 5, 2002). Het is een typische bewoner van het kleinschalige cultuurlandschap dat nog maar op weinig plaatsen te vinden is.

De kneu is een echte zaadspecialist en foerageert niet of nauwelijks op insecten. Ook de jongen worden gevoerd met zaden, mogelijk aangevuld met wat insecten. Zaden van de duizendknoop-, kruisbloem- en de composietenfamilie (Cramp \& Simmons, 2004) hebben de voorkeur. De kleine 
zaden van hennep, indien aanwezig, maken een substantieel deel uit van het dieet, zie ook de wetenschappelijke naam van de kneu (Carduelis Cannabina).

Op het Hogeland en in de Veenkoloniën is de kneu duidelijk beter vertegenwoordigd dan in het Oldambt. De zomergraanpercelen zijn favoriet waarbij opvalt dat er in de Veenkoloniën sterke aanwijzingen waren dat er in de directe omgeving van de zomergraanpercelen gebroed werd, dat was op het Hogeland wat minder. Opvallend genoeg werden in de gangbare teelten hoge broedcodes waargenomen.

\section{Geelgors}

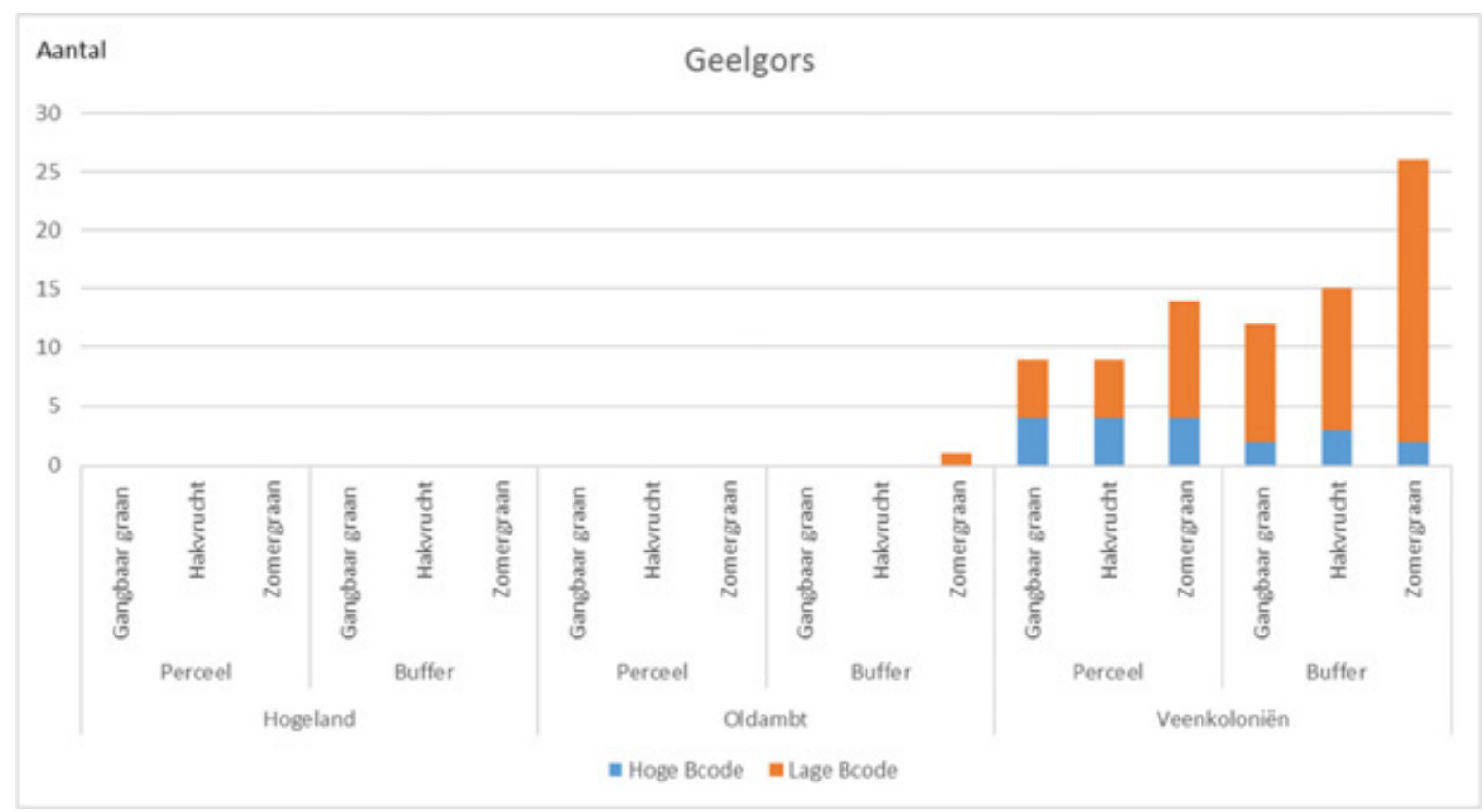

Figuur 19 De resultaten van de broedvogelmonitoring per regio voor de geelgors. Weergegeven zijn het totaal over 3 jaren (2015 t/m 2017).

De geelgors is een soort van het kleinschalige akkerbouwlandschap met een gevarieerd bouwplan en met hagen, heggen, solitaire struiken of boomgroepen. In Europa is de soort een standvogel. Mogelijk worden in de winterperiode de lokale populaties met vogels elders uit Europa aangevuld (Koole 2015). De soort is echter niet strikt gebonden aan het agrarisch gebied. Ook bosranden, bosaanplant, kapvlaktes, heidevelden en stuifzanden behoren tot het leefgebied. De soort komt in Nederland alleen nog exclusief voor in de oostelijke helft van het land (Nederlandse Fauna 5, 2002).

De geelgors foerageert op zaden hoofdzakelijk uit de grassenfamilie die van de bodem worden gepikt. In het broedseizoen bestaat het dieet uit ongewervelden die ook aan de jongen worden gevoerd (Cramp \& Simmons,2004).

Uit de resultaten komt de oostelijke verspreiding heel goed naar voren. Het Hogeland bleef onbezet en in het Oldambt is één territorium vastgesteld. In de Veenkoloniën waren de zomergraanpercelen duidelijk favoriet. In de meeste gevallen zijn zingende mannetjes waargenomen. Er waren in enkele gevallen sterke aanwijzingen dat er gebroed werd in of direct naast de percelen. De hakvruchten kwamen iets beter uit de resultaten naar voren dan het gangbaar geteelde graan.

\section{Ringmus}

De ringmus is in Groningen vrijwel strikt gebonden aan het half open agrarisch cultuurlandschap. Gebroed wordt er in verspreid liggende bebouwing tussen spleten, kieren, onder dakpannen of in nestkasten. De soort kan echter ook worden aangetroffen in kleine bosaanplanten waar gebroed wordt in natuurlijke holtes of als medebewoner van nesten van havik, buizerd of roek. Het zwaartepunt van de populatie ligt in Overijssel, Gelderland en Brabant (Nederlandse Fauna 5, 2002). 


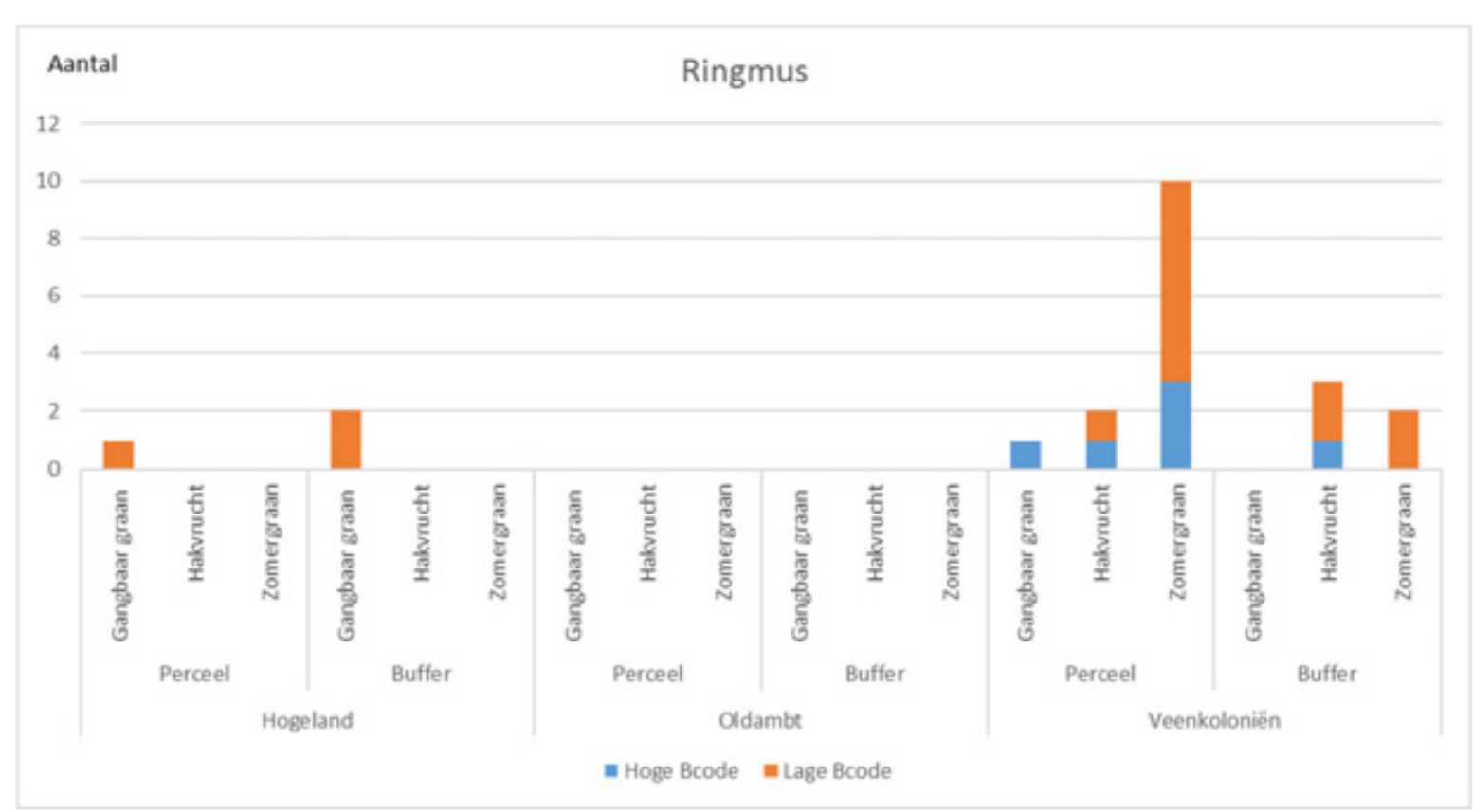

Figuur 20 De resultaten van de broedvogelmonitoring per regio voor de ringmus. Weergegeven zijn het totaal over 3 jaren (2015 t/m 2017).

Het voedsel bestaat voornamelijk uit zaden en ongewervelden afhankelijk van de beschikbaarheid (Cramp \& Simmons, 2004). De jongen worden gevoed met insecten. Het is een standvogel die 's winters vaak samen met de nauw verwante huismus en soms met groepen vink- of kraaiachtigen op stoppelvelden foerageert.

Uit de resultaten komen de Veenkoloniën duidelijk als voorkeursgebied naar voren. De soort ontbrak op de zware klei van het Oldambt en op het Hogeland zijn slecht drie waarnemingen gedaan. Opvallend is dat de zomergraanpercelen sterk de voorkeur kregen boven de andere twee onderzochte gewassen.

\section{Kwartel}

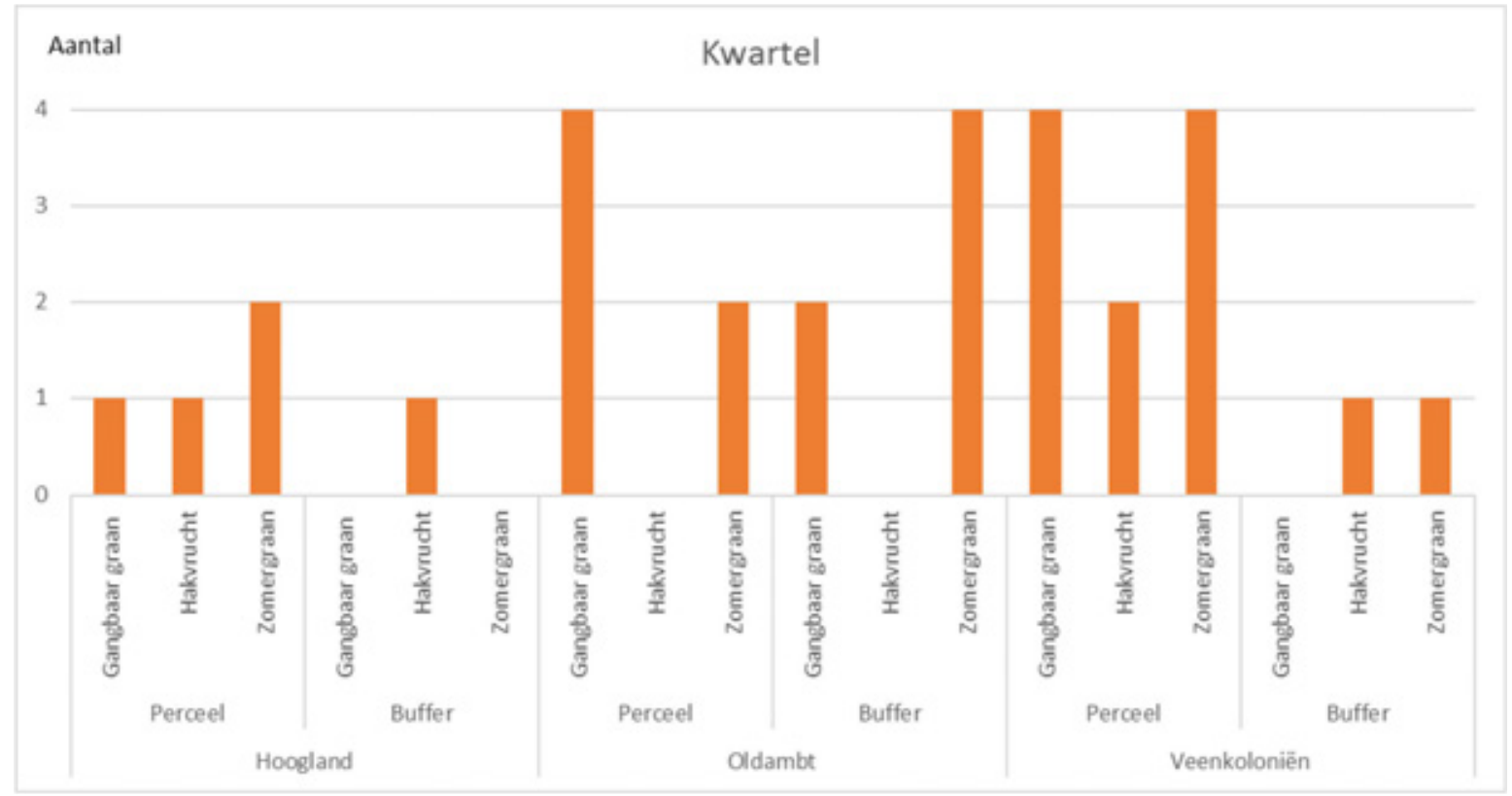

Figuur 21 De resultaten van de broedvogelmonitoring per regio voor de kwartel. Weergegeven zijn het totaal over 3 jaren (2015 t/m 2017). 
De kwartel is een overzomeraar die overwintert in het Middellandse zeegebied tot aan de evenaar in Afrika. In Nederland ligt de kern van de verspreiding in de grootschalige open akkerbouwgebieden. De hoogste dichtheden worden gehaald in Flevoland en in het veenkoloniaal bouwplan van OostGroningen en Drenthe (Nederlandse Fauna 5, 2002) waar zomergranen de voorkeur krijgen. Naast akkerbouwpercelen worden kwartels in goede jaren ook in extensief grasland waargenomen. Hiernaast zijn kwartels te vinden nabij zandige of stoffige plekken, bijvoorbeeld zand- of kleipaden. Hier kunnen de vogels stof- of zandbaden nemen.

De kwartel is een omnivoor met een dieet dat grotendeels bestaat uit ongewervelden en zaden.

Gefoerageerd wordt er op de bodem door met de snavel of met de poten in de grond te krabben. Dit wordt vooral in de namiddag en avond gedaan (Cramp \& Simmons, 2004).

De kwartel kent de hoogste dichtheden in de Veenkoloniën. Het voorkomen is echter niet strikt gebonden aan de graanteelten, ook werden enkele waarnemingen gedaan in de hakvruchten. Alleen op het Hogeland kwamen de zomergraanpercelen beter uit de resultaten.

\section{Fazant}

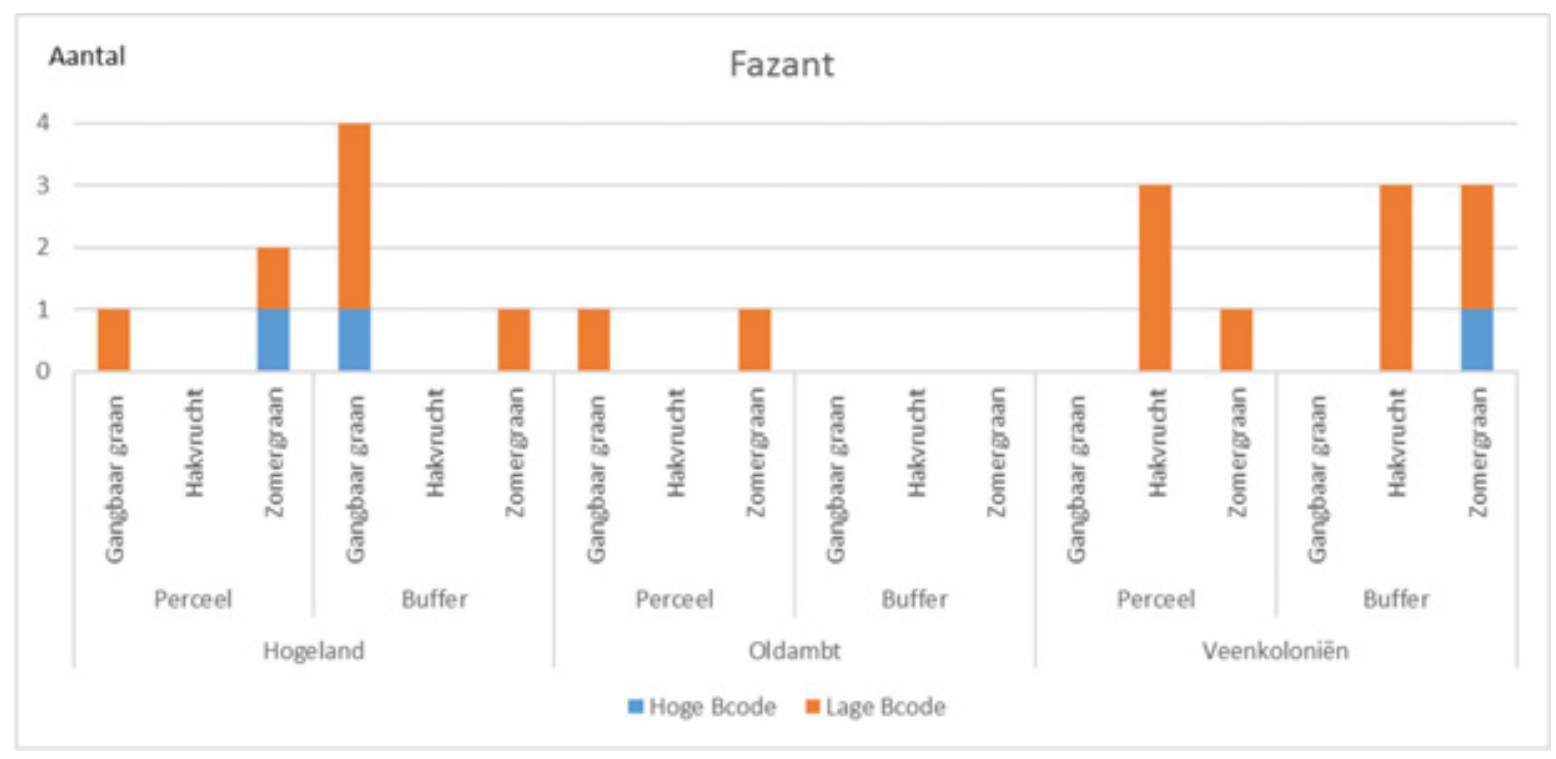

Figuur 22 De resultaten van de broedvogelmonitoring per regio voor de fazant. Weergegeven zijn het totaal over 3 jaren (2015 t/m 2017).

De fazant is van oorsprong een exoot die vanuit Azië al rond het begin van de jaartelling als sier- en jachtvogel is geïntroduceerd. Deze standvogel haalt in Nederland de hoogste dichtheden in de akkerbouwgebieden van Oost-Groningen en Zeeland. De combinatie van ruigtes met veel grassen en kruiden en de grootschalige teelt van granen zijn hier leidend in. Mogelijk spelen ook predatie en jacht een rol in het lokale voorkomen van de fazant. De fazant is niet strikt gebonden aan het agrarisch gebied; verboste moerassen, natuurgebieden, duinen of rivierdelta's vormen ook een aantrekkelijk biotoop (Nederlandse Fauna 5, 2002).

De fazant heeft een breed voedselspectrum; zaden, fruit, bessen granen, blad, wortelstokken en zelfs kleine gewervelden maken deel uit van het menu. In het voorjaar worden de jongen gevoed met insecten. Gefoerageerd wordt er door te schrapen en te pikken op en in de bodem. Een fazant kan met de poten zand verplaatsten en kan tot $8 \mathrm{~cm}$ diep naar wortels graven (Cramp \& Simmons, 2004).

Alleen in de Veenkoloniën en op het Hogeland zijn een paar waarnemingen gedaan, in het Oldambt is slechts twee keer een fazant waargenomen. Het zomergraan had wel de voorkeur van de drie onderzochte teelten. 


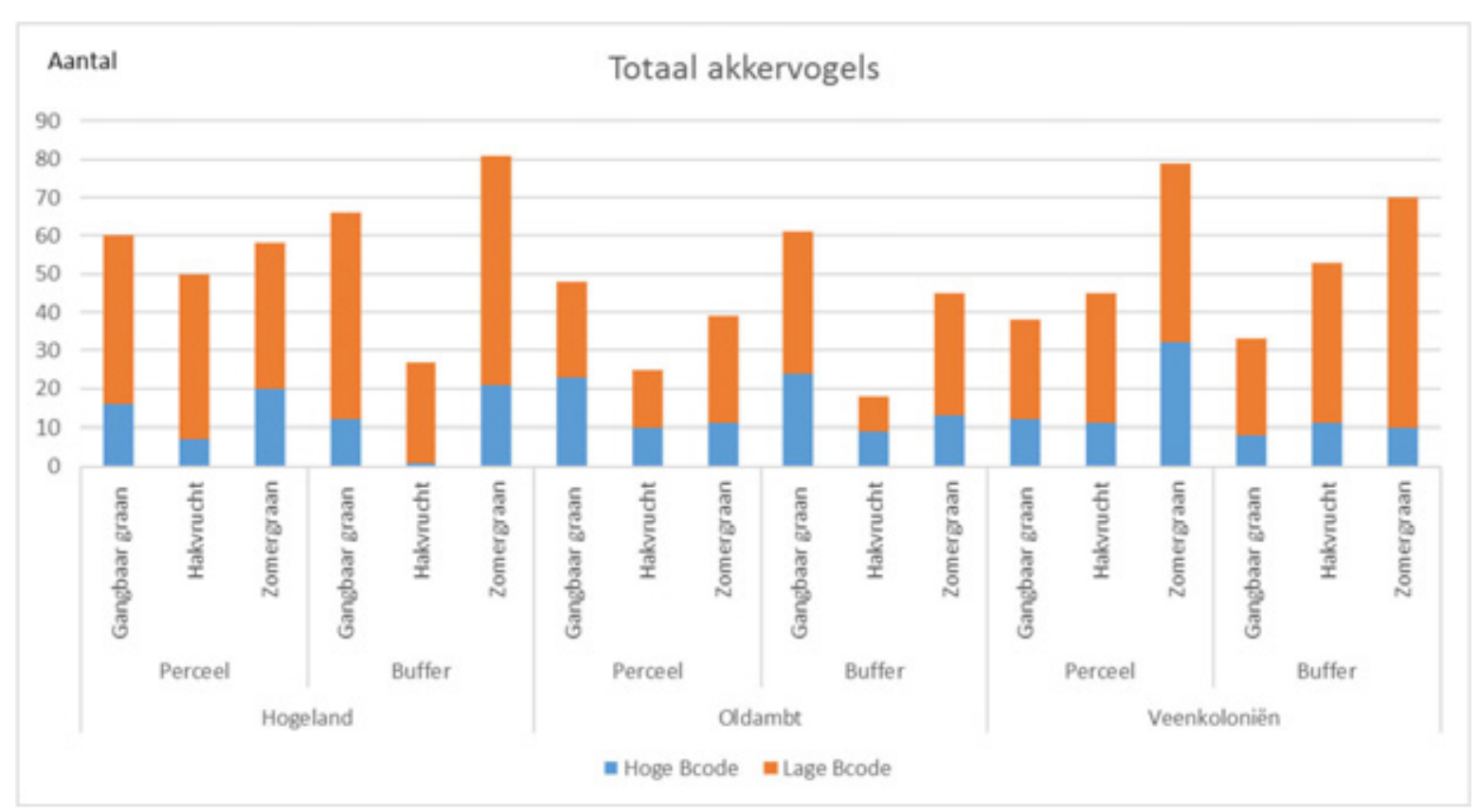

Figuur 23 De resultaten van de broedvogelmonitoring per regio voor alle 9 akkervogelsoorten. Weergegeven is het totaal over 3 jaren (2015 t/m 2017).

\section{Samenvattend}

Uit de resultaten kwamen geen eenduidige resultaten naar voren die wezen op een positief resultaat voor de teelt van extensieve zomertarwe. Wel waren er sterke aanwijzingen dat de teelt van extensieve zomertarwe op de zware kleigronden een versterking van het leefgebied voor de veldleeuwerik biedt. Hiernaast viel op dat typische zaadspecialisten als kneu en ringmus duidelijk een grotere voorkeur hadden voor de zomergraanpercelen met beperkte inzet van gewasbescherming dan voor de gangbare teelten. Zeer waarschijnlijk is de kruidenrijkheid van de zomergraanpercelen voor deze soorten van doorslaggevende betekenis geweest.

Ook kwamen duidelijke regioverschillen naar voren, het meest in het oog sprong de geelgors die vrijwel exclusief in de Veenkoloniën is waargenomen. Dit gold ook, in mindere mate, voor de kneu en de ringmus die wat meer gebonden zijn aan het veen of zand met kleinschalige landschapselementen en de openheid van de kleigronden grotendeels mijden.

Naast deze 9 typische akkervogels zijn er tal van andere vogels waargenomen, in totaal zijn er 100 soorten waargenomen, zie Bijlage 4. 


\subsubsection{Waarnemingen in winter}

Tabel 9 Soorten die in de winterperiode foerageren op de akkers ingedeeld naar voedsel voorkeur.

\begin{tabular}{|l|l|l|}
\hline \multicolumn{2}{|c|}{ Zaadeters } & Muizenspecialisten \\
\hline \multicolumn{1}{|c|}{ grondgebonden } & niet-grondgebonden & \\
\hline bokje & barmsijs & buizerd \\
\hline fazant & frater & blauwe reiger \\
\hline geelgors & goudvink & grote zilverreiger \\
graspieper & keep & ruigpootbuizerd \\
grote lijster & kneu & torenvalk \\
holenduif & putter & rode wouw \\
\hline houtduif & rietgors & blauwe kiekendief \\
ijsgors & ringmus & \\
\hline kauw & vink & \\
\hline kievit & & \\
koperwiek & & \\
kramsvogel & & \\
veldleeuwerik & & \\
waterpieper & & \\
watersnip & & \\
zwarte kraai & & \\
\hline
\end{tabular}

In Tabel 9 zijn de waargenomen akkervogelsoorten ingedeeld naar voedselvoorkeur. In deze tabel is bij de zaadeters onderscheid gemaakt tussen soorten die hun voedsel op de grond verzamelen en soorten die niet-grondgebonden zijn, d.w.z. het zaad direct van de plant pikken. Dit onderscheid is niet per definitie altijd soort gebonden. De niet-grondgebonden soorten kunnen bij afwezigheid van planten ook foerageren op de bodem.

In Figuur 24 is bij de zaadeters geen onderscheidt meer gemaakt tussen de meer grondgebonden en niet-grondgebonden soorten. Niet alle soorten (zie Bijlage 5) die zijn aangetroffen zijn in de tabel opgenomen. Zo zijn watervogels, ganzen, eenden, steltlopers, bos- en tuinvogels en een aantal generalisten niet in deze tabel opgenomen, omdat deze soorten niet echt aan bouwland gebonden zijn. Waar (akker)vogels foerageren en verblijven in de winterperiode is sterk afhankelijk van de begroeiing die op dat moment op de akkers aanwezig is. Voor de onderzoekspercelen met zomergranen was dat een stoppel die in veel gevallen licht bewerkt was en in verschillende mate was begroeid (zie 3.2 Ontwikkeling onkruiddruk). Voor de controlepercelen met wintergraan, gangbaar zomergraan en hakvruchten varieerde de begroeiing sterk. Dat varieerde van kale grond, nieuw ingezaaide wintertarwe, groenbemesters of een geoogst bieten- of aardappelperceel met gewasresten. Naast foerageren worden de percelen ook gebruikt voor dekking en rusten.

De zaadetende soorten in Figuur 24 hebben een voorkeur voor de zomergraanstoppels (vooral veldleeuwerik), maar hakvruchten scoren op sommige momenten in de winter ook goed.

Bij de tellingen moet een kanttekening worden gemaakt. In het eerste jaar lagen op de bedrijven de controlepercelen en onderzoekspercelen met zomergraan te dicht bij elkaar, waardoor ze elkaar beïnvloeden. Dit is dan ook de reden dat in de winter van 2015/2016 op slechts vier percelen met wintergraan en vier percelen met hakvruchten de wintervogels konden worden geteld. Dit kan een enigszins vertekent beeld voor het eerste jaar geven. In de volgende twee jaren grensden de controlepercelen niet meer aan de zomergraanpercelen en zijn de wintervogels op alle percelen geteld. Naast zaden eten veel van deze vogels, vooral de bodem gebonden akkervogels, ook groene plantendelen. Door de (bloeiende) grassen en onkruiden, achtergebleven graankorrels, gewasopslag en stoppels hebben de zomergraanstoppels een grote aantrekkingskracht op akkervogels.

Als we naar een aantal specifieke soorten kijken (Figuren 26-28) dan valt op dat een soort als de veldleeuwerik vooral op de zomergraanstoppels aangetroffen werd op de klei in Hogeland en Oldambt en in geringere mate op de zomergraanstoppel op het zand in de Veenkoloniën. In Oldambt heeft drie jaar een stoppel gelegen (BtH) waarbij in het voorjaar een niet-kerende grondbewerking plaatsvond en na de oogst de stoppel geen enkele grondbewerking heeft ondergaan. Op deze stoppel werden de 
hoogste dichtheden veldleeuwerik aangetroffen. Deze hoge aantallen werden echter vrijwel altijd tijdens de eerste of laatste telrondes vastgesteld. Mogelijk spelen migratiestrategieën van de veldleeuwerik hierin een belangrijke rol (Hegemann et al., 2010). Dat verklaart waarschijnlijk ook waarom in enkele telrondes hoge piekaantallen werden waargenomen terwijl er in de overige telrondes geen veldleeuwerik werd waargenomen.

In enkele gevallen kiemde zomertarwekorrels onder de warme weersomstandigheden en bedekte de stoppel volledig. Dit bood de graspieper een goed en duurzaam overwinteringsbiotoop. Dit in tegenstelling tot andere percelen weliswaar incidenteel hoge aantallen zijn waargenomen maar waar de aanwezigheid zich beperkte tot een, twee of drie rondes. Een soort als de geelgors heeft duidelijk een voorkeur voor graanstoppels op zandgrond in de Veenkoloniën.

Roofvogels en reigers (Figuur 25) lijken geen echte voorkeur voor de zomergraanstoppels te hebben. Zowel de percelen met hakvruchten en wintergranen alsook de zomergraanstoppels werden gedurende de hele winter ongeveer gelijkmatig bezocht. Roofvogels en reigers werden ook in de directe nabijheid van de percelen geteld waardoor de precieze voorkeuren niet goed konden worden herleid. Hiervoor waren de onderzochte percelen vermoedelijk ook te klein. 


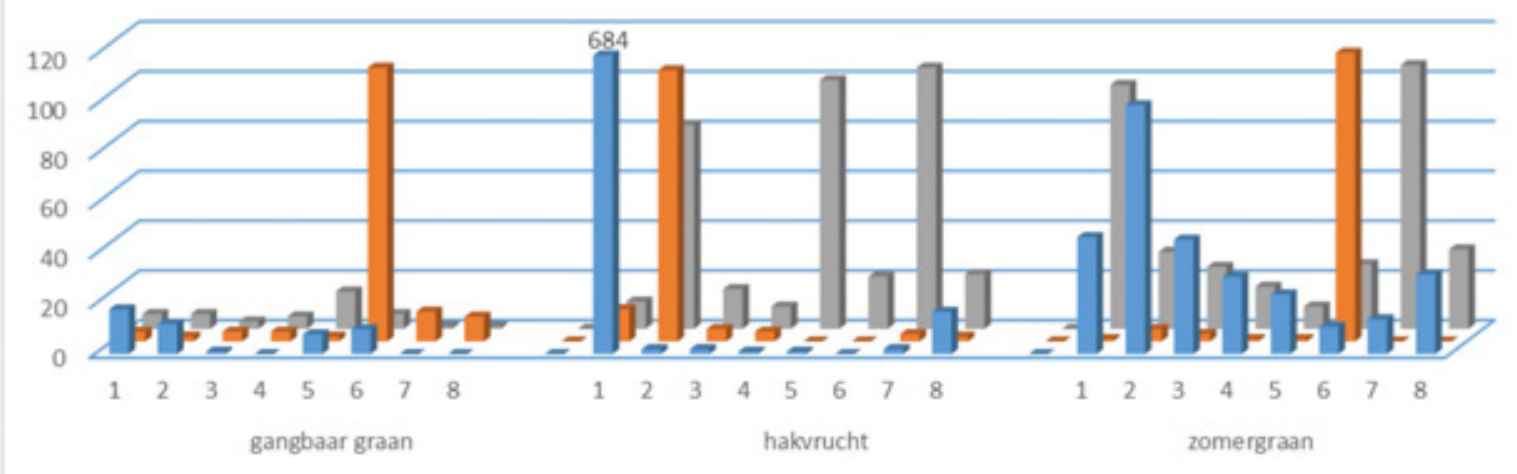

\section{Zaadeters Oldambt}

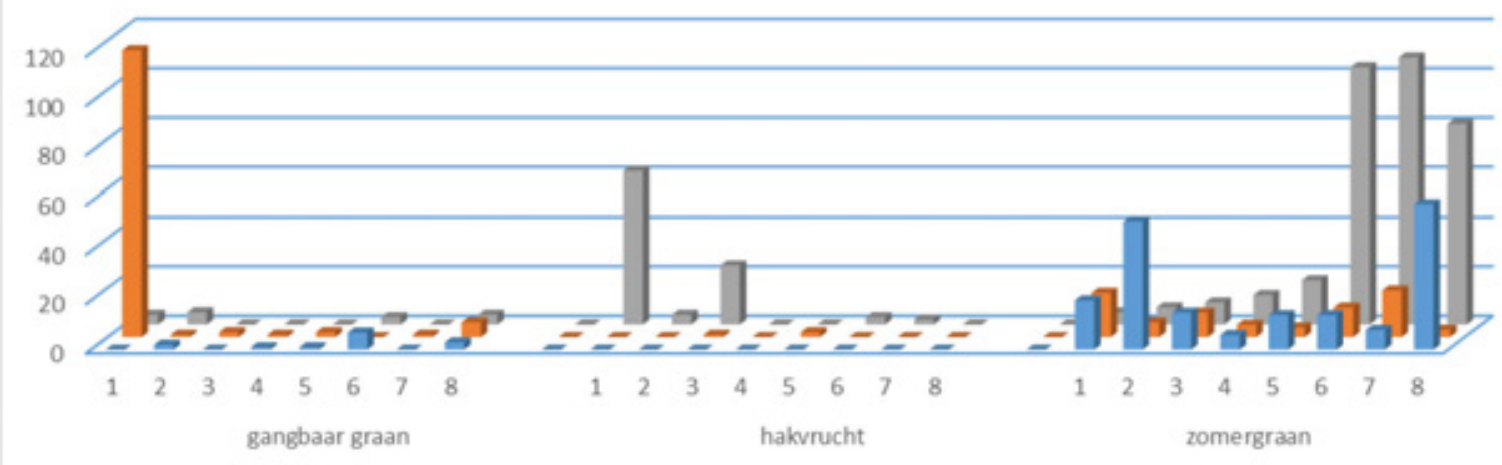

\section{Zaadeters Veenkoloniën}

jaar =15/16 =16/17 =17/18

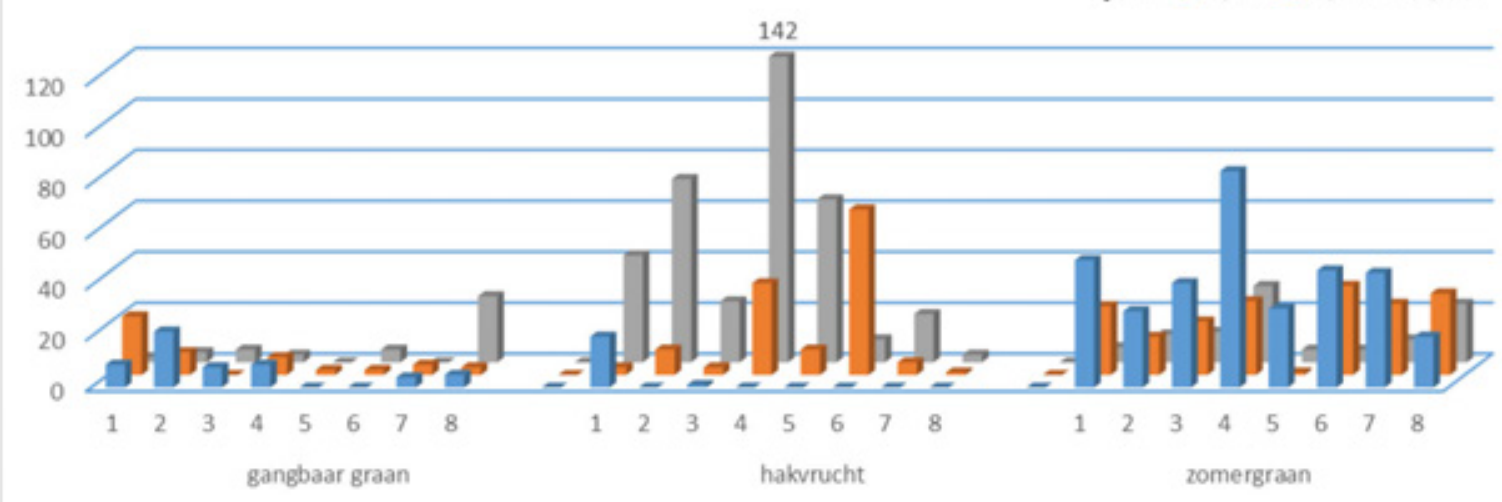

Figuur 24 Het totaal aantal zaadetende vogels die waargenomen zijn per regio en per telronde ( $1 \mathrm{t} / \mathrm{m}$ 8) op de percelen gedurende de 3 winterperiodes. 

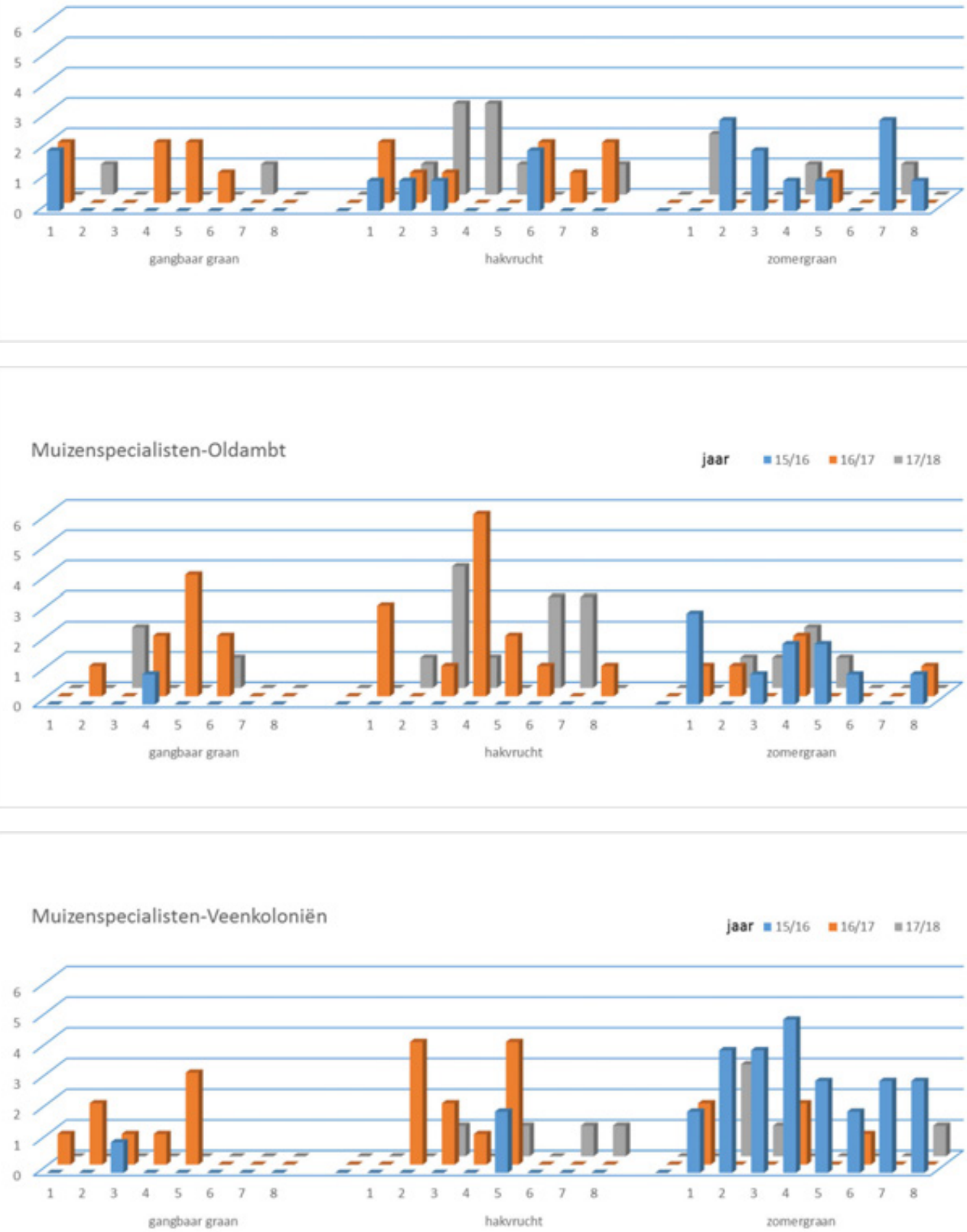

Figuur 25 Het total aantal muizenetende vogels die waargenomen zijn per regio en per telronde (1 t/m 8) op de percelen gedurende de 3 winterperiodes. 


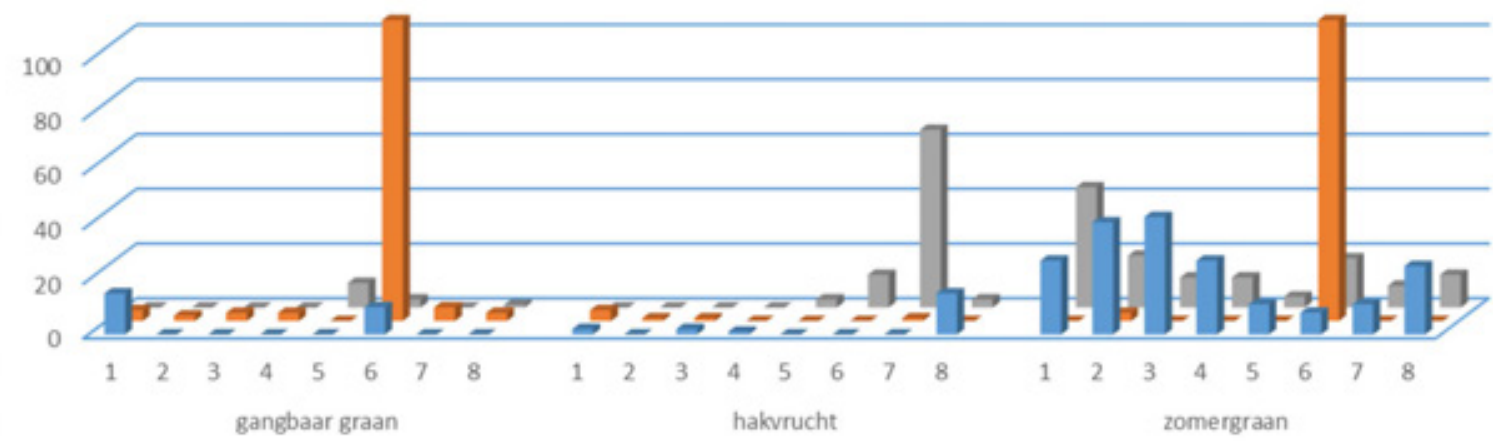

Veldleeuwerik-Oldambt

jaar $=15 / 16=16 / 17=17 / 18$

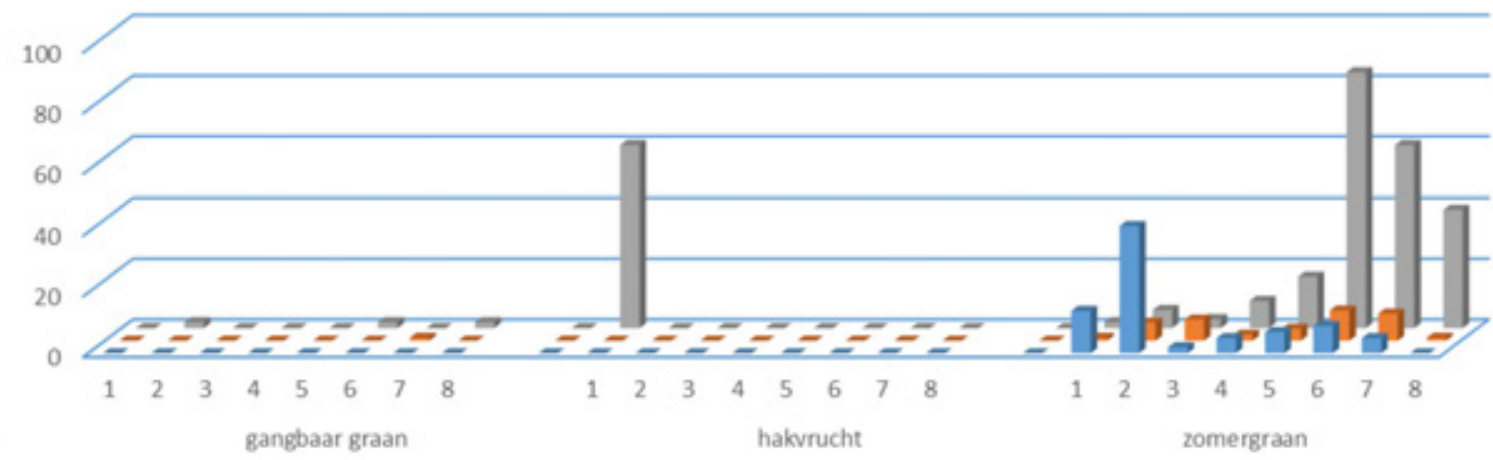

Veldleeuwerik-Veenkoloniën

jaar $=15 / 16=16 / 17=17 / 18$

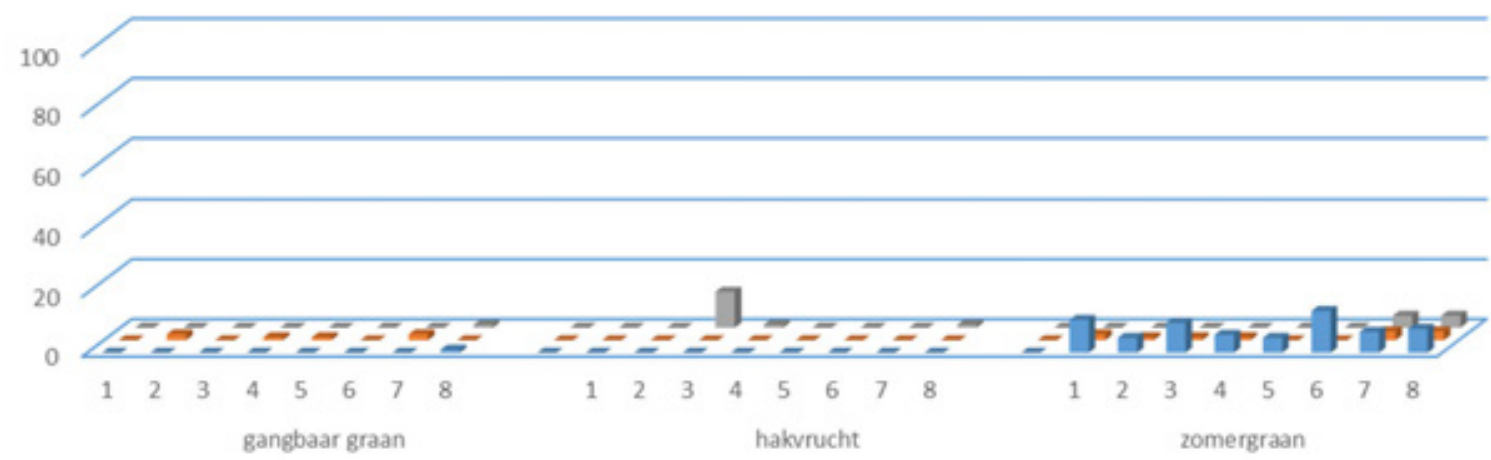

Figuur 26 Het totaal aantal veldleeuwerikken die waargenomen zijn per regio en per telronde (1 t/m 8) op de percelen gedurende de 3 winterperiodes. 


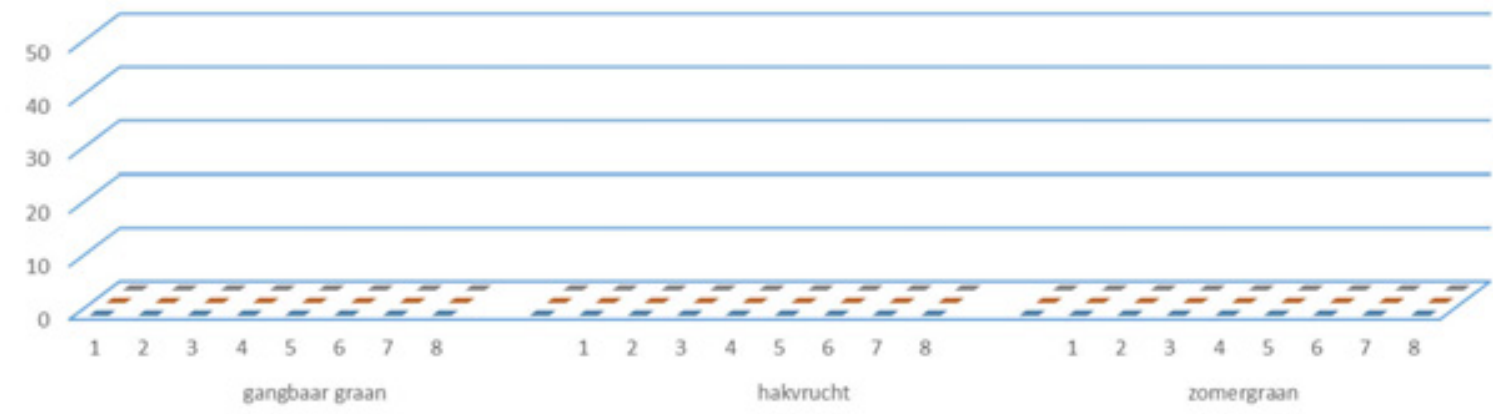

\section{Geelgors-Oldambt}

jaar $=15 / 16=16 / 17=17 / 18$

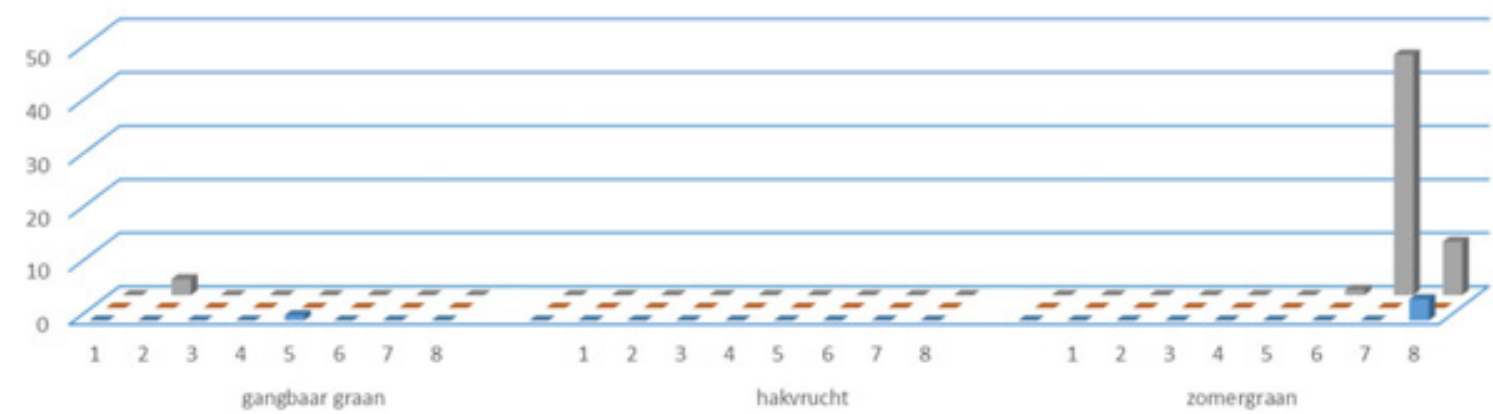

Geelgors-Veenkoloniën

jaar $=15 / 16 \quad \equiv 16 / 17 \quad=17 / 18$

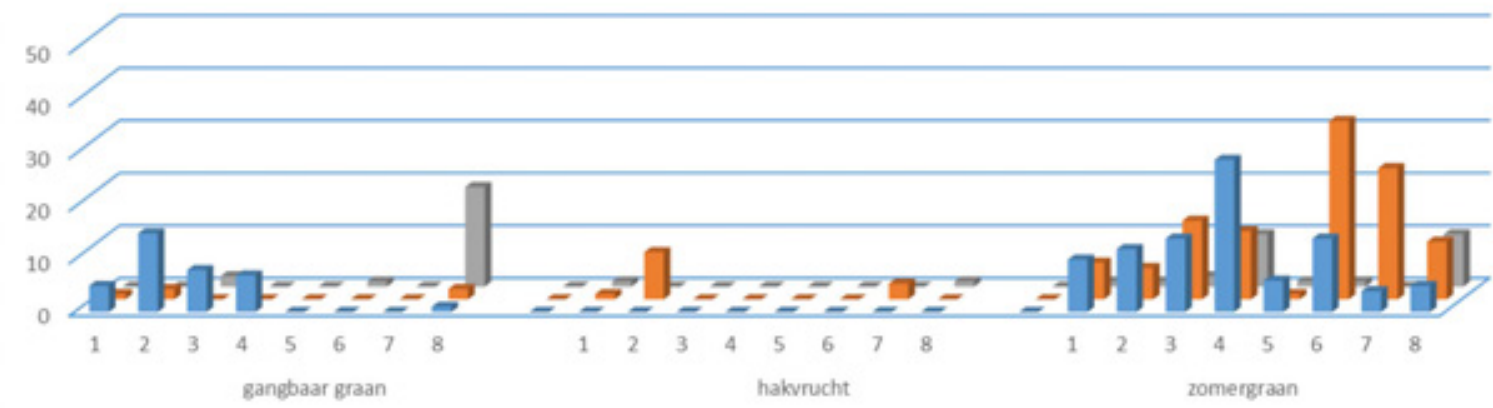

Figuur 27 Het totaal aantal geelgorzen die waargenomen zijn per regio en per telronde (1 t/m 8) op de percelen gedurende de 3 winterperiodes. 

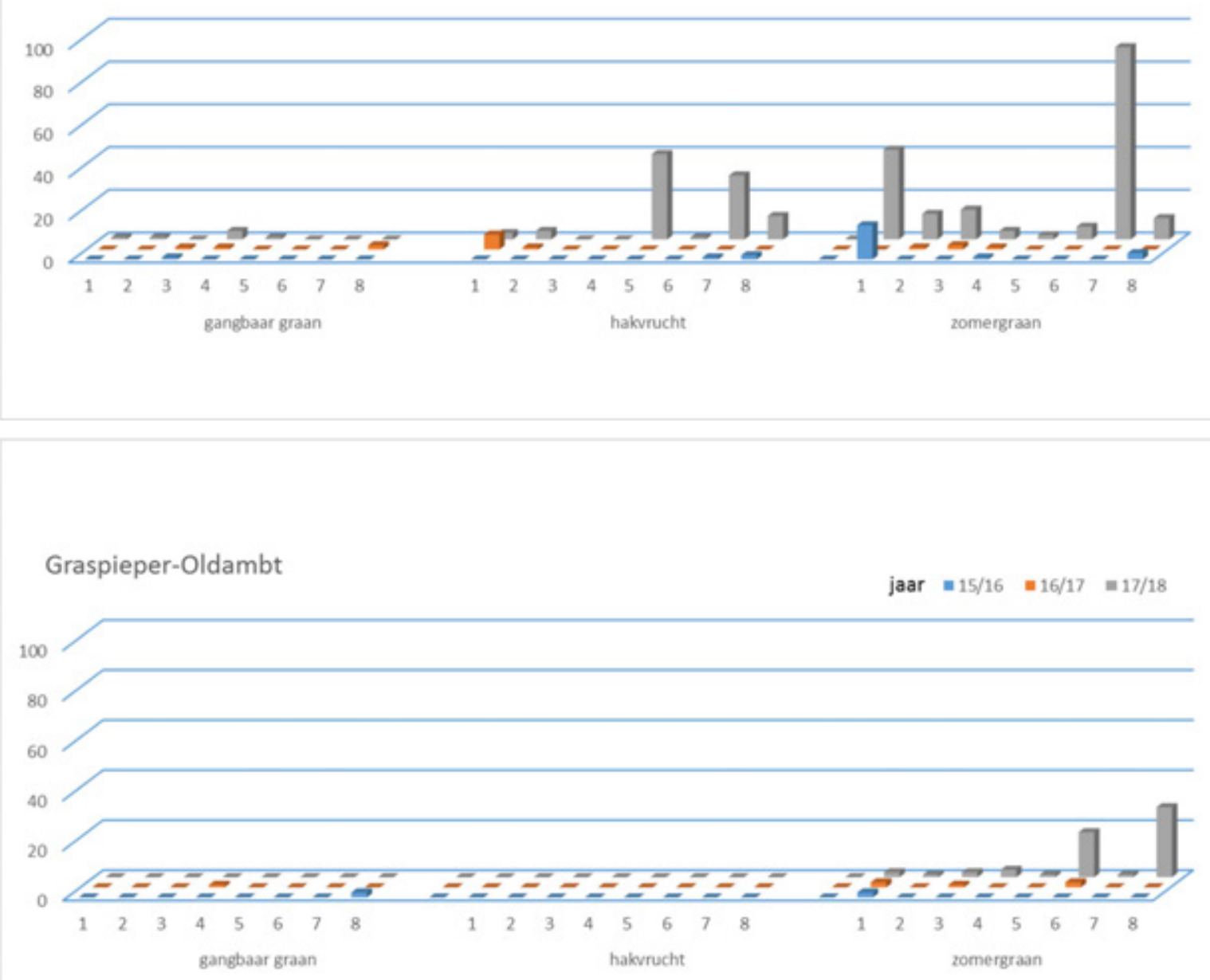

\section{Graspieper-Veenkoloniën}

jaar $=15 / 16=16 / 17=17 / 18$

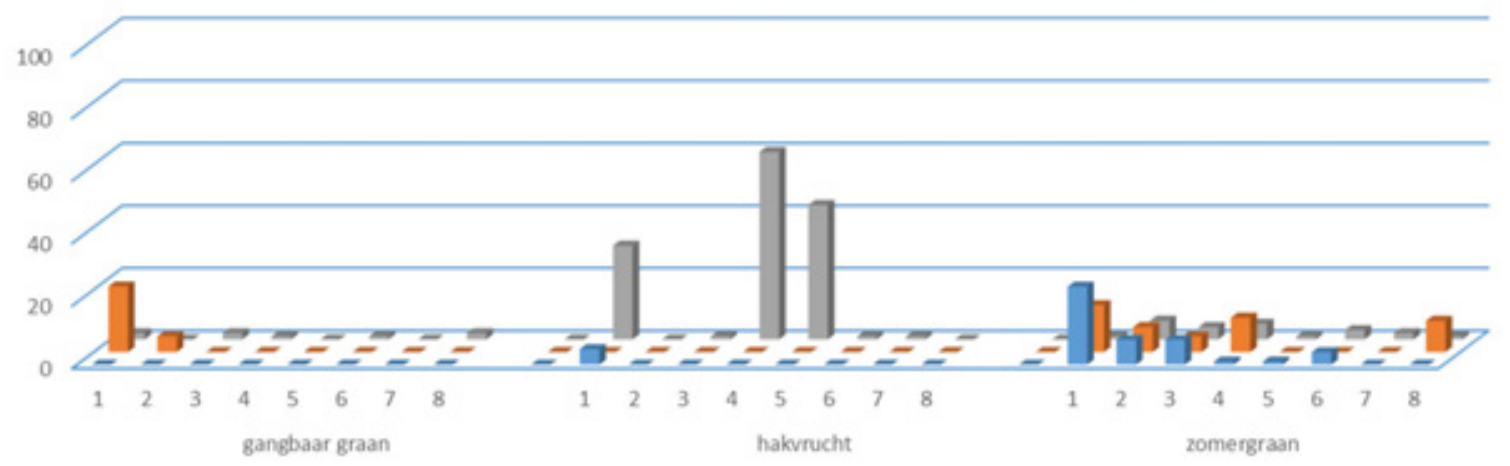

Figuur 28 Het totaal aantal graspiepers die waargenomen zijn per regio en per telronde ( $1 \mathrm{t} / \mathrm{m} 8)$ op de percelen gedurende de 3 winterperiodes. 


\section{Samenvattend}

Naast zaden eten vooral de bodem gebonden akkervogels, ook groene plantendelen. Door hun begroeiing (bloeiende) grassen en onkruiden, achtergebleven graankorrels, gewasopslag en stoppels hebben deze zomergraanstoppels een grote aantrekkingskracht op akkervogels. Een soort als de veldleeuwerik werd vooral aangetroffen op de klei in Hogeland en Oldambt in de zomergraanstoppels en in geringere mate in de zomergraanstoppel op het zand in de Veenkoloniën. Een soort als de geelgors heeft duidelijk een voorkeur voor graanstoppels op zandgrond in de Veenkoloniën. Roofvogels en reigers lijken geen echte voorkeur voor de zomergraanstoppels te hebben.

\subsection{Insecten}

Uit het oogpunt van kosten en beschikbare menskracht was het slechts mogelijk om één vangstronde van een week in de tweede helft van juni 2017 te doen. Bij de eenmalige en kortstondige insectenbemonstering stond de vraag centraal of de percelen met een beperkte herbicide behandeling/dosering een andere insectenfauna herbergen dan de controlepercelen. Om deze vragen te kunnen beantwoorden zijn alle insectenvangsten ingedeeld in drie functionele groepen:

- Insecten als voedsel voor akkervogels

- Insecten als mogelijke schadeveroorzakers in de graanteelt

- Insecten als nuttig in de graanteelt voor plaagonderdrukking.

Omdat sommige insectengroepen binnen deze functionele indeling van groter belang zijn dan andere insectengroepen, is er naast de totale vangst van die functionele groep ook gekeken naar het aandeel van de belangrijkste groepen binnen die vangst.

Er is gekozen voor een combinatie van potvallen (voor op de bodem levende dieren) en gele vangbakken (voor vliegende of door de wind meegevoerde fauna). Deze twee methoden zullen een onderschatting geven van de insecten die zich op de planten in het gewas bevinden (bladluizen, rupsen, bladhaantjes, enz.). Dat betekent dat zowel de beschikbaarheid van insecten als vogelvoer als de mogelijke aanwezigheid van plagen in het gewas worden onderschat door de gekozen bemonsteringsmethoden.

In totaal zijn 26.833 diertjes gevangen en gesorteerd in 90 verschillende taxonomische groepen (soms op het niveau van klasse of orde, vaak op familieniveau, en soms uitgesplitst in grootte-klassen en/of adulten en larven). Deze groepen zijn pragmatisch gekozen om enerzijds de hoeveelheid determinatiewerk zo beperkt mogelijk te houden, en anderzijds om het onderscheid in functionele groepen (vogelvoer, plagen of natuurlijke vijanden) zo groot mogelijk te houden. Een overzicht van de vangsten staat in Tabel 5 en 6 van Bijlage 7. Tabel 5 omvat 99,7\% van alle vangsten. De groepen waarvan geen of in totaal minder dan 10 exemplaren zijn gevangen, zijn uit Tabel 5 weggelaten en staan in Tabel 6 van Bijlage 7. De laatste groepen, met minder dan 10 exemplaren, zijn bij de verdere analyse buiten beschouwing gelaten (dat betreft 0,25\% van de gevangen 26.833 dieren).

Bij de potvallen worden de vangsten gedomineerd door spinnen (6\%), mijten (10\%), loopkevers ( $>5 \mathrm{~mm})(28 \%)$, kortschildkevers (< $5 \mathrm{~mm})(19 \%)$, overige kevers (< $10 \mathrm{~mm})(14 \%)$ en overige vliegen $(<10 \mathrm{~mm})(7 \%)$. Bij de gele vangbakken is deze laatste groep, overige vliegen $(<10 \mathrm{~mm})$, goed voor $66 \%$ van de vangsten, terwijl alle andere groepen onder de $5 \%$ van het totaal blijven.

De vangsten in de potvallen verschillen nogal tussen bedrijven, en binnen bedrijven zijn soms aanzienlijke verschillen tussen het onderzoeksperceel en het controleperceel (Figuur 29). Per perceel werden tussen de 200 en ruim 1.500 bodembeestjes gevangen. 


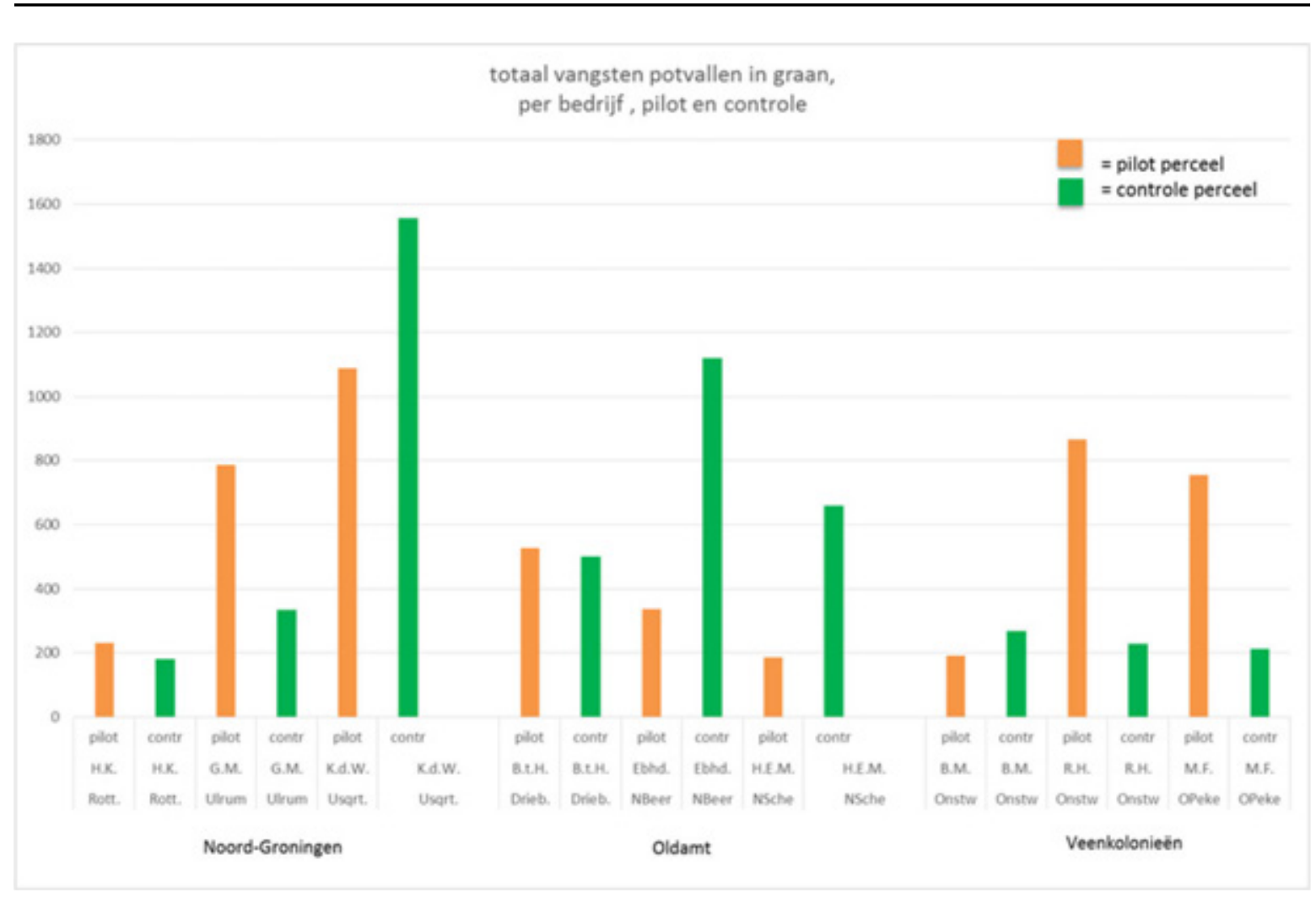

Figuur 29 Vangsten in potvallen in graanpercelen, totalen per bedrijf per onderzoeks- en controleperceel.

Ook als we kijken naar individuele insectengroepen, bestaan er grote verschillen tussen bedrijven en soms tussen de twee percelen op hetzelfde bedrijf. Zo werden op één bedrijf 131 kleine bladsprietkevers gevangen, terwijl er op de acht overige bedrijven slechts één exemplaar werd gevonden. Iets vergelijkbaars werd ook gevonden voor mijten en aaskevers. Op het onderzoeks perceel van een bedrijf werden 900 kleine "overige" kevers gevangen, terwijl op het controleperceel van het hetzelfde bedrijf slechts 4 exemplaren werden gevangen. Een dergelijk verschil werd ook gevonden voor grote loopkevers en kleine kortschildkevers op andere bedrijven. Deze grote variatie in vangsten maakt het lastig om effecten van de pilot te beoordelen.

De vangsten lijken in de Veenkoloniën, met name op de controlepercelen, op een wat lager niveau te liggen dan in de twee andere regio's.

Er zijn anderhalf maal zoveel beestjes in de gele vangbakken gevangen dan met behulp van potvallen. Zoals hiervoor aangegeven worden de resultaten van de gele vangbakken sterk gedomineerd door één groep, "vliegen overig $\leq 10 \mathrm{~mm}$ " die $66 \%$ van de totale vangsten uitmaken. Deze groep is als soms belangrijk voor vogelvoer beoordeeld en als belangrijk voor de groep plagen in granen, omdat meerdere Diptera serieuze plaagproblemen in granen kunnen veroorzaken ( $\mathrm{nl}$. diverse soorten galmuggen, fruitvlieg, graanmineervlieg, smalle graanvlieg en gele halmvlieg). 


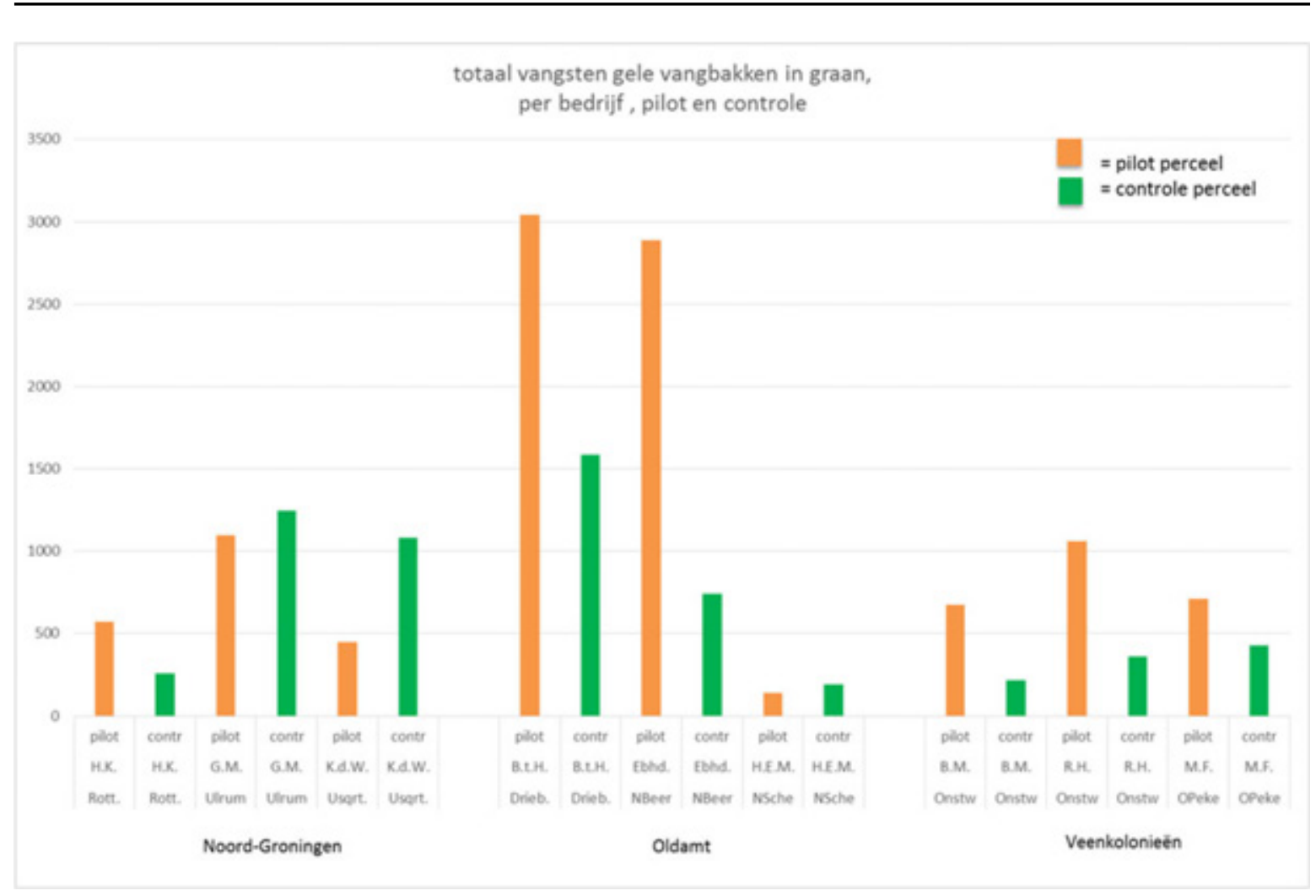

Figuur 30 Vangsten in gele vangbakken in graanpercelen, totalen per bedrijf per onderzoeks- en controleperceel. Let op de andere schaal van de Y-as dan in Figuur 29.

Op 6 van de 9 bedrijven zijn de vangsten op de onderzoekspercelen met aangepaste teelt van zomergraan hoger dan in de controlepercelen met gangbare teelt van winter- en zomergraan. Ook bij de gele vangbakken zien we enkele opvallende uitschieters. Tweederde van de groep "kevers overig $<10$ mm" (ruim 440 exemplaren) is gevangen in één pilotperceel. Van de groep "vliegen overig $<10$ mm" zijn er ruim 1800 gevangen in één onderzoeksperceel, terwijl er ook onderzoekspercelen zijn met maar 36 of 78 exemplaren (en andere percelen met alles daar tussenin).

\section{Samenvattend}

Tabel 10 geeft een samenvatting van de eenmalige insectenbemonstering, weergegeven als het aantal bedrijven waarop in het onderzoeksperceel méér insecten zijn gevangen (in verschillende functionele groepen) dan in het controleperceel op hetzelfde bedrijf. Voor meer details zie bijlagen 7.

Uit de resultaten kan (voorzichtig) de conclusie worden getrokken dat een verminderde inzet van herbiciden en insecticiden in de onderzoekspercelen een positief effect lijkt te hebben op het insectenleven. Er worden vaker meer exemplaren gevangen van insectengroepen die belangrijk zijn als vogelvoer en als natuurlijke vijanden van plagen, zowel in de potvallen als in de gele vangbakken (Tabel 10). Dat geeft voldoende aanwijzingen om dit onderzoek op een grotere schaal te herhalen.

Tabel 10 Samenvatting van de resultaten van de insectenbemonsteringen. Het aantal bedrijven waarop in het onderzoeksperceel méér insecten zijn gevangen (in verschillende functionele groepen) dan in het controleperceel op hetzelfde bedrijf.

\begin{tabular}{|c|c|c|}
\hline & Potvallen & Gele vangbakken \\
\hline & $\begin{array}{c}\text { \# bedrijven }(n=9) \\
\text { onderzoek }>\text { controle* }\end{array}$ & $\begin{array}{c}\text { \# bedrijven }(n=9) \\
\text { onderzoek > controle* }\end{array}$ \\
\hline - Vogelvoer - totaal & 4 & 6 \\
\hline - Vogelvoer - belangrijke groepen & 7 & (8) \\
\hline - Natuurlijke vijanden -totaal & 6 & (8) \\
\hline - natuurlijke vijanden - belangrijke groepen & 7 & (7) \\
\hline
\end{tabular}

$*$ = Waarden tussen (..) zijn gebaseerd op relatief geringe vangsten, en moeten daarom met voorzichtigheid worden gewaardeerd. 


\section{$4 \quad$ Praktijkervaringen met uitvoering van de pilot}

Door het late tijdstip in groeiseizoen 2015 waarop de financiering van het project rondkwam, moest de werving van deelnemers heel snel gebeuren en een aantal van de deelnemers had op het beoogde onderzoeksperceel inmiddels de grondbewerking al uitgevoerd en soms ook al ingezaaid. Daardoor hebben in het eerste jaar niet alle deelnemers het onderzoek helemaal volgens voorschriften kunnen uitvoeren. Voordeel is nu wel dat de variatie in uitgangssituatie en bewerkingen groot is, daardoor staat het onderzoek garant voor de brede verscheidenheid die in de praktijk wordt aangetroffen.

De voorgeschiedenis van een perceel (het gebruik, teeltplan en evt. rijschade in voorgaande herfst) en de ligging van het perceel in het landschap, bepalen in sterke mate de uitgangsituatie in onkruiddruk. Een perceel waarop jarenlang een akkervogelbeheerpakket heeft gelegen, zal een andere akkeronkruidengemeenschap hebben dan een gangbaar akkerbouwperceel waar jaarlijks de onkruiden bestreden zijn. De onkruiddruk zal er ook hoger zijn. Dit was ook duidelijk te zien op het perceel van $\mathrm{KdW}$, waar op het onbespoten perceelsgedeelte de onkruiddruk in 2015 al hoog was. Bij HK was in 2015 de zaaibedbereiding slecht gelukt, waardoor het gewas slecht ontwikkelde (Figuur 7). Groningen bestaat uit drie sterk van elkaar verschillende landbouwgebieden, het Hogeland met lichte kleigrond, het Oldambt met zware kleigrond en het veenkoloniale gebied met zandgrond. In hoofdstuk 3.2 zagen we al dat de onkruiddruk op de drie bedrijven in de Veenkoloniën hoger was dan op de bedrijven op kleigrond.

Tijdens evaluatiebijeenkomsten met de deelnemers zijn op 17 februari 2016, 31 januari 2017 en 23 april 2018 de ervaringen van de deelnemers met de teelt van zomergraan gedeeld. Alle deelnemers constateren al na het eerste jaar een sterke toename in veronkruiding op de perceelsgedeelten waar helemaal geen gewasbescherming mocht worden toegepast en gaven aan dat geheel niet spuiten geen optie zou zijn. Tijdens een veldbezoek op 1 juli 2016 waarin een aantal deelnemers gezamenlijk met de projectleiding en opdrachtgever een ronde maakten over de onderzoekspercelen is geconstateerd dat de behandeling helemaal niet spuiten geen haalbare kaart is en werd besloten in het derde proefjaar deze variant te laten vervallen. De observaties van de deelnemers werden ondersteund door de resultaten van de onkruidmonitoring.

In de evaluatiebijeenkomsten werd ook geconstateerd dat op de meeste bedrijven een beperkt herbicidegebruik inpasbaar is in de bedrijfsvoering. De aangepaste teelt van zomergraan met beperkte grondbewerking, lagere zaaidichtheid en beperkt gebruik van gewasbescherming resulteerde echter in een lagere graanopbrengst in vergelijking met de gangbare teelt van wintergraan.

Er zijn tijdens de evaluatiebijeenkomsten door de deelnemers een aantal suggesties aangedragen op welke wijze de grondbewerking voorafgaand aan de inzaai van 2016 en 2017 verbeterd kon worden en hoe na de oogst de stoppelbewerking kon worden uitgevoerd.

Een opvallende uitkomst van dit eerste jaar was dat ondanks de verschillen in grondbewerking, zaaitijdstip, gebruikte zaaizaadhoeveelheden, toegepaste gewasbescherming en waargenomen onkruiddruk de verschillen in gewasopbrengst (uitgedrukt in ton graan per ha) betrekkelijk gering waren (Tabel 7). Geen van de deelnemende bedrijven rapporteerde ernstige teeltproblemen in het eerste jaar van de pilot. In het tweede jaar (2016) waren de graanopbrengsten veel lager en ver uiteenlopend, dit varieerde van 1,2 tot 7,3 ton/ha. Hier lijkt sprake van een jaareffect, maar een aantal deelnemers bleek de teelt van zomergraan ook nog niet helemaal in de vingers te hebben. Op basis van de ervaringen van deze twee jaren werd in het derde jaar (2017) de teelt van zomergraan verder geoptimaliseerd. 


\subsection{Beperkingen van deze proefopzet}

\section{Teelten}

Dit onderzoek moet gezien worden als een praktijkproef waarbij al lerende een extensievere teelt van zomergranen werd ontwikkeld met als doel een beter biotoop voor akkervogels te bieden. De spreiding tussen de bedrijven in de wijze waarop de zomergranen werden geteeld was zeer groot, dat gold voor de grondbewerking, bemesting en teelt (graansoort, inzaaitijdstip, zaaizaadhoeveelheid en oogstdatum), het gebruik van gewasbeschermingsmiddelen en de bewerking van de stoppels na de oogst. Dit is echter inherent aan een praktijkproef die in verschillende regio's en op verschillende grondsoorten werd uitgevoerd. Deze spreiding in wijze waarop geteeld werd, zorgde voor grote variatie in resultaten, dat maakte de interpretatie soms lastig. Wel geeft de spreiding in deze praktijkproef goed de variatie weer die in de praktijk verwacht kan worden in opbrengst, onkruidontwikkeling en vogelpopulatie op bouwland in Groningen.

Bij de interpretatie van de resultaten moet de lezer zich realiseren dat deze proef niet op een proefveld heeft plaatsgevonden. De bedrijven vormden geen zuivere herhalingen en binnen een bedrijf was er vaak ook een aanzienlijke variatie in teeltwijze tussen de jaren. De resultaten geven duidelijke signalen, maar geen statistisch betrouwbaar bewijs.

\section{Akkervogelonderzoek}

Bij de opzet van het broedvogelonderzoek waren we ons al bewust van de beperkingen die veroorzaakt worden door de geringe grootte van de onderzoekspercelen en de mogelijke onderlinge beïnvloeding van onderzoeks- en controlepercelen als deze dicht bij elkaar liggen. Van te voren was duidelijk dat het niet goed mogelijk zou zijn om vast te stellen of de gedane waarnemingen eenduidig aan de onderzoeks- of controlepercelen gerelateerd konden worden. De meeste akkervogels hebben een territorium dat in veel gevallen groter is dan de onderzoekspercelen zelf. De aan- of afwezigheid van extensieve landschapselementen of de gewasteelt speelt bovendien een belangrijke, zo niet beslissende rol in de vestiging van broedende akkervogels. Gekozen is hierdoor voor een transecttelling en heeft er geen, voor Nederland zeer gangbaar, BMP-onderzoek plaatsgevonden. De waarnemingen zijn ook niet herleid tot territoria wat in een BMP-onderzoek wel wordt gedaan. De verzamelde waarnemingen met relevante broedcode zijn wel ruimtelijk geanalyseerd. Hiermee is een goede indicatie verkregen of en hoe akkervogels gebruik maken van de onderzoeks- en controlepercelen. Om de waarnemingen ecologisch te borgen in het landschap is gebruik gemaakt van een buffer van 50 meter rondom de percelen.

\section{Insectenonderzoek}

Elke bemonsteringsmethode voor insectendiversiteit en -dichtheden is selectief en representeert slechts een schatting van de werkelijkheid. Uit het oogpunt van kosten en beschikbare menskracht werd gekozen voor een combinatie van potvallen (voor op de bodem levende dieren) en gele vangbakken (voor vliegende of door de wind meegevoerde fauna). Bovendien was het slechts mogelijk om één vangstronde van een week in de tweede helft van juni 2017 te doen; dus de resultaten vormen een momentopname uit een heel groeiseizoen.

Een andere beperking is dat deze twee methoden geen goed beeld geven van de insecten die zich op de planten in het gewas bevinden (bladluizen, rupsen, bladhaantjes, enz.). Dat betekent dat zowel de beschikbaarheid van insecten (als voer voor vogels) als de mogelijke aanwezigheid van plagen in het gewas onderschat kunnen zijn door de gekozen bemonsteringsmethoden.

Het gewasbeschermingsmiddelengebruik in gangbaar geteelde winter- en zomergranen verschilde van die in zomergraan met beperkte inzet van gewasbeschermingsmiddelen. Zo waren insecticiden op de onderzoekspercelen niet toegestaan. Echter in 2017 is slecht op 3 bedrijven in de controlepercelen met granen een insecticide gebruikt. Daardoor verschillen in dat jaar dus maar 3 van de 9 percelen van de gangbaar geteelde granen met die van zomergraan met beperkt gebruik van 
gewasbescherming. Door de beperkte opzet geeft het insectenonderzoek slechts een indicatie, wel geven deze waarnemingen een uitgebreid inzicht van de insectenpopulatie in zomergraan in vergelijking met wintergraan.

\subsection{Betekenis van akker(on)kruiden voor zaadetende vogels}

Dit onderzoek laat duidelijk zien dat een aangepast bouwplan met een driejarige teelt van zomergraan een onkruidvegetatie kan opleveren die waarde heeft voor akkervogels. Door minder inzet van chemie en een door minder dicht inzaaien (waardoor een opener gewasstructuur ontstaat), krijgen akkerkruiden meer kans zich te vestigen in tegenstelling tot gangbaar geteeld wintergraan dat dicht gezaaid wordt en weinig ruimte laat voor de ontwikkeling van akkerkruiden. De meest voorkomende en meest talrijke soorten komen uit de familie van de duizendknoop en ganzenvoet. Soorten uit deze families komen op zowel klei- als zandgrond veelvuldig voor en leveren volop zaden die akkervogels (kneu, geelgors, rietgors en veldleeuwerik) eten. Maar ook de zaden van een soort als duist worden vooral door rietgorzen gegeten (Clarke et al., 2003). Op zandgrond is daarnaast vogelmuur een soort die veel voorkomt en ook een zeer geschikte voedselbron vormt voor veel akkervogels. De vraag is echter of deze zaden beschikbaar zijn op het moment dat vogels daar behoefte aan hebben. Als er in mei, begin juni gespoten wordt met herbiciden, dan zijn er in de zomermaanden maar beperkt zaden beschikbaar van deze akkeronkruiden. Voor het groot brengen van de jongen zijn in deze periode vooral insecten van belang.

In de nazomer, herfst en winter is er in veel akkerbouwgebieden met gangbare teelten weinig voedsel beschikbaar, zeker voor doortrekkende en overwinterende akkervogels. Graanstoppels kunnen dan een belangrijke rol vervullen in het aanbod van zaden. De waarde van soorten uit de duizendknoop en ganzenvoetfamilies in de stoppel is in de winter gering, omdat deze soorten dan nog maar in zeer beperkte mate aanwezig zijn in de stoppel. Straatgras daarentegen komt wel volop in de stoppel voor, is zaaddragend en biedt 's winters een goede voedselbron. Daarnaast zijn de groene delen van grassen, opslag van graan en akkerkruiden aantrekkelijk voor sommige akkervogelsoorten zoals de veldleeuwerik, geelgors en rietgors. Naast voedsel bieden de graanstoppels, daar waar ze begroeid zijn met gewasopslag en grassen, dekking in het overwegend kale (geploegde) land. Ook dat is een belangrijke waarde van begroeide graanstoppels in de winter.

\subsection{Meerwaarde van driejarige teelt met zomergranen en overwinterende stoppels voor akkervogels}

\section{Veldleeuwerik}

In de Groningse akkerbouwgebieden heeft de veldleeuwerik altijd een prominente rol gespeeld. In de hoogtijdagen bestonden de meeste agrarische bedrijven uit een combinatie van veeteelt en akkerbouw; het zogenaamde gemengd bedrijf dat nu vrijwel is verdwenen. Zeer hoge dichtheden werden gehaald in een landschap dat bestond uit extensieve hooilandjes, kleine akkerbouwpercelen met een hoge variatie aan gewassen en een trage sterk gefaseerde mechanische grondbewerking. De veldleeuwerik kwam in Groningen ook voor op extensief grasland buiten de akkerbouwgebieden maar kon zich daar niet meer handhaven vanwege de steeds hogere maaifrequenties en vroegere maaibeurten. Dit komt door een betere ontwatering en zwaardere bemesting waarmee de grasgroei vroeger op gang komt en er veel eerder gemaaid kan worden. De veldleeuwerik beperkt zich vandaag de dag vrijwel exclusief tot de Groningse akkerbouwgebieden (Wiersma et al., 2014). In Groningen zijn de dichtheden op de zandgronden hoger dan op de klei (Wiersma et al., 2014). Waarschijnlijk heeft dat te maken met de teelt van zomergranen en hakvruchten die tot laat in het voorjaar voldoende open blijven en waarbij veel kale bodem beschikbaar blijft waar op grondinsecten gejaagd kan worden. Wintergranen zijn al vroeg in voorjaar te dicht voor veldleeuweriken. Mogelijk komen hierdoor de zomergraanpercelen op de zware kleigrond in het Oldambt beter uit de resultaten dan de zomergraanpercelen in de Veenkoloniën. Dit kan duiden op een positief effect van de teelt van zomergranen in een door wintergranen gedomineerd landschap. Het verlies aan areaal van 
zomergranen is als oorzaak genoemd voor de sterke achteruitgang van de veldleeuwerik in afgelopen decennia (Bos et al., 2010). Een aanbod van extensief geteelde zomergraan lijkt mede daarom een gunstige maatregel ter versterking van het leefgebied voor de veldleeuwerik.

\section{Gele kwikstaart}

De gele kwikstaart lijkt op de klei van het Hogeland en het Oldambt niet echt te profiteren van de teelt van zomergranen. De teelt van gangbare wintergranen zorgt hier voor voldoende geschikt leefgebied waar de omvangrijke Groningse populatie zich goed in staande kan houden.

De late eileg van de gele kwikstaart, zo rond eind april of begin mei, zorgt bovendien voor weinig legselverliezen door grondbewerkingen of sleepslangen in april. Wintergranen bieden dan bovendien al voldoende dekking waar zomergranen dat nog niet altijd doen. Voor vervolglegsels is de zomertarwe waarschijnlijk wel geschikt.

\section{Rietgors}

De rietgors is eigenlijk geen akkervogel, de aanwezigheid van deze vogel is altijd gerelateerd aan water in combinatie met ruigtekruiden en bij voorkeur wat riet. De waarnemingen in het Hogeland hebben waarschijnlijk te maken met een langjarig rietproject (Kaantjes en Raandjes) van de ANV Wierde \& Dijk. Dit project had als doel om op het Hogeland in samenwerking met andere gebiedspartijen riet in kleisloten te stimuleren en te ontwikkelen (Wierde \& Dijk, 2012). Gezien de opvallende verschillen tussen het Hogeland en het Oldambt, zou het afwezig zijn van de rietgors in het Oldambt dus mogelijk een effect van al te rigoureus slootschonen kunnen zijn.

De waarnemingen uit de Veenkoloniën kunnen op het conto worden geschreven van een perceel dat tegen een waterrijk natuurgebied aan ligt. Zie ook de hoge aanwezigheid in de buffer. De teelt van extensieve zomergranen in de nabijheid van overstaand waterriet zal zeker van meerwaarde zijn voor de rietgors in met name de winterperiode wanneer de stoppel overwintert.

\section{Graspieper}

Over het algemeen zijn er maar weinig graspiepers waargenomen. Het is daarom niet goed mogelijk om de teelt van zomergraan als gunstig te betitelen voor het leefgebied van de graspieper.

Vermoedelijk zijn de hoge aantallen in het gangbare graan te wijten aan de ligging nabij matig onderhouden kleipaden of andere reliëfrijke plekken in het landschap. Indien zomergraan op de onderzoekspercelen naast vergelijkbare landschapsstructuren zou worden geteeld, dan zou dat zeer waarschijnlijk ook gunstig voor de graspieper uitpakken.

\section{Kneu}

De voorkeur van de kneu komt mooi uit de resultaten naar voren. Het Hogeland dichtbij de kust en het kleinschalige landschap in de Veenkoloniën zijn duidelijk favoriet. In de grootschalige openheid van het Oldambt werden maar een paar vogels geteld. De teelt van zomergraan kan voor de kneu van meerwaarde zijn mits er voldoende akkerkruiden tussen het zomergraan opkomen. Een perceel zonder enige akkerflora heeft geen meerwaarde voor de kneu. De verklaring voor de hoge broedcodes die ook in het gangbare geteelde graan zijn vastgesteld, zal waarschijnlijk gezocht moeten worden in de ligging van deze percelen naast bermen of erven waar voldoende zadenrijke planten groeien.

\section{Geelgors}

De geelgors doet het goed in de oostelijke helft van Groningen (Koole \& Spoel van der, 2015). In Westerwolde richten natuurorganisaties zich op het herstel van het kleinschalig akkerbouwlandschap (Koole, 2015) en ook het aanbod van overstaand graan in het kader van het agrarisch natuurbeheer (Wiersma et al., 2014) speelt vermoedelijke een belangrijke rol in dit succes. De zware klei wordt alleen aan de oostkant van Groningen bezet (Nederlandse Fauna 5, 2002). Het enkele vastgestelde territorium in het Oldambt is hier een mooi voorbeeld van.

Op het Hogeland hebben tot in de jaren vijftig van de vorige eeuw geelgorzen gebroed (Hoff van 't, 2010) maar nu worden alleen in de winterperiode bescheiden aantallen waargenomen (Koole, 2017). Een extensieve teelt van zomergraan op de zware klei zou gunstig kunnen zijn voor een meer noordwestelijke verspreiding, helemaal als dit zou samengaan met de aanplant van struiken, heggen of hagen. Belangrijke voorwaarde is bovendien dat het zomergraan tot laat in het seizoen voldoende open blijft zodat op de bodem gefoerageerd kan worden. Deze voorkeur voor een kale bodem kwam ook mooi tot uiting in de Veenkoloniën waar hakvruchten boven granen werden verkozen. 


\section{Ringmus}

Voor de ringmus is een kruidenrijke teelt van granen en overblijvende winterstoppels van cruciaal belang voor de populatieontwikkeling. De sterke voorkeur voor de zomergraanpercelen onderstreept dit nogmaals. Mogelijk profiteert de soort ook van het aanbod van nestkasten bij woonkernen in het agrarisch gebied. Maar gezien de aantalsontwikkeling van de afgelopen decennia (Nederlandse Fauna 5 , 2002) lijkt dit maar een gering effect te hebben. De ringmus heeft baat bij uitgebreide beschermingsmaatregelen waarbij vooral voldoende nestgelegenheid naast het aanbod van voedsel een belangrijke rol speelt.

\section{Kwartel}

De dichtheid aan kwartels kan jaarlijks fluctueren, goede jaren worden afgewisseld met mindere jaren en invasies kunnen ook nog laat in het seizoen plaatsvinden. Dit wordt mogelijk veroorzaakt door broedsucces elders in Europa. Want deze nieuwe aanwas kan in hetzelfde broedseizoen ook weer elders zorgen voor nieuwe legsels (Cramp \& Simmons, 2004). Kwartels kunnen zich in het broedseizoen over grote afstanden verplaatsen. Ook is niet met zekerheid te zeggen of roepende mannetjes plaatstrouw blijven. Ongepaarde kwartels blijven roepen en leggen dan flinke afstanden af. Het is bovendien een soort met een hele lage trefkans omdat na paarvorming de mannetjes niet meer roepen. De kwartel is een mooie maar lastige doelsoort. Kruidenrijk zomergraan in combinatie met een klei- of zandpad zou voor de kwartel zeker een versterking van het leefgebied zijn.

\section{Fazant}

De dichtheden zijn zo laag dat er nauwelijks conclusies aan te verbinden zijn. Mogelijk heeft de soort de afgelopen jaren een forse aderlating ondergaan. De aanstaande broedvogelatlas van SOVON zal daar uitsluitsel over kunnen geven. Waarschijnlijk biedt het zomergraan de fazant wel een goed leefgebied in het broedseizoen om er in te foerageren op insecten als voer voor de jongen. In combinatie met enigszins verruigde akkerranden als broedplek zou de teelt van zomertarwe het leefgebied van de fazant kunnen versterken.

\section{Algemeen voor akkervogels}

Het aantal en de soorten (akker)vogels die in de winter de percelen bezoeken om er te foerageren hangt sterk af hoe deze percelen er op dat moment bij liggen. Op kale geploegde akkers is weinig dekking en valt er weinig te halen aan voedsel. Voor zaadetende vogels zijn vooral de graanstoppels met opslag van granen en akkeronkruidbegroeiing aantrekkelijk. Hier vinden ze dekking tegen roofvogels en valt er aan zaden en groene delen volop voedsel te vinden. Ook de percelen waar hakvruchten hebben gestaan, scoren redelijk goed. Ook hier zullen gewasresten en mate van begroeiing een rol spelen of akkervogels er in de winter neerstrijken. De aantallen en soorten die zijn aangetroffen variëren sterk gedurende het winterseizoen, afhankelijk van o.a. de vogeltrek en weersituatie.

Zomergranen met een meer open gewasstructuur en enige mate van onkruidbegroeiing is ook aantrekkelijker voor insecten. De bodem warmt sterker op en er is een meer gevarieerde begroeiing. Door geen insecticiden te gebruiken kunnen meer insecten overleven en een voedselbron vormen voor akkervogels om hun jongen in het broedseizoen groot te brengen.

\subsection{De landbouwkundige waarde van een driejarige teelt met zomergranen en de inpasbaarheid in de bedrijfsvoering}

Groningse akkerbouwers raakten in afgelopen jaren steeds minder gemotiveerd om akkervogelpakketten in hun bouwplan op te nemen. Het randenbeheer dat in veel agrarisch natuurbeheerpakketten centraal stond leverde te veel gedoe op, was inflexibel en zorgde voor problemen met lastige onkruidsoorten als akker- en melkdistel, duist en bijvoet (Van Wees, 2016). Aan de andere kant zijn veel akkerbouwers bezorgd over het verdwijnen van akkervogels van hun land. Dat was reden om na te denken over een beheer dat betere kansen biedt voor akkervogels en ook beter inpasbaar is in de bedrijfsvoering. Negen akkerbouwers verspreid over de provincie 
Groningen hebben op initiatief van de ANV's Wierde \& Dijk en ANOG ieder op twee ha drie jaar achtereen zomergraan geteeld. Daarbij werd minder zaaizaad gebruikt dan gewoonlijk om een wat opener gewas te creëren, slechts op beperkte schaal gewasbeschermingsmiddelen te gebruiken en de stoppel de winter over te laten liggen. Uit de resultaten bleek dat bij een aangepaste teelt van zomergraan op klei een opbrengst van 6 ton/ha reëel. Voor zand lijkt een opbrengst 5 ton per ha haalbaar. In vergelijking daarmee: op klei zijn de opbrengsten van gangbaar geteelde wintertarwe in Hogeland en Oldambt 9 á 10 ton en in de Veenkoloniën op zand voor gangbaar geteelde zomergranen ruim 6 ton. Dat is een aanzienlijk verschil.

Uit de onkruidmonitoring blijkt dat de onkruiddruk in het derde jaar in de zomergraanpercelen met een beperkt gebruik van herbiciden op zandgrond aanzienlijk groter is dan op de klei. De onkruidbedekking op de 6 bedrijven op de klei op het Hogeland en Oldambt bleef onder de $10 \%$ bedekking, waarbij die op de bedrijven op zand in de Veenkoloniën tussen de 20 en $50 \%$ lag. In het algemeen vonden de deelnemers op kleigrond de onkruidontwikkeling dan ook acceptabel, terwijl de deelnemers op zand zich toch wel zorgen maakten.

In deze pilot bleek duidelijk uit de resultaten dat de duur van drie jaar een goede keuze was. Pas in het derde jaar bleek dat de deelnemers de teelt in de vingers kregen voor wat betreft zaaidichtheid en lichte grondbewerking na de oogst. Dat wil niet zeggen dat in een toekomstig zomergraanpakket dit altijd drie jaar achtereen op hetzelfde perceel geteeld moet worden. Op zware klei zou je kunnen starten met de stoppel van de voorgaande wintertarwe. Op bedrijven met een bouwplan met zetmeelaardappelen wil men een nauwere rotatie in het bouwplan (1:1 of 1:2) kunnen toepassen, daarin past drie jaar achtereen zomergraan op het zelfde perceel niet. Voor akkervogels is het vooral van belang dat op een bedrijf voldoende graanstoppelvelden in de winter aanwezig zijn.

In de bespreking op 23 april 2018 met de deelnemers is afgesproken dat de ANV's Wierde \& Dijk en ANOG op grond van de uitkomsten uit deze pilot een voorstel zullen ontwikkelen voor een nieuw agrarisch natuurbeheerpakket. 


\section{$6 \quad$ Conclusies}

De teelt van zomergraan is niet gangbaar in het bouwplan op de klei in Hogeland en Oldambt, hier worden vooral wintergranen geteeld. In Tabel 11 is per onderdeel een waardering gegeven van deze extensieve wijze van zomergraanteelt. Vooral aan de landbouwkundige kant is er sprake van opbrengstderving en is deze ook negatief beoordeeld. Vooral de opbrengst van de op deze wijze geteelde zomergranen blijft aanzienlijk achter bij de gangbare teelt van wintergranen.

Tabel 11 Eindwaardering voor akkervogels, landbouwkundige waarde en insecten.

\begin{tabular}{|c|l|}
\hline$+/-$ & Broedende akkervogels \\
\hline+ & Overwinterende (akker)vogels (stoppel) \\
\hline- & Onkruiddruk \\
\hline- & Gewasopbrengst graan \\
\hline+ - & Kwaliteit graan \\
\hline+ & Onkruid(zaden) als voer voor akkervogels \\
\hline+ & Insecten als voer voor akkervogels \\
\hline+ & Geen toename plaaginsecten \\
\hline+ & Toename natuurlijke vijanden bladluizen \\
\hline
\end{tabular}

Een beperkt gebruik van gewasbeschermingsmiddelen biedt ruimte voor onkruidontwikkeling van veel akkeronkruidsoorten die geschikt voedsel (vooral zaden) leveren voor akkervogels. De waarde van deze onkruiden in het broedseizoen is beperkt, maar vooral de stoppels van de zomergranen in het winterseizoen hebben een grote meerwaarde voor akkervogels. $\mathrm{Er}$ is indicatie op basis van het insectenonderzoek dat ook de insectenpopulatie groter is bij deze wijze van zomergraanteelt in vergelijking met gangbaar geteelde wintertarwe.

\section{Kanttekening bij het onderzoek}

$>$ Dit onderzoek moet gezien worden als een praktijkproef waarbij al lerende een extensievere teelt van zomergranen werd ontwikkeld met als doel een beter biotoop voor akkervogels te bieden. De spreiding tussen de bedrijven in de wijze waarop de zomergranen werden geteeld was zeer groot. Dit is echter inherent aan een praktijkproef zoals die in verschillende regio's en op verschillende grondsoorten werd uitgevoerd. Deze spreiding zorgde voor grote variatie in resultaten, maar geeft ook goed de variatie weer die in de praktijk verwacht kan worden in opbrengst, onkruidontwikkeling en vogelpopulatie op bouwland in Groningen.

$>$ Een beperking van de pilot percelen voor broedvogelonderzoek was dat de percelen klein waren en daardoor de randeffecten groot.

$>$ Doordat het insectenonderzoek heel beperkt was van opzet mag dit onderzoeksdeel slechts als indicatie worden gezien.

$>$ Niet kerende grondbewerking moet geleerd worden en het duurt een aantal jaren voordat ondernemers dat in de vingers hebben en dat resultaten in opbrengst en biodiversiteit zichtbaar worden.

\section{Landbouwkundige waarde}

$>\mathrm{Er}$ is een duidelijk regioverschil in onkruidproblematiek tussen de kleigebieden en het zandgebied in de veenkoloniën. De onkruiddruk is op zandgrondduidelijk hoger bij deze wijze van teelt van zomergranen dan op de klei. 


\section{Waarde voor akkervogels}

$>$ Openheid of een meer gesloten landschap bepaalt in sterke mate het voorkomen van bepaalde akkervogels.

$>$ Een open zomergraangewas, zoals dat gerealiseerd is door een andere rijafstand en minder zaaizaad, biedt kansen voor onkruidontwikkeling en maakt het voor sommige akkervogels een aantrekkelijk biotoop t.o.v. een sterk gesloten wintergraan.

$>$ De akkeronkruidvegetatie in de zomergranen in de 3 regio's herbergt veel soorten die geschikt voedsel (zaden en groene delen) leveren. Vooral duizendknoop- en meldesoorten, maar ook straatgras en vogelmuur zijn belangrijke zaadleveranciers voor akkervogels.

$>$ In de broedseizoen was het aandeel akkeronkruiden op veel percelen gering, omdat er toch werd gespoten tegen dicotylen. Akkervogels zijn in de periode vooral afhankelijk van insecten om hun jongen mee te voeden. Een soort als straatgras is vanwege zijn zaden op dat moment nog wel belangrijk als voedselbron voor volwassen akkervogels.

$>$ Uit de monitoring van broedende akkervogels is niet direct een conclusie te trekken dat de zomergranen beter scoren dan gangbaar geteelde wintertarwe. Per soort en per regio zijn de aantallen verschillend, mede door verschillen in landschapstypen.

$>$ Geen gebruik van insecticiden lijkt gunstig voor de aanwezigheid van insecten (als voedsel voor akkervogels). Echter een vergelijking met gangbaar wintertarwe is lastig omdat in 2017 op slechts 3 bedrijven bij gangbaar geteelde winter- en zomergranen een insecticide werd gebruikt.

$>$ Insecten zijn in de zomermaanden belangrijker dan zaden voor akkervogels, vooral om de jongen daarmee groot te brengen. In de nazomer, herfst en winter zijn zaden en groene delen belangrijk. De stoppel heeft dan een belangrijke functie. Het aandeel van dicotylen in de stoppel is beperkt. Vooral straatgras lijkt een soort die veel zaden kan bieden.

$>$ Naast zaden en insecten zijn groene delen ook erg belangrijk voor overwinterende akkervogels. De stoppel biedt die volop.

$>$ De stoppel lijkt dan ook het belangrijkste 'wapen' in het voorgestelde bouwplan. Juist op het moment dat er gebrek is aan voedsel en vrijwel alle percelen kaal zijn, bieden deze stoppels dekking, groene delen en zaden, wellicht ook insecten. 


\section{$7 \quad$ Aanbevelingen}

De uitkomsten van dit onderzoek, en dan met name de goede resultaten die met de overwinterende stoppels zijn geboekt geven ons aanleiding tot het doen van de volgende aanbevelingen:

$>$ Vertaal de onderzoeksresultaten van dit onderzoek in een maatwerkpakket

Akkervogelvriendelijk bouwplan voor akkervogels onder de subsidieregeling agrarisch natuur- en landschapsbeheer (ANLb).

$>$ Het onderzoek is beperkt van opzet geweest, voor het vogel- en het insectenonderzoek zijn de beperkingen van het onderzoek benoemd. Wanneer de uitkomsten van dit onderzoek vertaald worden naar een maatwerkpakket en ook daadwerkelijk als een ANLb pakket wordt opgenomen in de subsidieregeling voor agrarisch natuurbeheer, kunnen op relatief goedkope manier en grotere schaal gegevens worden verkregen over broedsucces voor akkervogels.

Voor insecten zou een meerjarige proef nodig zijn met monitoring over een groter deel van het broedseizoen, dit om betrouwbare cijfers te krijgen of een teelt van zomergranen met minder inzet van gewasbescherming en een geringere zaaizaaddichtheid daadwerkelijk leidt tot meer insecten dan gangbaar geteelde wintertarwe.

$>$ Verder is het aan te bevelen om meer onderzoek te doen naar het verder optimaliseren van dit akkervogelvriendelijk bouwplan. Tijdens dit onderzoek zijn hiervoor al ideeën aangedragen door deelnemende agrariërs en Vogelbescherming. Hierbij zou ook de interactie en effecten van combinatie met andere ANLb pakketten, zoals Kruidenrijke akkerfaunaranden, kunnen worden meegenomen. 


\section{Dankwoord}

Onze dank gaat uit naar de provincie Groningen voor de financiering van dit onderzoek en naar de negen ondernemers die hebben meegewerkt door gedurende drie jaar zomergraan op één van hun percelen te telen en daarvoor gegevens over teelt en ervaringen met ons te delen.

Dit onderzoek en de vele waarnemingen hadden niet uitgevoerd kunnen worden zonder de inzet van de vele vrijwilligers en experts:

- Rob Geerts, mede met assistentie van Trudy van Wijk, Tonnie Doornbos, Joke Hellenberg-Boerma, Louwke Meinardi en Catrienus Rouwé bij de onkruidmonitoring en verzamelen en verwerken van de teeltgegevens,

- Bauke Koole met medewerking van Peter Esselink (Puccimar), T.D. Jager (Natuurscope), Aart van der Spoel (Aart Telwerk) en Jacob G. Bosma bij de monitoring van broed- en wintervogels, - Frans van Alebeek, Jeroen de Rond en Trudy van Wijk, Aafke Klein, Herman Loos, Louwke Meinardi, Michiel van Welsem, Catrienus Rouwé en Koos Koop bij de insecten monitoring en determinatie.

Frans van Alebeek heeft de resultaten van de insectenmonitoring uitgebreid beschreven (Bijlage 7).

De adviezen en commentaren van de begeleidingsgroep van de ANV's Wierde \& Dijk en ANOG en Provincie Groningen, bestaande uit Trudy van Wijk, Koos Koop, Jan Okko Bosker, Henk Smit, Joachi van der Valk, Piet Glas, Monique Mellema, Catrienus Rouwé en Alco van Klinken, hebben ons geholpen de koers uit te zetten en te bewaken. Ook adviezen van Jules Bos (Vogelbescherming) en Jan van 't Hoff (provincie Groningen) hebben bijgedragen aan dit eindrapport.

Wij willen alle bovengenoemde personen hartelijk danken voor hun waardevolle inbreng. 


\section{Literatuur}

Bibby, C.J., N.D. Burgess, D.A. Hill \& S. Mustoe, 2000. Bird Census techniques, second edition. Academic press, London.

Bos, J., 2013. Graanstoppels en akkervogels. Limosa 86: 123-131.

Bos, J.F.F.P., H. Sierdsema, H. Schekkerman \& C.W.M. van Scharenburg, 2010. Een Veldleeuwerik zingt niet voor niets! Schatting van kosten van maatregelen voor akkervogels in de context van een veranderend Gemeenschappelijk Landbouwbeleid. WOt-rapport 107. Wettelijke Onderzoekstaken Natuur \& Milieu, Wageningen.

Chamberlain, D.E., Wilson, A.M., Browne, S.J. \& J.A. Vickery, 2001. Effects of habitat type and management on the abundance of skylarks in the breeding season. Journal of Applied Ecology 36, 856-870.

Clarke, R., P. Combridge \& N. Midleton, 2003. Monitoring the diets of farmbird winter seed-eaters through raptor pellet analysis. Britisch Birds 96, 260-375.

CLM Milieulat, 2017. Milieumeetlat toegelaten bestrijdingsmiddelen (https://www.milieumeetlat.nl/nl/home.html)

Cramp, S. \& K.E.L. Simmons, 2004. BWPi: Birds of the Western Palearctic interactive (DVD-ROM). BirdGuides Ltd, Sheffield.

Geerts, R.H.E.M., H. Korevaar, 2016. Akkervogelvriendelijk bouwplan met zomergraan en overwinterende stoppels. Eerste tussenrapportage, teeltjaar 2015-2016. PRI-rapport 652. Wageningen UR, Wageningen.

Hegemann, A., H.P. van der Jeugd, M. de Graaf, L.L. Oostebrink, \& B.I., Tieleman, 2010. Are Dutch skylarks partial migrants? Ring recovery data and radio-telemetry suggest local coexistence of contrasting migration strategies. Ardea 98, 135-143.

Hoff, J. van 't, 2010. Wintervogels in natuurbraak. Wierde \& Dijk, Leens.

Holland, J.M., M.A.S. Hutchison, B. Smith \& N.J. Aebischer, 2006. A review of invertebrates and seedbearing plants as food for farmland birds in Europe. Annals of Applied Biology, 148:49-71.

Koole, B., 2013. Wintertelling akker-en zangvogels in Noord-Groningen 2012-2013. Wierde \& Dijk, Leens.

Koole, B. \& Spoel van der, A., 2015. De Geelgors in de provincie Groningen. De Grauwe Gors, Avifauna Groningen, Jaargang 42.

Koole, B., 2015. Akkervogels in het Dal van de Ruiten Aa. Bauke Koole Ecologie, Onderzoek, Educatie, Groningen. In opdracht van Natuurmonumenten, Staatsbosbeheer en Vogelbescherming Nederland.

Koole, B., 2017. Broedvogels en overwinteraars in het werkgebied van Collectief Midden Groningen 2015-2016. Bauke Koole Ecologie, Onderzoek, Educatie, Groningen. In opdracht van Collectief Midden Groningen.

Kuiper, M.W., 2015. The value of field margins for farmland birds. Proefschrift WUR, Wageningen. 
Marshall, E.J.P., V.K. Brown, N.D. Boatman, P.J.W. Lutman, G.R. Squire \& L.K. Ward, 2003. The role in supporting biological diversity within crop fields. Weed Research, Volume 43, Issue 2, 77-89.

Nederlandse Fauna 5. Sovon Vogelonderzoek Nederland, 2002. Atlas van de Nederlandse Broedvogels 1998-2000. KNNV Uitgeverij \& European invertebrate Survey-Nederland, Leiden.

Van Dijk, A.J. \& A. Boele, 2011. Handleiding SOVON Broedvogelonderzoek. SOVON Vogelonderzoek Nederland, Nijmegen.

Wees, E. van, 2016. Meer vogels door extensieve teelt. Veldpost, 6 augustus 2016, pag. 15.

Wierde \& Dijk,2012. Riet een ecologische focus op sloten. Leens.

Wiersma, P., H.J. Ottens, M.W. Kuiper, A.E. Schlaich, R.H.G. Klaassen, O. Vlaanderen, M. Postma \& B.J. Koks, 2014. Analyse effectiviteit van het akkervogelbeheer in provincie Groningen. Rapport Stichting Werkgroep Grauwe Kiekendief, Scheemda.

Wilson, J.D., A.J. Morris, B.E. Arroyo, S.C. Clark, R.B. Bradbury, 1999.A review of the abundance and diversity of invertebrate and plant foods of granivorous birds in northern Europe in relation to agricultural change Agriculture, Ecosystems and Environment 75, 13-30.

Zwarts, L., R.G. Bijlsma, J. van der Kamp \& E. Wymenga, 2009. Living on the edge: wetlands and birds in a changing Sahel. KNNV Publishing Zeist. 


\section{Bijlage 1 Waargenomen akkeronkruiden op de onderzoekspercelen 2015-2017}

\begin{tabular}{|c|c|}
\hline Nederlandse naam & Wetenschappelijke naam \\
\hline \multicolumn{2}{|c|}{ één- of meerjarige zaadonkruiden } \\
\hline \multicolumn{2}{|c|}{ monocotylen } \\
\hline duist & Alopecurus myosuroides \\
\hline grote windhalm & Apera spica-venti \\
\hline hanepoot & Echinochloa crus-galli \\
\hline straatgras & Poa annua \\
\hline Timothee & Phleum pratense \\
\hline zachte dravik & Bromus hordeaceus \\
\hline \multicolumn{2}{|c|}{ dicotylen } \\
\hline akkerereprijs & Veronica agrestis \\
\hline akkervergeet-mij-nietje & Myosotis arvensis \\
\hline akkerviooltje & Viola arvensis \\
\hline beklierde duizendknoop & Persicaria lapathifolia \\
\hline blaartrekkende boterbloem & Ranunculus sceleratus \\
\hline Canadese fijnstraal & Conyza canadensis \\
\hline composiet spec. & Compositae \\
\hline echte kamille & Matricaria recutita \\
\hline ereprijs spec. & Veronica \\
\hline gekroeste melkdistel & Sonchus asper \\
\hline gele ganzebloem & Chrysanthemum segetum \\
\hline gewone duivenkervel & Fumaria officinalis \\
\hline gewone herderstasje & Capsella bursa-pastoris \\
\hline gewone hoornbloem & Cerastium fontanum \\
\hline gewone melkdistel & Sonchus oleraceus \\
\hline gewoon varkensgras & Polygonum aviculare \\
\hline grote ereprijs & Veronica persica \\
\hline grote klaproos & Papaver rhoeas \\
\hline grove varkenskers & Coronopus squamatus \\
\hline hennepnetel spec. & Galeopsis \\
\hline hoenderbeet & Lamium amplexicaule \\
\hline hondspeterselie & Aethusa cynapium \\
\hline kamille spec. & Matricaria \\
\hline kleefkruid & Galium aparine \\
\hline klein kruiskruid & Senecio vulgaris \\
\hline kleine veldkers & Cardamine hirsuta \\
\hline knopherik & Raphanus raphanistrum \\
\hline knopkruid & Galinsoga \\
\hline kroontjeskruid & Euphorbia helioscopia \\
\hline kruiskruid spec. & Senecio \\
\hline melganzevoet & Chenopodium album \\
\hline melkdistel spec. & Sonchus \\
\hline ooievaarsbek spec. & Geranium \\
\hline paarse dovenetel & Lamium purpureum \\
\hline pastinaak & Pastinaca sativa \\
\hline perzikkruid & Persicaria maculosa \\
\hline uitstaande melde & Atriplex patula \\
\hline veldereprijs & Veronica arvensis \\
\hline voederwikke & Vicia sativa \\
\hline vogelmuur & Stellaria media \\
\hline wilde peen & Daucus carota \\
\hline witte dovenetel & Lamium album \\
\hline witte krodde & Thlaspi arvense \\
\hline zwaluwtong & Fallopia convolvulus \\
\hline zwarte nachtschade & Solanum nigrum \\
\hline
\end{tabular}

\begin{tabular}{|c|c|}
\hline Nederlandse naam & Wetenschappelijke naam \\
\hline \multicolumn{2}{|c|}{ meerjarige wortelonkruiden of } \\
\hline \multicolumn{2}{|c|}{ onkruiden met uitlopers } \\
\hline \multicolumn{2}{|c|}{ monocotylen } \\
\hline Engels raaigras & Lolium perenne \\
\hline fioringras & Agrostis stolonifera \\
\hline geknikte vossestaart & Alopecurus geniculatus \\
\hline gras spec. & Gramineae \\
\hline Italiaans raaigras & Lolium multiflorum \\
\hline kweek & Elytrigia repens \\
\hline rietzwenkgras & Festuca arundinacea \\
\hline roodzwenkgras & Festuca rubra \\
\hline ruwbeemdgras & Poa trivialis \\
\hline veldbeemdgras & Poa pratensis \\
\hline \multicolumn{2}{|c|}{ dicotylen } \\
\hline akkerdistel & Cirsium arvense \\
\hline akkermelkdistel & Sonchus arvensis \\
\hline akkermunt & Mentha arvensis \\
\hline basterdwederik spec. & Epilobium \\
\hline bijvoet & Artemisia vulgaris \\
\hline gewone paardebloem & Taraxacum officinale \\
\hline gewone smeerwortel & Symphytum officinale \\
\hline gewoon biggekruid & Hypochaeris radicata \\
\hline grote brandnetel & Urtica dioica \\
\hline haagwinde & Calystegia sepium \\
\hline klein hoefblad & Tussilago farfara \\
\hline krulzuring & Rumex crispus \\
\hline ridderzuring & Rumex. obtusifolius \\
\hline smalle weegbree & Plantago lanceolata \\
\hline speerdistel & Cirsium vulgare \\
\hline veenwortel & Persicaria amphibia \\
\hline witte klaver & Trifolium repens \\
\hline \multicolumn{2}{|c|}{ overige } \\
\hline es & Fraxinus excelsior \\
\hline greppelrus & Juncus bufonius \\
\hline heermoes & Equisetum arvense \\
\hline \multicolumn{2}{|c|}{ opslag cultuurgewassen } \\
\hline aardappel & Solanum tuberosum \\
\hline bladrammenas & Raphanus sativus \\
\hline gele mosterd & Sinapis alba \\
\hline gerst & Hordeum vulgare \\
\hline haver & Avena sativa \\
\hline koolzaad & Brassica napus \\
\hline luzerne & Medicago sativa \\
\hline tarwe & Triticum \\
\hline
\end{tabular}




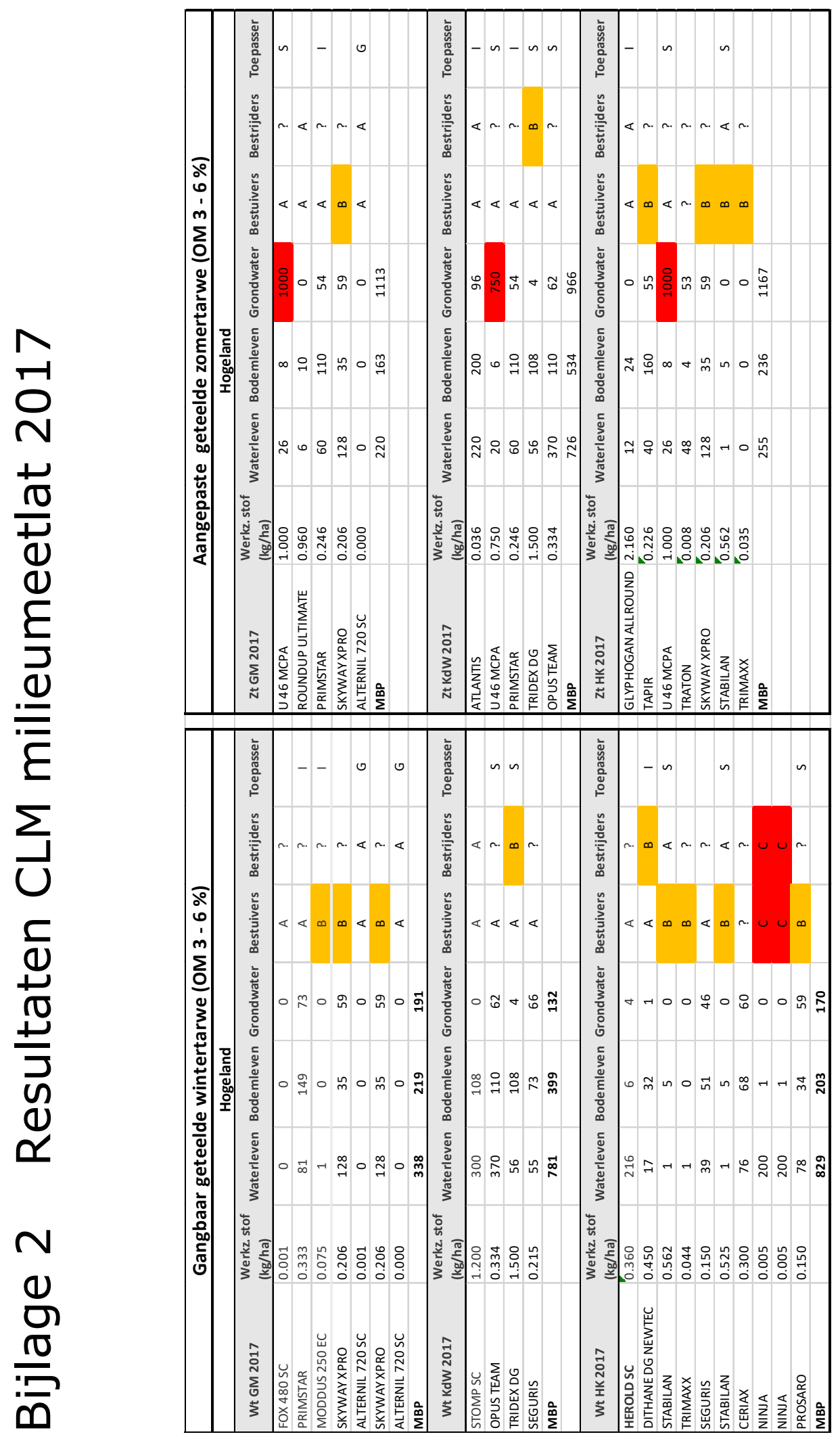




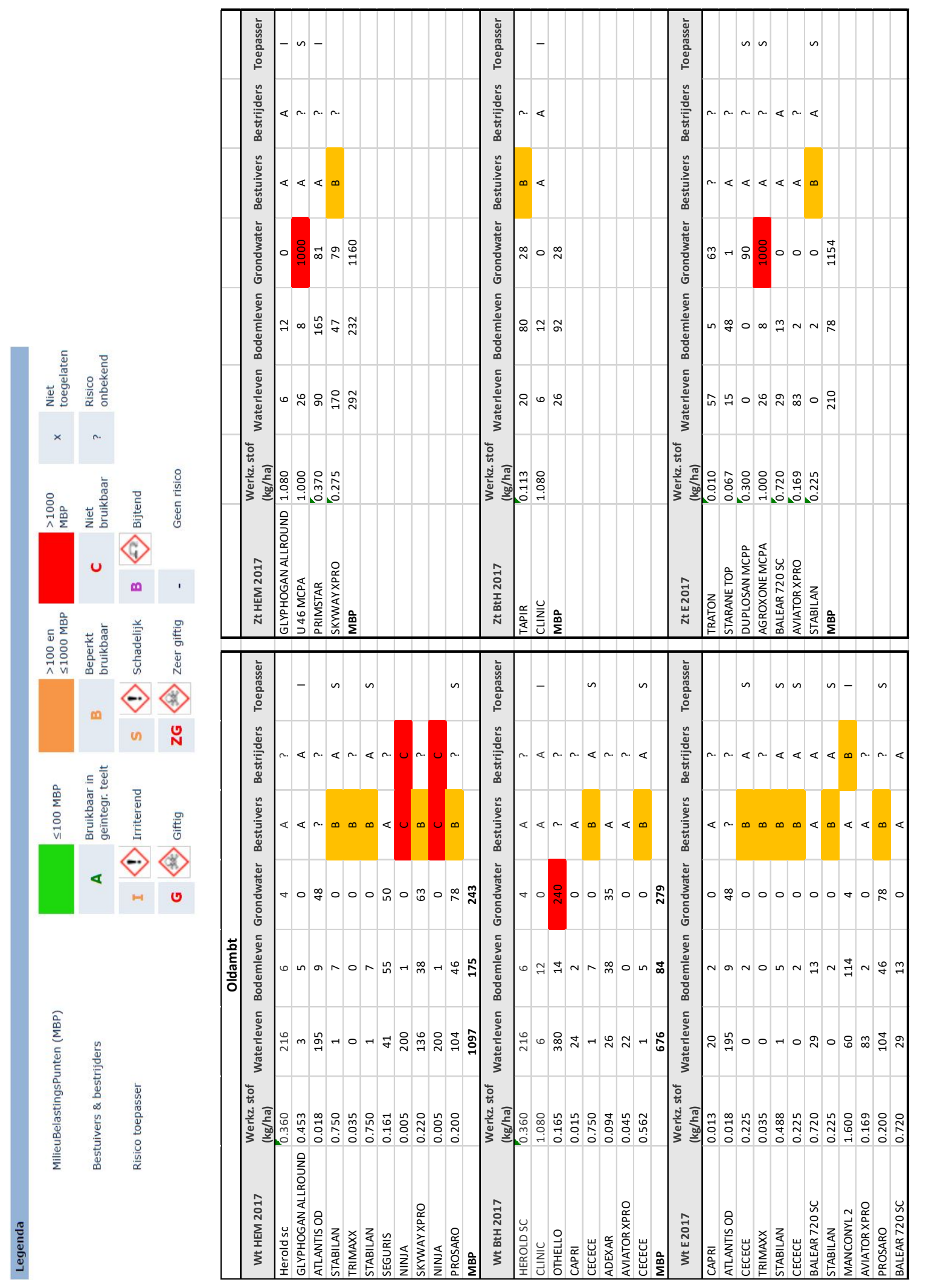




\section{Bijlage 3 Zaaddichtheidsproef 2017 Ebelsheerd}

\section{Opzet}

Op hetzelfde perceel op de SPNA locatie Ebelsheerd in Nieuw Beerta, waar ook de pilot zomertarwe is uitgevoerd, is in 2017 de proef aangelegd.

De proef is aangelegd in vier herhalingen, waarbij het effect van vier verschillende zaaidichtheden is onderzocht. Alle overige teeltmaatregelen (grondbewerking, bemesting, gewasbescherming e.d.) worden (in overeenstemming met de voorwaarden van de zomertarwe pilot) gelijkwaardig aan het praktijkperceel uitgevoerd. In de proef zijn velden van $2,0 \times 12$ meter netto en $1,5 \times 10$ meter bruto aangelegd.

\section{Aanleg proefveld}

De gehele proef is met de proefveldzaaimachine van SPNA met een rijafstand van $25 \mathrm{~cm}$ ingezaaid.

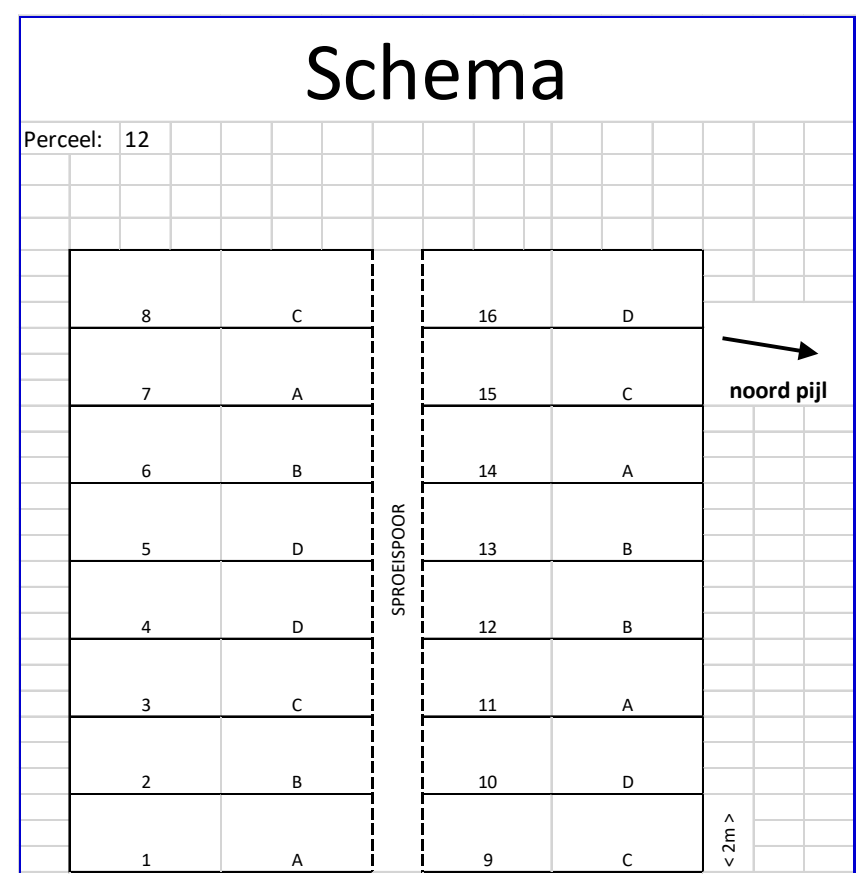

\section{Waarnemingen}

De volgende waarnemingen zijn verricht:

- Onkruidbeoordeling (rapportcijfer, waarbij 1 = heel slecht, $10=$ geen onkruid)

- Standbepaling (planten/m2)

\section{Oogst}

De oogst van het proefveld is uitgevoerd met de proefveldcombine van SPNA. Van de afzonderlijke veldjes is de opbrengst bepaald en is een analyse uitgevoerd naar de korrelkwaliteit en het vochtgehalte.

\section{Resultaten}

\begin{tabular}{|c|c|}
\hline object & zaaidichtheid $\left(\right.$ zaden $\left./ \mathrm{m}^{2}\right)$ \\
\hline A & 75 \\
\hline B & 125 \\
\hline C & 175 \\
\hline D & 225 \\
\hline
\end{tabular}

zaaidichtheid opbrengst [ton/ha] eiwit [\%] zetmeel [\%] Zeleny waarde $\mathrm{HL}$ [kg/hl]

\begin{tabular}{|l|c|c|c|c|c|}
\hline 75 & 8.0 & 13.1 & 61.7 & 45.0 & 72.4 \\
\hline 125 & 8.5 & 13.1 & 61.7 & 44.8 & 72.2 \\
\hline 175 & 9.2 & 12.9 & 62.0 & 42.5 & 72.8 \\
\hline 225 & 9.3 & 12.8 & 62.1 & 41.3 & 73.6 \\
\hline L.S.D. $(p=0,05)$ & 0.65 & 0.21 & 0.31 & 2.57 & 0.70 \\
\hline
\end{tabular}

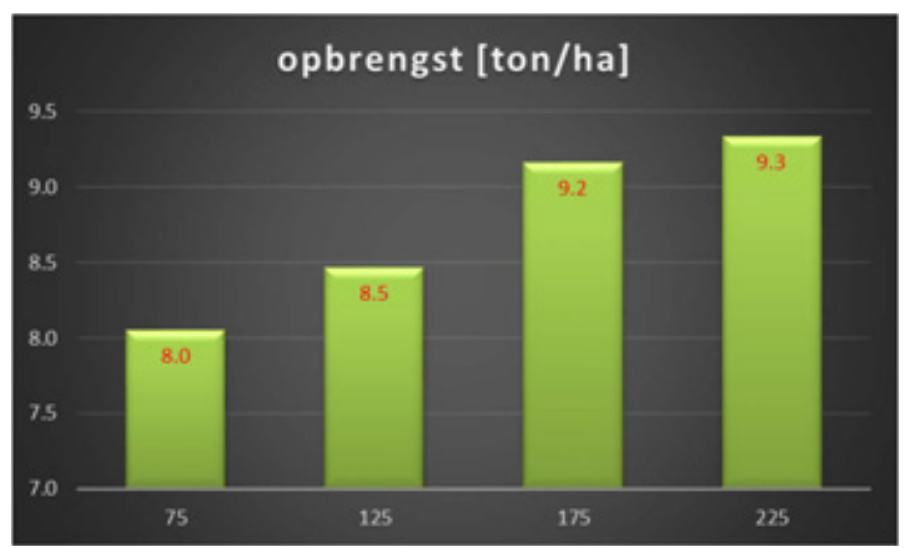




\section{Bijlage 4 Waargenomen soorten tijdens de broedvogeltellingen 2015- 2017}

\begin{tabular}{|c|c|c|c|}
\hline \multicolumn{4}{|c|}{ Broedvogels, overzomeraars en late doortrekkers } \\
\hline Nederlandse naam & Wetenschappelijke naam & Nederlandse naam & Wetenschappelijke naam \\
\hline Beflijster & Turdus torquatus & Kramsvogel & Turdus pilaris \\
\hline Bergeend & Tadorna tadorna & Kruisbek & Loxia curvirostra \\
\hline Blauwborst & Luscinia svecica & Kuifeend & Aythya fuligula \\
\hline Blauwe kiekendief & Circus cyaneus & Kwartel & Coturnix coturnix \\
\hline Blauwe reiger & Ardea cinerea & Kwartelkoning & Crex crex \\
\hline Boerenzwaluw & Hirundo rustica & Lepelaar & Platalea leucorodia \\
\hline Boompieper & Anthus trivialis & Meerkoet & Fulica atra \\
\hline Boomvalk & Falco subbuteo & Merel & Turdus merula \\
\hline Bosrietzanger & Acrocephalus palustris & Nijlgans & Alopochen aegyptiaca \\
\hline Brandgans & Branta leucopsis & Oeverloper & Actitis hypoleucos \\
\hline Bruine kiekendief & Circus aeruginosus & Oeverzwaluw & Riparia riparia \\
\hline Buizerd & Buteo buteo & Pimpelmees & Cyanistes caeruleus \\
\hline Casarca & Tadorna ferruginea & Putter & Carduelis carduelis \\
\hline Ekster & Pica pica & Regenwulp & Numenius phaeopus \\
\hline Fazant & Phasianus colchicus & Rietgors & Emberiza schoeniclus \\
\hline Geelgors & Emberiza citrinella & Rietzanger & Acrocephalus schoenobaenus \\
\hline Gekraagde roodstaart & Phoenicurus phoenicurus & Ringmus & Passer montanus \\
\hline Gele kwikstaart & Motacilla flava & Rode Wouw & Milvus milvus \\
\hline Gierzwaluw & Apus apus & Roek & Corvus frugilegus \\
\hline Goudplevier & Pluvialis apricaria & Roodborsttapuit & Saxicola rubicola \\
\hline Grasmus & Sylvia communis & Scholekster & Haematopus ostralegus \\
\hline Graspieper & Anthus pratensis & Slechtvalk & Falco peregrinus \\
\hline Grauwe gans & Anser anser & Slobeend & Anas clypeata \\
\hline Grauwe kiekendief & Circus pygargus & Sperwer & Accipiter nisus \\
\hline Groenling & Chloris chloris & Spotvogel & Hippolais icterina \\
\hline Grote bonte specht & Dendrocopos major & Spreeuw & Sturnus vulgaris \\
\hline Grote Canadese gans & Branta canadensis & Sprinkhaanzanger & Locustella naevia \\
\hline Grote gele kwikstaart & Motacilla cinerea & Stadsduif & Columba spec. \\
\hline Grote lijster & Turdus viscivorus & Steppekiekendief & Circus macrourus \\
\hline Halsbandparkiet & Psittacula krameri & Stormmeeuw & Larus canus \\
\hline Havik & Accipiter gentilis & Tapuit & Oenanthe oenanthe \\
\hline Heggenmus & Prunella modularis & Tjiftjaf & Phylloscopus collybita \\
\hline Holenduif & Columba oenas & Torenvalk & Falco tinnunculus \\
\hline Houtduif & Columba palumbus & Tureluur & Tringa totanus \\
\hline Huismus & Passer domesticus & Veldleeuwerik & Alauda arvensis \\
\hline Huiszwaluw & Delichon urbicum & Vink & Fringilla coelebs \\
\hline Hybride gans onbekend & Anser spec. & Visarend & Pandion haliaetus \\
\hline IJsvogel & Alcedo atthis & Waterhoen & Gallinula chloropus \\
\hline Kauw & Corvus monedula & Watersnip & Gallinago gallinago \\
\hline Kemphaan & Calidris pugnax & Wespendief & Pernis apivorus \\
\hline Kievit & Vanellus vanellus & Wielewaal & Oriolus oriolus \\
\hline Kleine karekiet & Acrocephalus scirpaceus & Wilde Eend & Anas platyrhynchos \\
\hline Kleine mantelmeeuw & Larus glaucoides & Winterkoning & Nannus troglodytes \\
\hline Kleine plevier & Charadrius dubius & Wintertaling & Anas crecca \\
\hline Kluut & Recurvirostra avosetta & Witgat & Tringa ochropus \\
\hline Kneu & Linaria cannabina & Witte kwikstaart & Motacilla alba \\
\hline Koekoek & Cuculus canorus & Wulp & Numenius arquata \\
\hline Kokmeeuw & Chroicocephalus ridibundus & Zanglijster & Turdus philomelos \\
\hline Koolmees & Parus major & Zilvermeeuw & Larus argentatus \\
\hline Krakeend & Anas strepera & Zwarte kraai & Corvus corone \\
\hline
\end{tabular}




\section{Bijlage 5 Waargenomen vogelsoorten tijdens de wintertellingen 2015- 2017}

\begin{tabular}{|c|c|c|c|}
\hline \multicolumn{4}{|c|}{ Overwinteraars } \\
\hline Nederlandse naam & Wetenschappelijke naam & Nederlandse naam & Wetenschappelijke naam \\
\hline Barmsijs spec. & Acanthis spec. & Koperwiek & Turdus iliacus \\
\hline Blauwe kiekendief & Circus cyaneus & Kramsvogel & Turdus pilaris \\
\hline Blauwe reiger & Ardea cinerea & Merel & Turdus merula \\
\hline Bokje & Lymnocryptes minimus & Nijlgans & Alopochen aegyptiaca \\
\hline Buizerd & Buteo buteo & Ooievaar & Ciconia ciconia \\
\hline Ekster & Pica pica & Putter & Carduelis carduelis \\
\hline Fazant & Phasianus colchicus & Rietgors & Emberiza schoeniclus \\
\hline Frater & Linaria flavirostris & Ringmus & Passer montanus \\
\hline Geelgors & Emberiza citrinella & Rode wouw & Milvus milvus \\
\hline Goudplevier & Pluvialis apricaria & Roodborst & Erithacus rubecula \\
\hline Goudvink & Pyrrhula pyrrhula & Roodborsttapuit & Saxicola rubicola \\
\hline Graspieper & Anthus pratensis & Ruigpootbuizerd & Buteo lagopus \\
\hline Grauwe gans & Anser anser & Slechtvalk & Falco peregrinus \\
\hline Grote bonte specht & Dendrocopos major & Soepgans & Anser spec. \\
\hline Grote Canadese gans & Branta canadensis & Sperwer & Accipiter nisus \\
\hline Grote gele kwikstaart & Motacilla cinerea & Spreeuw & Sturnus vulgaris \\
\hline Grote lijster & Turdus viscivorus & Steenloper & Arenaria interpres \\
\hline Grote zilverreiger & Ardea alba & Stormmeeuw & Larus canus \\
\hline Havik & Accipiter gentilis & Torenvalk & Falco tinnunculus \\
\hline Heggenmus & Prunella modularis & Veldleeuwerik & Alauda arvensis \\
\hline Holenduif & Columba oenas & Vink & Fringilla coelebs \\
\hline Houtduif & Columba palumbus & Waterpieper & Anthus spinoletta \\
\hline IJsgors & Calcarius lapponicus & Watersnip & Gallinago gallinago \\
\hline Indische gans & Anser indicus & Wilde eend & Anas platyrhynchos \\
\hline Kauw & Corvus monedula & Wilde zwaan & Cygnus cygnus \\
\hline Keep & Fringilla montifringilla & Winterkoning & Nannus troglodytes \\
\hline Kievit & Vanellus vanellus & Wintertaling & Anas crecca \\
\hline Toendrarietgans & Anser serrirostris & Witgat & Tringa ochropus \\
\hline Kneu & Linaria cannabina & Witte kwikstaart & Motacilla alba \\
\hline Kokmeeuw & Chroicocephalus ridibundus & Wulp & Numenius arquata \\
\hline Kolgans & Anser albifrons & Zanglijster & Turdus philomelos \\
\hline Koolmees & Parus major & Zwarte kraai & Corvus corone \\
\hline
\end{tabular}




\section{Bijlage 6 Akkerkruiden en hun betekenis voor zaadetende vogels}

\begin{tabular}{|c|c|c|c|c|c|}
\hline \multirow{2}{*}{$\begin{array}{l}\text { Akkeronkruiden } \\
\text { monocotylen }\end{array}$} & & & & & \multirow{2}{*}{$\begin{array}{c}\text { Betekenis voor } \\
\text { zaadetende vogels }\end{array}$} \\
\hline & & Hogeland & Oldambt & Veenkoloniën & \\
\hline duist & Alopecurus myosuroides & $x$ & $x$ & & + \\
\hline kweek & Elytrigia repens & $x$ & $x$ & $x$ & - \\
\hline straatgras & Poa annua & $x$ & $x$ & $x$ & ++ \\
\hline \multicolumn{6}{|l|}{ dicotylen } \\
\hline granen & & $x$ & $x$ & $x$ & ++ \\
\hline akkerdistel & Cirsium arvense & $x$ & $x$ & & + \\
\hline beklierde duizendknoop & Persicaria lapathifolia & $x$ & $x$ & & ++ \\
\hline echte kamille & Matricaria recutita & $x$ & $x$ & & - \\
\hline gewone duivenkervel & Fumaria officinalis & & $x$ & & + \\
\hline gewone herderstasje & & & & & + \\
\hline gewoon varkensgras & Polygonum aviculare & $x$ & $x$ & & ++ \\
\hline kleefkruid & Galium aparine & $x$ & $x$ & & - \\
\hline melganzevoet & Chenopodium album & $x$ & $x$ & $x$ & ++ \\
\hline perzikkruid & Persicaria maculosa & $x$ & $x$ & $x$ & ++ \\
\hline uitstaande melde & Atriplex patula & $x$ & $x$ & & ++ \\
\hline vogelmuur & Stellaria media & & & $x$ & ++ \\
\hline zwaluwtong & Fallopia convolvulus & $x$ & $x$ & $x$ & ++ \\
\hline
\end{tabular}

Bron: Wilson, et al. (1999), Marshall et al. (2003), Clarke et al. (2003), Holland, et al. (2006) 


\title{
Bijlage 7 Resultaten van de insectenbemonsteringen
}

Frans van Alebeek, november 2017

\begin{abstract}
Vooraf
Overal waar hier "insecten" wordt geschreven, bedoelen we in feite alle ongewervelde diertjes die aangetroffen zijn (inclusief niet-insectengroepen, zoals: slakken, regenwormen, spinnen, duizendpoten, pissebedden, enz.).

Elke bemonsteringsmethode voor insectendiversiteit en -dichtheden is selectief en representeert slechts een schatting van de werkelijkheid. Uit het oogpunt van kosten en beschikbare menskracht is gekozen voor een combinatie van potvallen (voor op de bodem levende dieren) en gele vangbakken (voor vliegende of door de wind meegevoerde fauna). Bovendien was het slechts mogelijk om één vangstronde van een week in de tweede helft van juni 2017 te doen; dus de resultaten vormen een momentopname uit een heel groeiseizoen.

Een belangrijk aandachtspunt is dat deze twee methoden geen goed beeld geven van de insecten die zich op de planten in het gewas bevinden (bladluizen, rupsen, bladhaantjes, enz.). Dat betekent dat zowel de beschikbaarheid van insecten (als voer voor vogels) als de mogelijke aanwezigheid van plagen in het gewas worden onderschat door de gekozen bemonsteringsmethoden.

Bij de analyse van de gevangen aantallen insecten ligt de focus op 3 functies:

- Insecten als voedsel voor akkervogels

- Insecten als mogelijke schadeveroorzakers in de graanteelt

- Insecten als nuttig in de graanteelt voor plaagonderdrukking

Centraal staat daarbij de vraag of de percelen zomergraan met een beperkte herbicide

behandeling/dosering een andere insectenfauna herbergen dan de controlepercelen met wintergraan. Om deze vragen te kunnen beantwoorden zijn alle insectenvangsten ingedeeld in functionele groepen (vogelvoer, plaag en/of natuurlijke vijand en/of geen van allen) en is een inschatting gemaakt van hun relatieve belang in die groep. Die indelingen worden hieronder toegelicht.
\end{abstract}

\section{Indeling in functionele groepen}

Voor de verschillende insectengroepen is bepaald in hoeverre zij belangrijk zijn als potentieel vogelvoer, als plaag in granen, of als natuurlijke vijand van gewasplagen (met name bladluizen).

\footnotetext{
Vogelvoer

Voor het vaststellen van het belang van insecten als "vogelvoer" is gebruik gemaakt van het onderzoek van Ottens et al. (2014) en Potts (2012). In het eerste onderzoek werden de poepjes van 66 kuikens van veldleeuwerik (5-8 dagen oud) onderzocht op resten van ongewervelden. In het tweede onderzoek werd de krop- en maaginhoud van 57 kuikens van de patrijs onderzocht. Hieruit volgen lijsten van groepen ongewervelden die door de kuikens van deze akkervogels worden gegeten, met een indicatie van de frequentie waarmee ze gegeten zijn. Vervolgens is het belang van de verschillende groepen als vogelvoer als volgt gecodeerd:

4 = belangrijk (vormt bij Ottens et al. of bij Potts $10 \%$ of meer van de gegeten groepen);

$\mathbf{2}=$ redelijk frequent, soms belangrijk (vormt in een van beiden onderzoeken tussen de $1 \%$ en $9 \%$ van de gegeten groepen);

$\mathbf{1}=$ (soms) frequent maar van weinig belang (vormt in beide onderzoeken minder dan $1 \%$ ) Een overzicht van de belangrijkste groepen insecten die als vogelvoer dienen wordt gegeven in Tabel 1 hieronder. In feite maken 7 insectengroepen samen tussen de $75 \%$ en $95 \%$ van het kuikendieet uit: springstaarten, bladluizen, loopkevers, emelten (de larven van langpootmuggen), rupsen, larven van bladwespen en mieren.
} 
Tabel 1 Overzicht van insectengroepen die in onderzoek van Ottens et al. (2014) voor veldleeuwerik en van Potts (2012) voor patrijs als belangrijk kuikenvoedsel naar voren komen. Codering van dat belang wordt in de tekst hierboven uitgelegd.

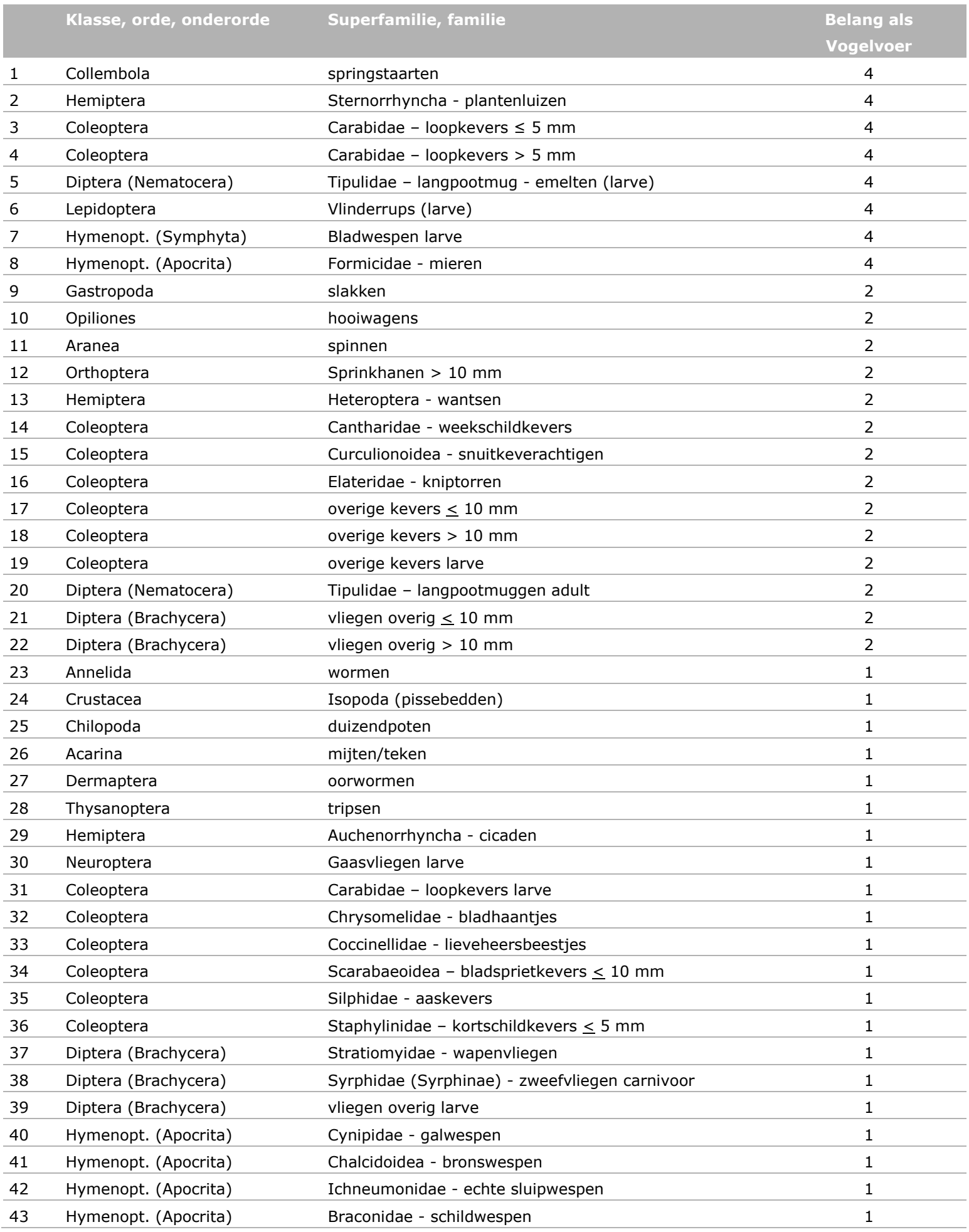

\section{Plagen in granen}

Zoals eerder aangegeven zijn potvallen en gele vangbakken niet de meest geschikte bemonsteringsmethoden om dichtheden van plagen in het gewas vast te stellen. Daarvoor is een directe inspectie van het gewas veel geschikter (zie ook Visser et al., 2011). De resultaten voor deze groep moeten daarom als een onderschatting worden beschouwd. Voor het vaststellen van plagen in granen is gebruik gemaakt van de Gewasbeschermingsgids (Oomen et al., 2003) en een Veldgids voor granen (Glas, 1997). 
De volgende plagen in graan worden genoemd: slakken, bladluizen (diverse soorten), enkele keversoorten (bladhaantjes, ritnaalden (= de larven van kniptorren) en aardvlooien), galmuggen (diverse soorten), vliegen (de Fritvlieg, Graanmineervlieg, Smalle graanvlieg en Gele halmvlieg), tripsen, graanhalmwespen, stengelboorders, springstaarten en mijten. Deze soorten zijn in te delen in de verschillende taxonomische groepen waarin de insectenvangsten zijn gesorteerd. Soorten zijn in de vangsten dus niet echt gedetermineerd, maar we nemen de taxonomische groep waarin zij vallen als een schatting voor de mate waarin deze plagen in de bemonstering voorkomen. Zo kan een lijst van schadelijke groepen worden opgesteld, maar beide publicaties geven geen uitsluitsel over het relatieve belang van de verschillende groepen. Dat belang (net als voor vogelvoer gecodeerd in 4, 2 of 1 ) is daarom gebaseerd op ervaringen en het oordeel van ondergetekende (FvA). Dit leidt tot de volgende lijst van mogelijke plagen (Tabel 2).

Tabel 2 Overzicht van insectengroepen die een plaag in graan kunnen vormen, gebaseerd op Oomen et al. (2003) en Glas (1997). Codering van het belang is een expert oordeel (FvA).

\begin{tabular}{llll} 
& Klasse, orde, onderorde & Superfamilie, familie & Belang als \\
\hline 1 & Gastropoda & slakken & 4 \\
\hline 2 & Hemiptera & Sternorrhyncha - plantenluizen & 4 \\
\hline 3 & Coleoptera & Chrysomelidae - bladhaantjes & 4 \\
\hline 4 & Coleoptera & Chrysomelidae - bladhaantjes larve & 4 \\
\hline 5 & Diptera (Nematocera) & muggen overig & 4 \\
\hline 6 & Diptera (Brachycera) & vliegen overig $\leq 10$ mm & \\
\hline 7 & Thysanoptera & tripsen & 4 \\
\hline 8 & Coleoptera & Elateridae - kniptorren & 2 \\
\hline 9 & Coleoptera & overige kevers $\leq 10$ mm & 2 \\
\hline 10 & Lepidoptera & Nachtvlinders $\leq 10$ mm & 2 \\
\hline 11 & Hymenoptera (Symphyta) & Bladwespen larve & 2 \\
\hline 12 & Acarina & mijten/teken & 2 \\
\hline 13 & Collembola & springstaarten & 1 \\
\hline 14 & Diptera (Nematocera) & Tipulidae - langpootmug-emelten (larve) & 1 \\
\hline & & & 1 \\
\hline
\end{tabular}

\section{Natuurlijke vijanden van plagen}

Hiervoor is een vergelijkbare werkwijze gevolgd, met enkele veldgidsen en een website waarop een overzicht van natuurlijke vijanden (met name van bladluizen in granen) wordt gegeven.

Gebruikte publicaties zijn: Bok (2007), Glas (1997), Syngenta (2004), Visser et al. (2011) en Groen Kennisnet (2017). Ook hier geldt weer dat het relatieve belang van de verschillende natuurlijke vijanden niet in deze publicaties wordt aangegeven en daarom door ondergetekende als expert oordeel is bepaald. De groepen natuurlijke vijanden staan gegeven in Tabel 3. 
Tabel 3 Overzicht van insectengroepen die natuurlijke vijanden van vooral bladluisplagen in graan vormen, gebaseerd op diverse bronnen (zie tekst). Codering van dat belang is een expert oordeel (FVA).

\begin{tabular}{|c|c|c|c|}
\hline & klasse, orde, onderorde & superfamilie, familie & $\begin{array}{c}\text { Belang als } \\
\text { Natuurlijke vijanden }\end{array}$ \\
\hline 1 & Aranea & spinnen & 4 \\
\hline 3 & Coleoptera & Carabidae - loopkevers $\leq 5 \mathrm{~mm}$ & 4 \\
\hline 4 & Coleoptera & Carabidae - loopkevers $>5 \mathrm{~mm}$ & 4 \\
\hline 6 & Coleoptera & Coccinellidae - lieveheersbeestjes & 4 \\
\hline 7 & Coleoptera & Coccinellidae - lieveheersbeestjes larve & 4 \\
\hline 8 & Coleoptera & Staphylinidae - kortschildkevers > 5 mm & 4 \\
\hline 9 & Diptera (Brachycera) & Syrphinae - zweefvliegen carnivoor larve & 4 \\
\hline 13 & Coleoptera & Cantharidae - weekschildkevers & 2 \\
\hline 14 & Hymenopt. (Apocrita) & Ichneumonidae - echte sluipwespen & 2 \\
\hline 15 & Hymenopt. (Apocrita) & Formicidae - mieren & 2 \\
\hline 16 & Chilopoda & duizendpoten & 1 \\
\hline 17 & Opiliones & hooiwagens & 1 \\
\hline 18 & Acarina & mijten/teken & 1 \\
\hline 19 & Dermaptera & oorwormen & 1 \\
\hline 20 & Coleoptera & Staphylinidae - kortschildkevers $\leq 5 \mathrm{~mm}$ & 1 \\
\hline 21 & Diptera (Brachycera) & Tachinidae - sluipvliegen & 1 \\
\hline
\end{tabular}

\section{Analyse}

Een pilot met 9 bedrijven, slechts één waarnemingsronde, en bemonsteringstechnieken waarvan bekend is dat de individuele resultaten grote fluctuaties vertonen, loopt een aanzienlijk risico om resultaten te geven op basis waarvan geen harde conclusies kunnen worden getrokken. Op zo'n kleine steekproef zijn er maar beperkte mogelijkheden voor een statistische toetsing van de resultaten. Bij de huidige opzet is het mogelijk om de verdelingsvrije tekentoets toe te passen. Echter, het onderscheidend vermogen daarvan is klein. Met andere woorden: alleen als er hele duidelijke en grote verschillen zijn, worden die hiermee significant onderscheiden. Uitgangspunt (nulhypothese Ho) is dat het verminderd gebruik van herbiciden en insecticiden in pilotpercelen géén invloed heeft op de diversiteit en dichtheden van insecten. In dat geval is de kans dat er op een willekeurig bedrijf (toevallig) méér insecten in het pilotperceel (zomergraan) dan in het controleperceel (wintergraan) worden gevangen even groot als de kans dat er minder insecten worden gevangen (kans $p=0,5$ ). Met behulp van de binomiale verdeling $(n=9, p=0,5)$ kan berekend worden hoe groot de kans is dat 5 (of meer) van de 9 bedrijven méér insecten in de pilotpercelen hebben, en $6 \mathrm{v} / \mathrm{d} 9,7 \mathrm{v} / \mathrm{d} 9,8 \mathrm{v} / \mathrm{d} 9$ en 9 v/d 9 bedrijven.

Samengevat zijn die kansen als in de hierna gegeven Tabel 4. Dit komt er op neer dat alleen het resultaat waarbij op 8 of 9 van de 9 bedrijven méér insecten in de pilot percelen worden gevangen, een significant resultaat geeft. Daarbij moet ook nog worden opgemerkt dat we, door verschillende functionele groepen én 2 bemonsteringsmethoden apart te toetsen, we de toets feitelijk 14x herhalen (zie Tabel 8 bij de conclusies). Indien we daarvoor onze overschrijdingskans per toets aanpassen, dan blijft alleen een resultaat waarbij 9 van de 9 bedrijven méér insecten hebben over als significant resultaat. 
Tabel 4 Overschrijdingskansen die aangeven of in het huidige onderzoek een gevonden verdeling significant afwijkt van het toeval. Zie tekst voor verdere uitleg.

\begin{tabular}{ll} 
Aantal bedrijven waarop méér insecten in het pilot perceel worden & De kans op deze uitslag \\
gevangen dan in het controle perceel & 0.260 \\
6 (of meer) $v / d 9$ bedrijven & 0.090 \\
\hline 7 (of meer) $v / d 9$ bedrijven & $0.020^{*}$ \\
\hline 8 (of meer) $v / d 9$ bedrijven & $0.002^{* *}$ \\
\hline 9 (of meer) $v / d 9$ bedrijven &
\end{tabular}

\section{Resultaten algemeen}

In totaal zijn 26.833 diertjes gevangen en gesorteerd in 90 verschillende taxonomische groepen (soms op het niveau van klasse of orde, vaak op familieniveau, en soms uitgesplitst in grootte-klassen en/of adulten en larven). Deze groepen zijn pragmatisch gekozen om enerzijds de hoeveelheid determinatiewerk zo beperkt mogelijk te houden, en anderzijds om het onderscheid in functionele groepen (vogelvoer, plagen of natuurlijke vijanden) zo groot mogelijk te houden. Een overzicht van de vangsten staat in Tabel 5 en 6 . Tabel 5 omvat 99,7\% van alle vangsten. De groepen waarvan geen of in totaal minder dan 10 exemplaren zijn gevangen, zijn uit Tabel 5 weggelaten en staan in Tabel 6. De laatste groepen, met minder dan 10 exemplaren, zijn bij de verdere analyse buiten beschouwing gelaten (dat betreft 0,25\% van de gevangen 26.833 dieren).

Bij de potvallen worden de vangsten gedomineerd door spinnen (6\%), mijten (10\%), loopkevers (> $5 \mathrm{~mm})(28 \%)$, kortschildkevers ( $\leq 5 \mathrm{~mm})(19 \%)$, overige kevers ( $\leq 10 \mathrm{~mm})(14 \%)$ en overige vliegen $(\leq 10 \mathrm{~mm})(7 \%)$. Bij de gele vangbakken is deze laatste groep, overige vliegen $(\leq 10 \mathrm{~mm})$, goed voor $66 \%$ van de vangsten, terwijl alle andere groepen onder de $5 \%$ van het totaal blijven. 
Tabel 5 Overzicht van vangsten in functionele groepen, met de totaal aantal gevangen exemplaren in de potvallen (kolom $N$ pot) en in de gele vangbakken ( $N$ bak). Het belang van verschillende groepen als vogelvoer, plaag en/of natuurlijke vijand is hiervoor in de tekst uitgelegd. Alle groepen met in totaal minder dan 10 exemplaren zijn weggelaten (zie Tabel 6).

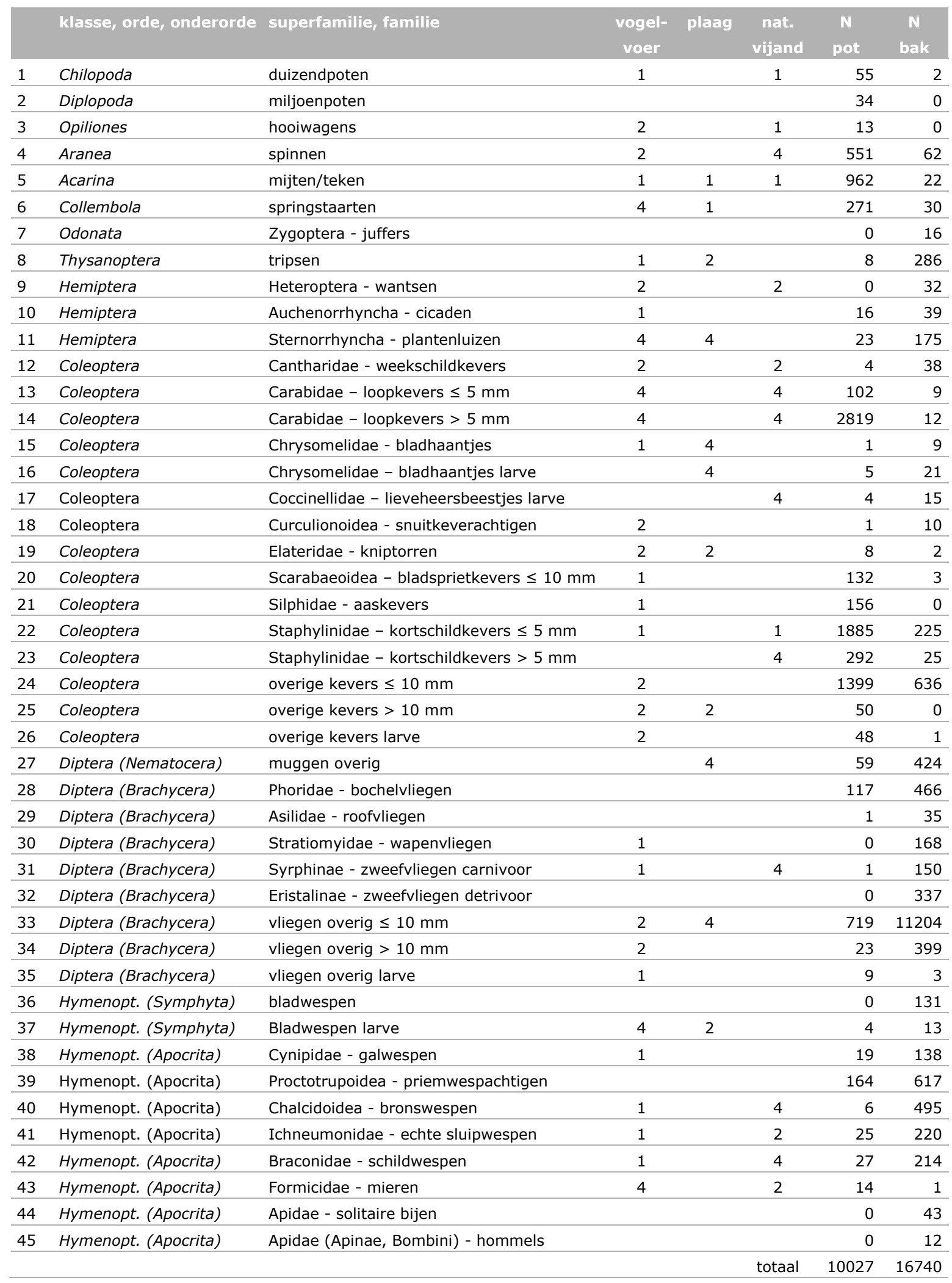


Tabel 6 Overzicht van alle functionele groepen, waarvan geen of in totaal minder dan 10 exemplaren zijn gevangen in de potvallen en gele vangbakken (zie tekst voor uitleg). Deze groepen zijn bij de verdere analyses buiten beschouwing gelaten.

\begin{tabular}{|c|c|c|c|c|c|c|}
\hline & klasse, orde, onderorde & superfamilie, familie & $\begin{array}{c}\text { vogel- } \\
\text { voer }\end{array}$ & plaag & $\begin{array}{c}\text { nat. } \\
\text { vijand }\end{array}$ & $\begin{array}{c}\mathbf{N} \\
\text { totaal }\end{array}$ \\
\hline 1 & Gastropoda & slakken & 2 & 4 & & 3 \\
\hline 3 & Crustacea & Isopoda (pissebedden) & 1 & & & 4 \\
\hline 4 & Pseudoscorpiones & boekenschorp. & & & & 0 \\
\hline 6 & Odonata & Anisoptera - echte libellen & & & & 0 \\
\hline 7 & Ephemeroptera & eendagsvliegen & & & & 0 \\
\hline 8 & Dictyoptera & kakkerlakken & & & & 0 \\
\hline 9 & Orthoptera & sprinkhanen $\leq 10 \mathrm{~mm}$ & & & & 0 \\
\hline 13 & Mallophaga & bijtende luizen & & & & 0 \\
\hline 14 & Megaloptera & Sialidae - elzenvliegen & & & & 0 \\
\hline 15 & Raphidioptera & kameelhalsvliegen & & & & 0 \\
\hline 16 & Neuroptera & gaasvliegen adult & & & & 1 \\
\hline 17 & Neuroptera & gaasvliegen larve & 1 & & 4 & 1 \\
\hline 18 & Coleoptera & Carabidae - loopkevers larve & 1 & & 4 & 8 \\
\hline 19 & Coleoptera & Cerambycidae - boktorren $\leq 10 \mathrm{~mm}$ & & & & 0 \\
\hline 20 & Coleoptera & Cerambycidae - boktorren $>10 \mathrm{~mm}$ & & & & 0 \\
\hline 21 & Coleoptera & Coccinellidae - lieveheersbeestjes & 1 & & 4 & 2 \\
\hline 27 & Diptera (Nematocera) & Bibionidae - rouwmuggen $\leq 10 \mathrm{~mm}$ & & & & 0 \\
\hline 28 & Diptera (Nematocera) & Bibionidae - rouwmuggen $>10 \mathrm{~mm}$ & & & & 0 \\
\hline 29 & Diptera (Brachycera) & Rhagionidae - snavelvliegen & & & & 1 \\
\hline 30 & Diptera (Brachycera) & Tabanidae - dazen & & & & 4 \\
\hline 31 & Diptera (Brachycera) & Tachinidae - sluipvliegen & & & 1 & 3 \\
\hline 32 & Diptera (Brachycera) & Therevidae - viltvliegen & & & & 6 \\
\hline 33 & Trichoptera & schietmotten & & & & 0 \\
\hline 34 & Lepidoptera & Papilionoidea - dagvlinders & & & & 1 \\
\hline 35 & Lepidoptera & nachtvlinders $\leq 10 \mathrm{~mm}$ & & 2 & & 2 \\
\hline 36 & Lepidoptera & nachtvlinders $>10 \mathrm{~mm}$ & & & & 3 \\
\hline 37 & Lepidoptera & vlinderrups (larve) & 4 & & & 2 \\
\hline 38 & Hymenopt. (Apocrita) & Chrysididae - goudwespen & & & & 0 \\
\hline 39 & Hymenopt. (Apocrita) & Dryinidae - tangwespen & & & & 0 \\
\hline 40 & Hymenopt. (Apocrita) & Vespidae - plooivleugelwespen & & & 1 & 0 \\
\hline 41 & Hymenopt. (Apocrita) & Pompilidae - spinnendoders & & & & 2 \\
\hline 42 & Hymenopt. (Apocrita) & overige plooiwespachtigen & & & & 2 \\
\hline 43 & Hymenopt. (Apocrita) & Crabronidae - graafwespen & & & 1 & 2 \\
\hline
\end{tabular}

\section{Resultaten potvallen}

De vangsten in de potvallen verschillen nogal tussen bedrijven, en binnen bedrijven zijn soms aanzienlijke verschillen tussen het pilotperceel en het controleperceel (Figuur 1). Per perceel werden tussen de 200 en ruim 1500 bodembeestjes gevangen. Een gedetailleerd overzicht van de vangsten per bedrijf staan in Bijlage 6. 


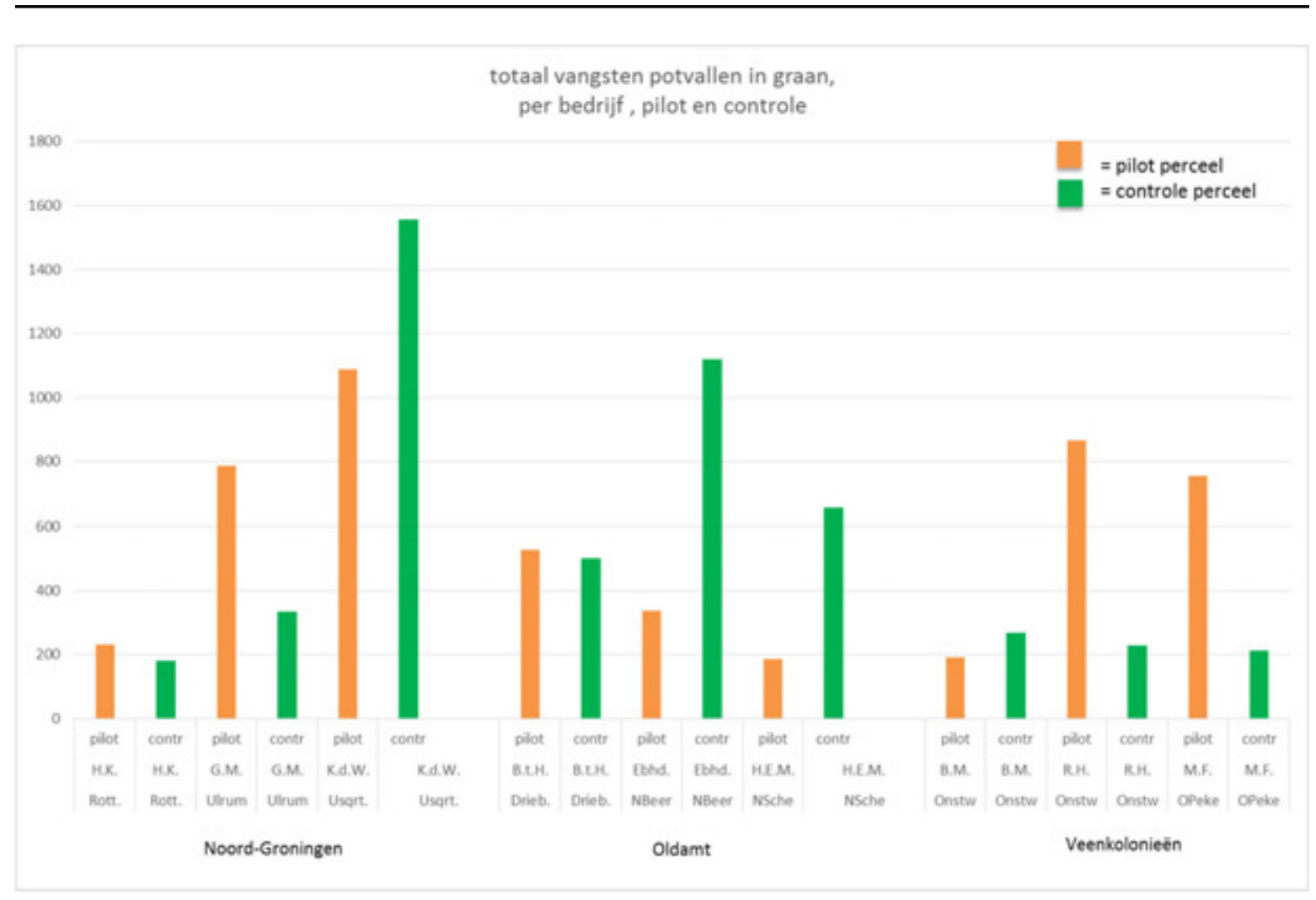

Figuur 1 Vangsten in potvallen in graanpercelen, totalen per bedrijf per pilot- en controle-perceel.

Ook als we kijken naar individuele insectengroepen, bestaan er grote verschillen tussen bedrijven en soms tussen de twee percelen op hetzelfde bedrijf (zie Bijlage 6). Zo werden op één bedrijf 131 kleine bladsprietkevers gevangen, terwijl er op de acht overige bedrijven slechts één exemplaar werd gevonden. Iets vergelijkbaars werd ook gevonden voor mijten en aaskevers. Op het pilot perceel van een bedrijf werden 900 kleine "overige" kevers gevangen, terwijl op het controleperceel van het hetzelfde bedrijf slechts 4 exemplaren werden gevangen. Een dergelijk verschil werd ook gevonden voor grote loopkevers en kleine kortschildkevers op andere bedrijven. Deze grote variatie in vangsten maakt het lastig om effecten van de pilot te beoordelen.

De vangsten lijken in de Veenkoloniën, met name op de controlepercelen, op een wat lager niveau te liggen dan in de twee andere regio's.

\section{Functionele groep "vogelvoer"}

Uit de potvalvangsten is een selectie gemaakt van de functionele groep "vogelvoer" (op basis van de eerder gemotiveerde indeling in klassen van belangrijkheid). De resultaten daarvan staan in Figuur 2 samengevat. Slechts enkele insectengroepen zijn volgens de literatuur echt belangrijk (code 4) als vogelvoer, nl. springstaarten, plantenluizen, loopkevers, emelten, vlinderrupsen, larven van bladwespen en mieren. Bekijken we de resultaten voor deze groep (vogelvoer belangrijk), dan is er op 7 van de 9 bedrijven méér gevangen in de pilotpercelen dan in de controlepercelen. Dit is een aanwijzing dat de gekozen strategie van minder bespuitingen in de pilotpercelen gunstig uitpakt voor het beschikbare voedsel voor akkervogels (Figuur 2). 


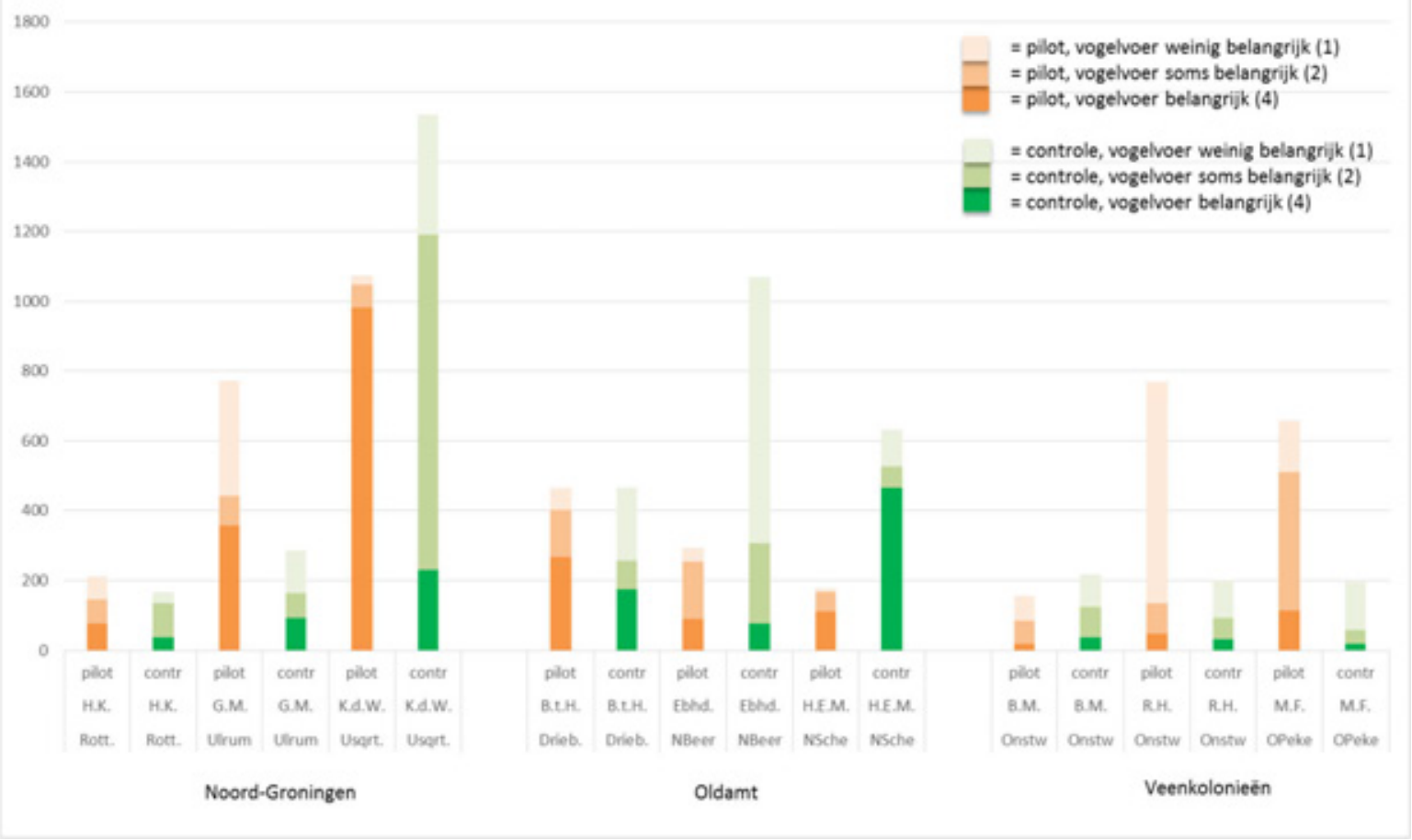

Figuur 2 Vangsten van de functionele groep "vogelvoer" in potvallen in graanpercelen, totalen per bedrijf per pilot- en controle-perceel.

Voor de twee overige categorieën (soms belangrijk $=2$ en weinig belangrijk $=1$ ) is dat beeld veel minder duidelijk, omdat er enkele bedrijven zijn met uitschieters in wisselende insectengroepen op één van beide percelen. Hoewel deze groepen in de literatuur als minder of weinig belangrijk worden genoemd, gaat het in onze vangsten soms wel om hele grote aantallen. De vraag die vooralsnog open blijft staan, is of deze insecten ook beschikbaar zijn en aantrekkelijk zijn als voedsel voor akkervogels.

\section{Functionele groep Plagen in graan.}

Zoals eerder opgemerkt geven potvallen en gele vangbakken geen duidelijk beeld van de werkelijke aanwezigheid van plagen in het gewas. De resultaten in deze groep moeten daarom met enige terughoudendheid worden bekeken.

Er zijn zoals verwacht relatief weinig plaaginsecten gevangen, waardoor de verschillen tussen de bedrijven en tussen pilot- en controlepercelen erg klein zijn (Figuur 3). Met voorzichtigheid mag worden geconcludeerd dat het er op lijkt dat de gekozen strategie in de pilotpercelen niet leidt tot een (forse) toename van plaagproblemen.

\section{Functionele groep Natuurlijke vijanden.}

Voor de insectengroepen die belangrijk $(=4)$ zijn als natuurlijke vijanden van bladluizen geldt dat zij op 7 van de 9 bedrijven talrijker zijn in de pilotpercelen dan in de controlepercelen. Dit is een aanwijzing dat de gekozen strategie van minder bespuitingen in de pilotpercelen gunstig uitpakt voor de aanwezigheid van natuurlijke vijanden van bladluisplagen (Figuur 4). Minder spuiten lijkt dus te resulteren in een betere natuurlijke bestrijding van plagen. De klasse 'soms belangrijke' natuurlijke vijanden $(=2)$ ontbreekt bijna. Het beeld voor de groep weinig belangrijke natuurlijke vijanden is niet heel duidelijk. 
totaal vangsten van functionele groep "plagen in graan" in potvallen , per bedrijf, pilot en controle

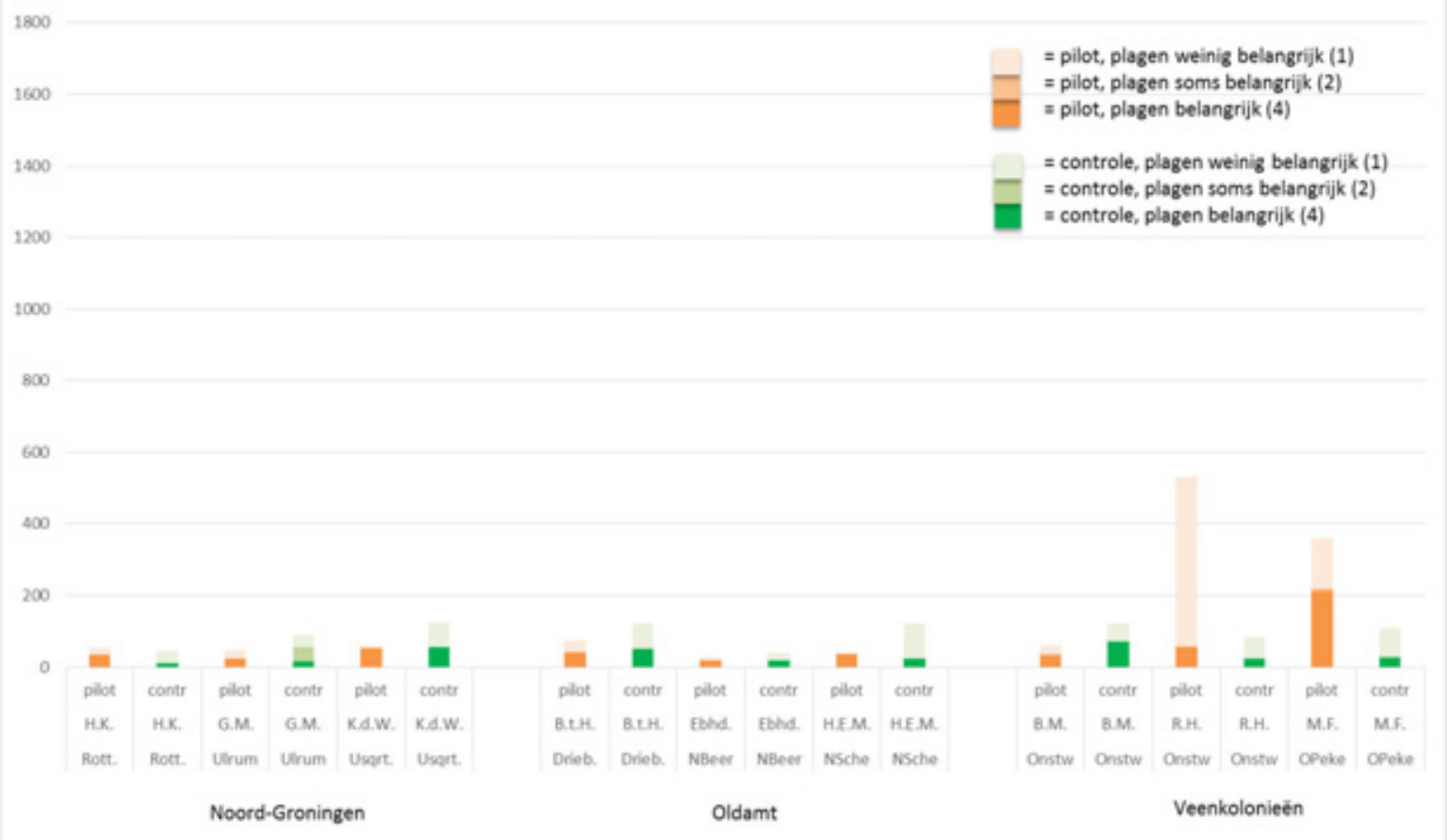

Figuur 3 Vangsten van de functionele groep "plagen in graan" in potvallen in graanpercelen, totalen per bedrijf per pilot- en controle-perceel.

totaal vangsten van functionele groep "natuurlijke vijanden" in potvallen, per bedrijf, pilot en controle

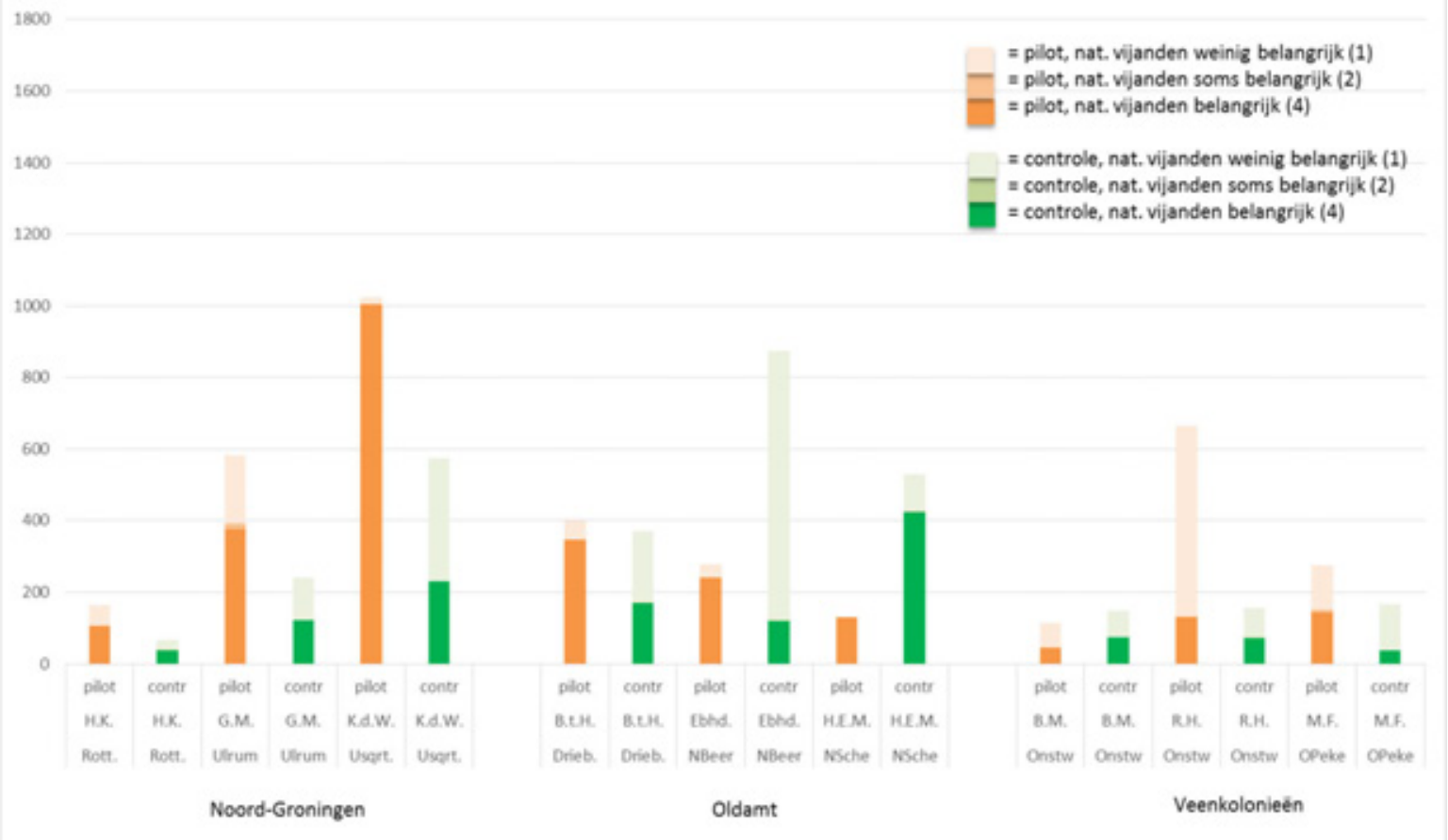

Figuur 4 Vangsten van de functionele groep "natuurlijke vijanden" in potvallen in graanpercelen, totalen per bedrijf per pilot- en controle-perceel. 


\section{Resultaten gele vangbakken}

Er zijn anderhalf maal zoveel beestjes in de gele vangbakken gevangen dan met behulp van potvallen. In de Figuren $5 \mathrm{t} / \mathrm{m} 7$ is daarom de schaal van de $Y$-as anders dan in de Figuren $2 \mathrm{t} / \mathrm{m} 4$. Figuur 8 is weer op de schaal van Figuren $2 \mathrm{t} / \mathrm{m} 4$.

Zoals hiervoor aangegeven worden de resultaten van de gele vangbakken sterk gedomineerd door één groep, "vliegen overig $\leq 10 \mathrm{~mm}$ " die $66 \%$ van de totale vangsten uitmaken. Deze groep is als soms belangrijk $(=2)$ voor vogelvoer beoordeeld en als belangrijk $(=4)$ voor de groep plagen in granen, omdat meerdere Diptera serieuze plaagproblemen in granen kunnen veroorzaken ( $\mathrm{nl}$. diverse soorten galmuggen, Fritvlieg, Graanmineervlieg, Smalle graanvlieg en Gele halmvlieg).

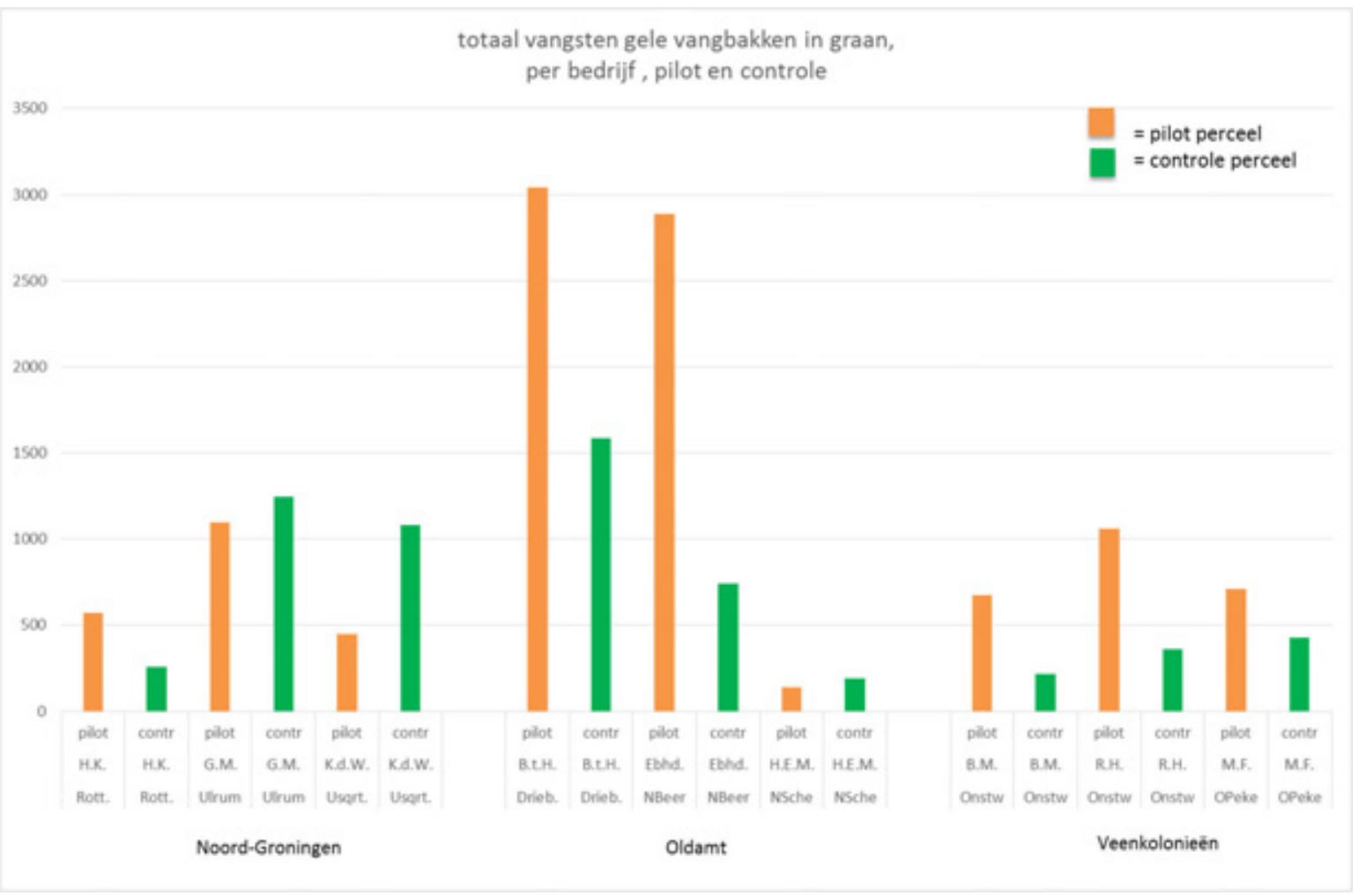

Figuur $5 \quad$ Vangsten in gele vangbakken in graanpercelen, totalen per bedrijf per pilot- en controleperceel. Let op de andere schaal van de $Y$-as dan de Figuren $1 \mathrm{t} / \mathrm{m} 4$.

Op 6 van de 9 bedrijven zijn de vangsten in de pilotpercelen hoger dan in de controlepercelen. Ook bij de gele vangbakken zien we enkele opvallende uitschieters. Twee-derde van de groep "kevers overig $\leq 10 \mathrm{~mm}$ " (ruim 440 exemplaren) is gevangen in één pilotperceel. Van de groep "vliegen overig $\leq 10 \mathrm{~mm}$ " zijn er ruim 1800 gevangen in één pilotperceel, terwijl ook pilot percelen zijn met maar 36 of 78 exemplaren (andere percelen met alles daar tussenin).

\section{Functionele groep "vogelvoer"}

De groep "vliegen overig $\leq 10 \mathrm{~mm}$ " is beoordeeld als soms belangrijk $(=2)$ voor vogelvoer, en bepaalt met de grote aantallen gevangen exemplaren daarom het hele beeld van deze functionele groep. Kijken we naar de categorie belangrijk $(=4)$ vogelvoer, dan is op 8 van de 9 bedrijven het aantal gevangen dieren in de pilot percelen groter dan in de controlepercelen (Figuur 6A). Echter, het gaat om relatief zeer kleine aantallen beestjes in de vangbakken (maximaal 64 beestjes op één perceel) zodat we hier geen grote conclusies aan kunnen verbinden. 


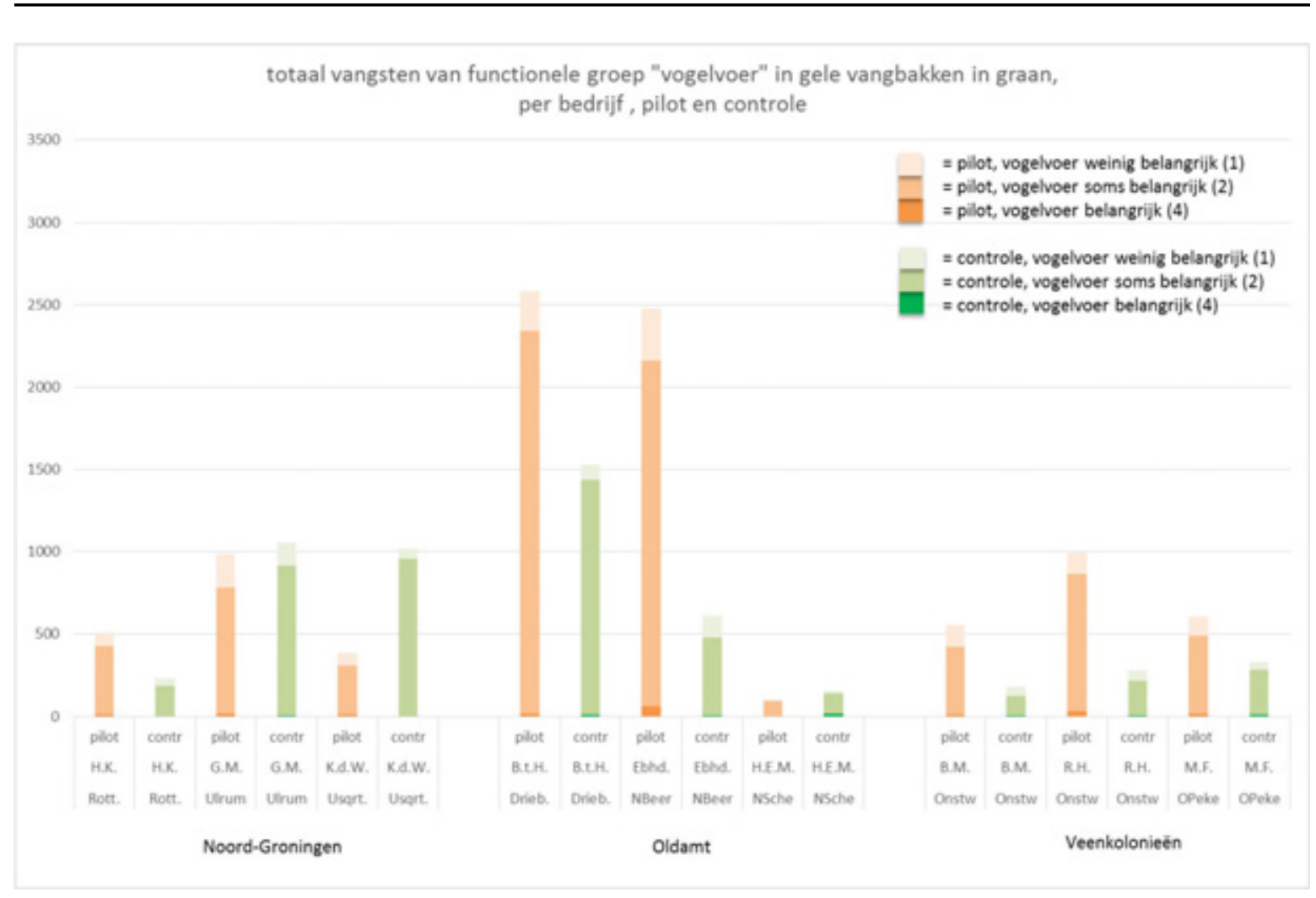

Figuur 6A Vangsten van de functionele groep "vogelvoer" in gele vangbakken in graanpercelen, totalen per bedrijf per pilot- en controle-perceel.

De groep vogelvoer soms belangrijk $(=2)$ bepaalt zoals gezegd het beeld, door de vele kleine vliegjes (Figuur 6A). In deze categorie is op 6 van de 9 bedrijven het aantal gevangen dieren in de pilot percelen groter dan in de controlepercelen. Voor de categorie weinig belangrijk $(=1)$ is dit opnieuw bij 8 van de 9 bedrijven het geval. Vanwege de relatief grote aantallen dieren die het hier betreft, zijn deze resultaten een belangrijke aanwijzing dat de pilotaanpak met verminderde inzet van herbiciden dus gunstig lijkt om meer voedsel voor akkervogels te bieden.

Vanwege de dominantie van de groep "vliegen overig $\leq 10 \mathrm{~mm}$ " is ook gekeken hoe de resultaten er uit zouden zijn wanneer we deze groep weglaten. Dat is zichtbaar in Figuur 6B. 


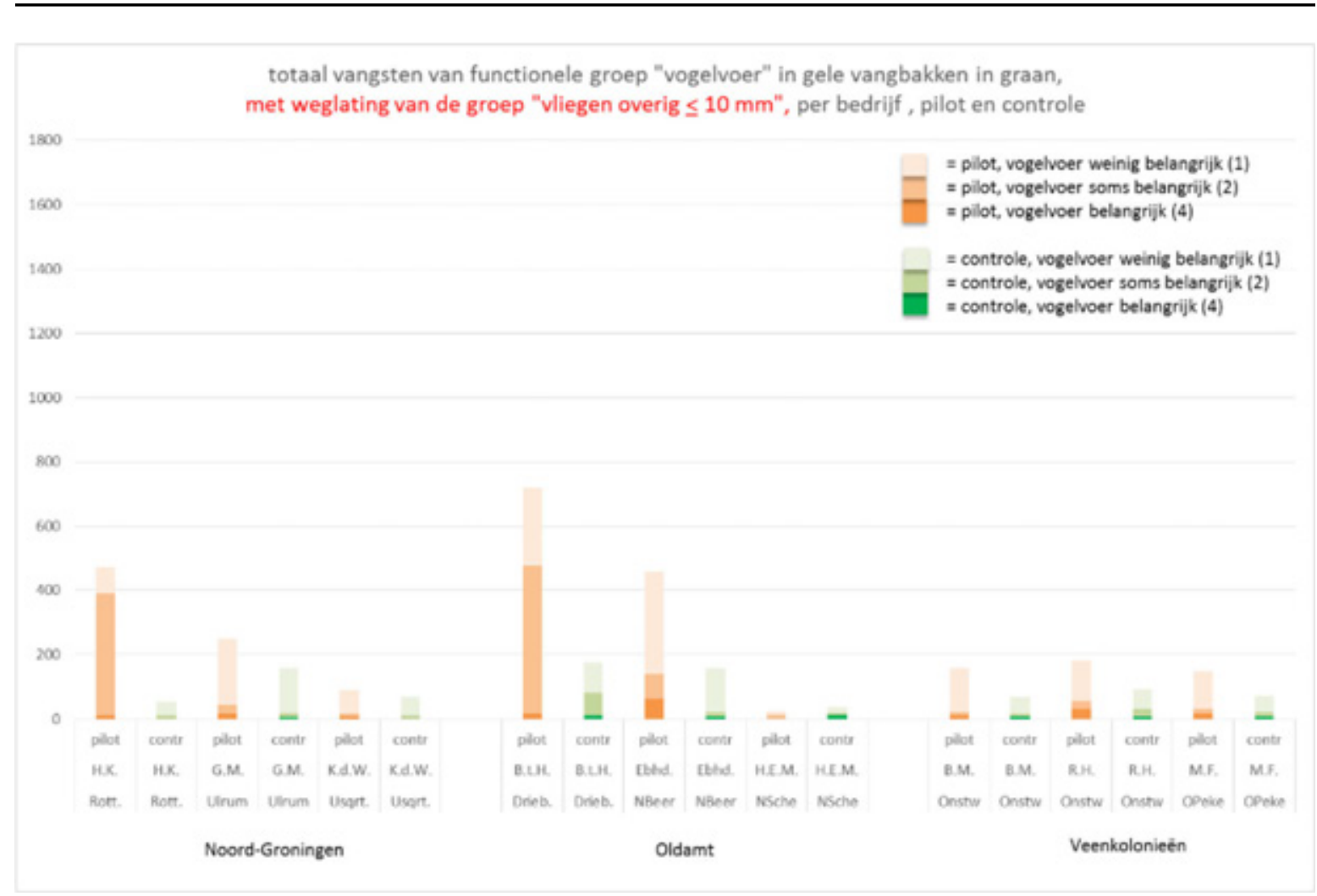

Figuur 6B Vangsten van de functionele groep "vogelvoer" in gele vangbakken in graanpercelen, met weglating van de groep "vliegen overig $<10 \mathrm{~mm}$ " uit de resultaten, totalen per bedrijf per piloten controle perceel. Let op de andere schaal van de Y-as!

Nog steeds zijn dan de totalen van vogelvoer op 8 van de 9 bedrijven groter in het pilotperceel dan in de controle percelen (Figuur 6B).

\section{Functionele groep plagen in graan}

De categorie "vliegen overig $\leq 10 \mathrm{~mm}$ " is beoordeeld als belangrijk $(=4)$ voor plagen in graan vanwege een aantal schadelijke vliegen- en muggensoorten. Omdat dit veruit de grootste insectengroep in de gele vangbakken is, domineren zij de functionele groep "plagen in graan" (Figuur 7A). Op 5 van de 9 bedrijven worden in de pilotpercelen meer plagen gevonden dan in de controlepercelen. Maar hierbij is het zeer de vraag of de honderden "vliegen overig $\leq 10 \mathrm{~mm}$ " werkelijk allemaal bestaan uit schadelijke galmuggen, fritvliegen, graanmineervliegen, smalle graanvliegen en gele halmvliegen! Daar is niet specifiek naar gekeken en op gedetermineerd. Zo nodig zou een specialist alsnog deze monsters kunnen inspecteren op het aandeel werkelijk schadelijke soorten; de monsters worden op alcohol bewaard. De categorieën soms $(=2)$ en weinig $(=1)$ belangrijk omvatten zó weinig gevangen beestjes, dat hun invloed verwaarloosbaar is.

Voorlopig valt niet uit te sluiten dat de pilot benadering zou kunnen leiden tot meer druk van vliegenplagen in graan. De kans daarop wordt als gering ingeschat, maar bij voorzetting van de pilot verdient dit aspect in elk geval aandacht. 


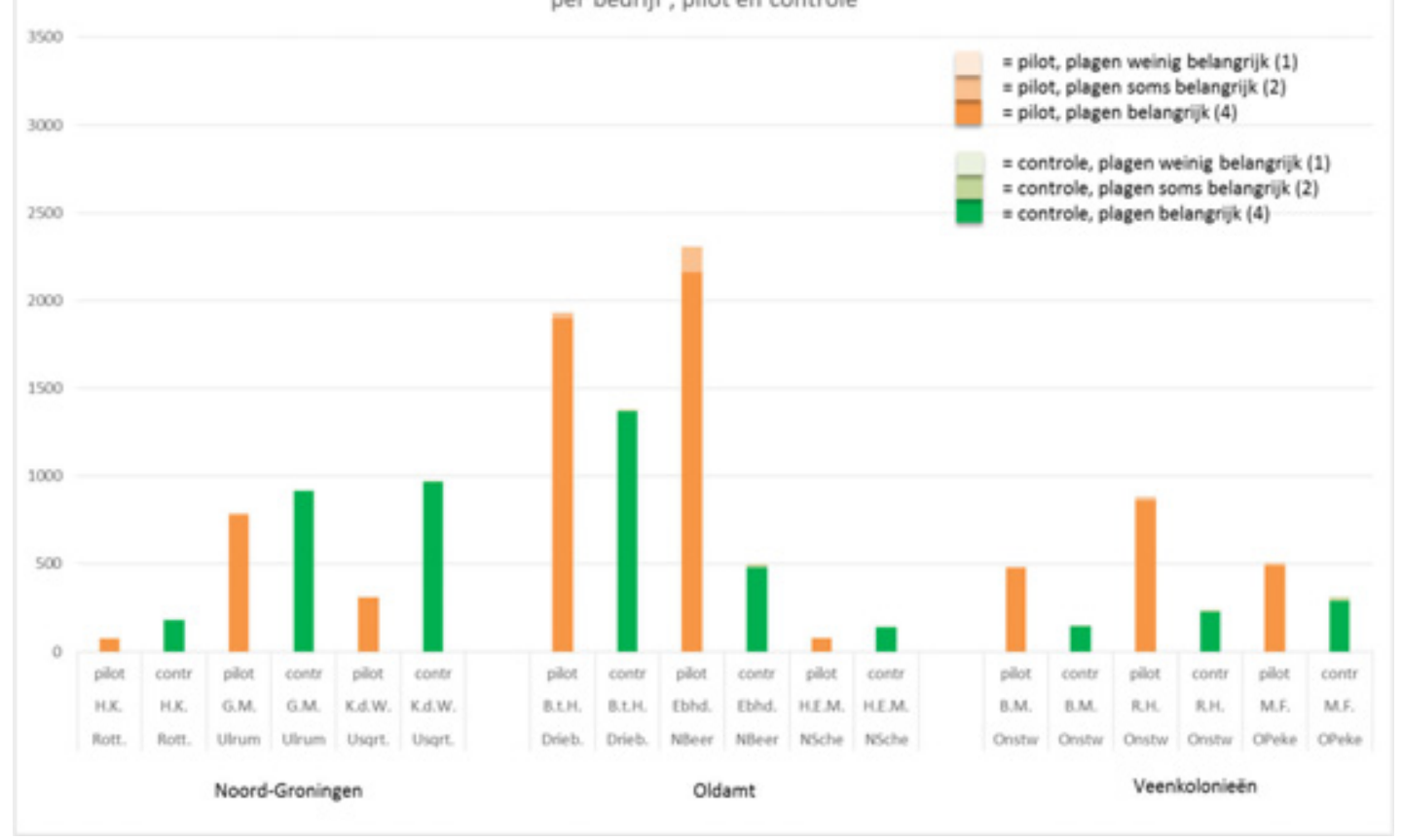

Figuur 7A Vangsten van de functionele groep "plagen in graan" in gele vangbakken in graanpercelen, totalen per bedrijf per pilot- en controle-perceel.

Net als bij het vogelvoer is bekeken hoe de resultaten voor "plagen in graan" er uit zien wanneer we de dominante groep van "vliegen overig $\leq 10 \mathrm{~mm}$ ", die belangrijk $(=4)$ is voor plagen, zouden weglaten uit de resultaten. Het effect is zichtbaar in Figuur 7B. Het effect is dramatisch, zelfs met een aangepaste $\mathrm{Y}$-as zijn er nauwelijks nog verschillen tussen de bedrijven en percelen waarneembaar. Het maximum blijft onder de 250 beestjes op een perceel. En hoewel bij 6 van de 9 bedrijven het aantal plagen groter is in pilot percelen dan in controle percelen, zijn de verschillen zodanig klein dat er niet echt reden voor zorg lijkt voor plaaggroepen anders dan de kleine vliegen.

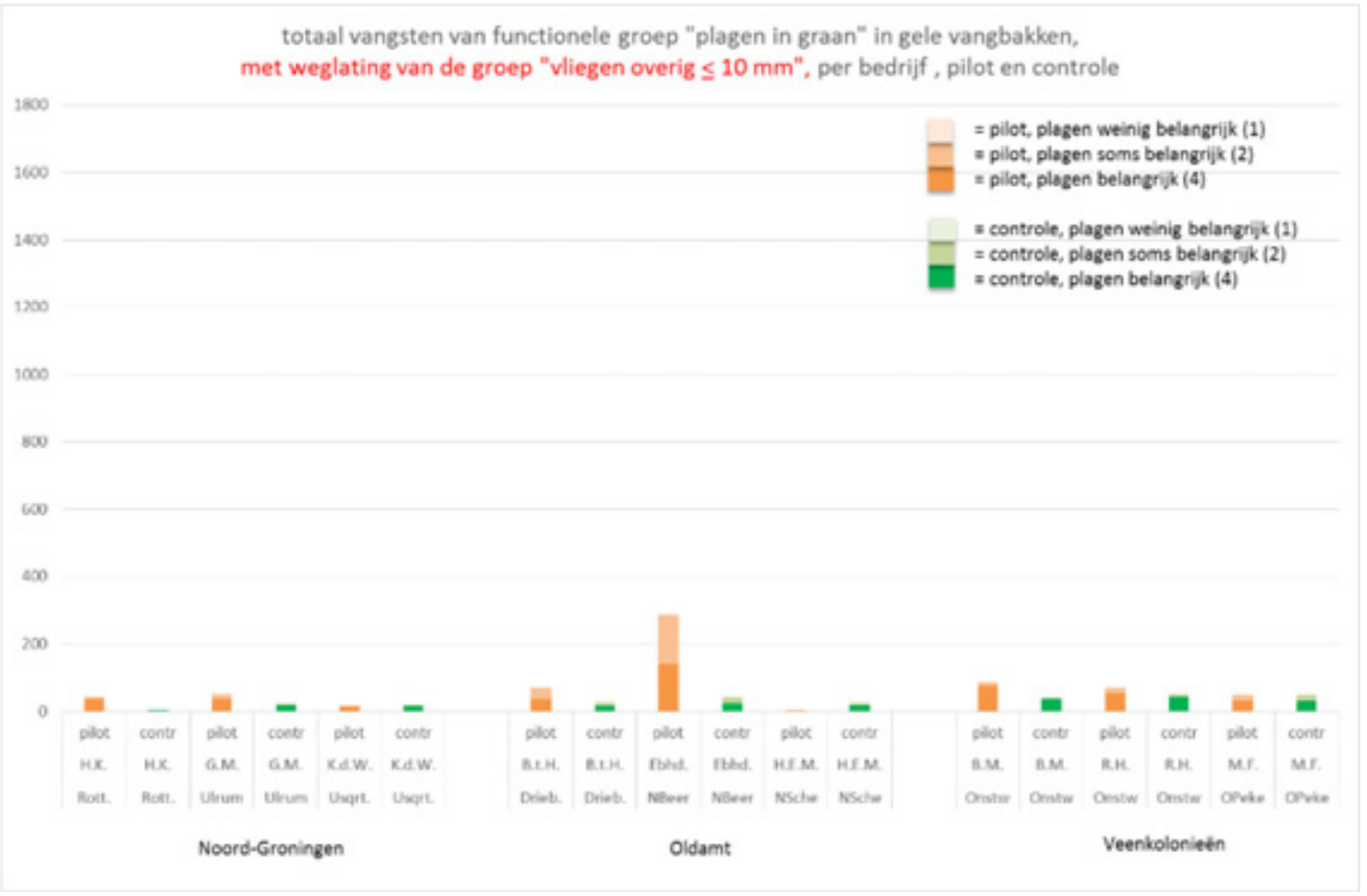

Figuur 7B Vangsten van de functionele groep "plagen in graan" in gele vangbakken in graanpercelen, met weglating van de groep "vliegen overig $<10 \mathrm{~mm}$ " uit de resultaten, totalen per bedrijf per pilot- en controle-perceel. Let op de andere schaal van de Y-as! 


\section{Functionele groep "natuurlijke vijanden"}

De aantallen natuurlijke vijanden in de gele vangbakken zijn veel geringer dan die van de functionele groepen vogelvoer en plagen, en komen tot maximaal 200 exemplaren in één perceel. Zelfs met een aangepaste schaal van de Y-as zijn er weinig verschillen zichtbaar (Figuur 8).

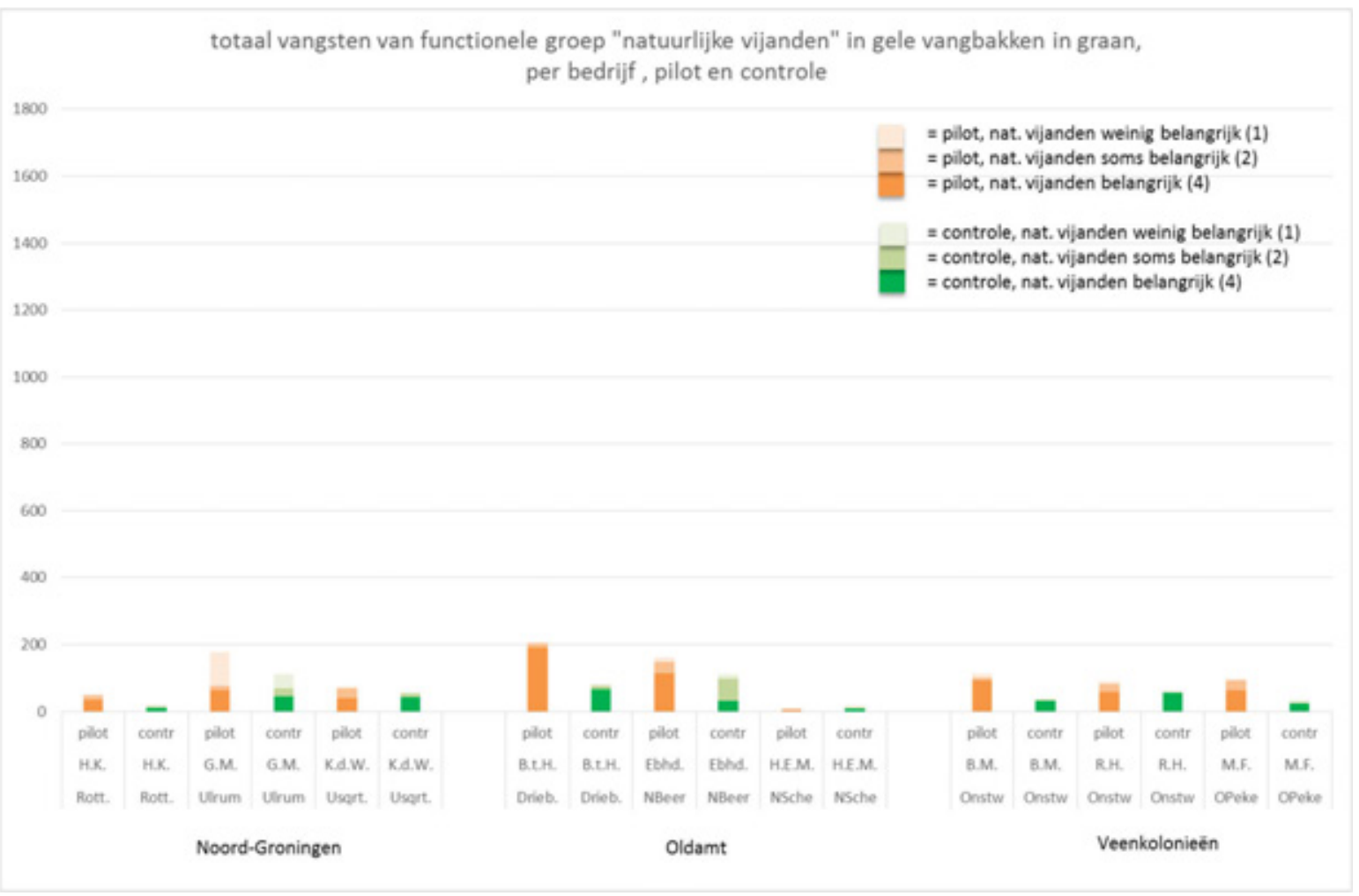

Figuur 8 Vangsten van de functionele groep "natuurlijke vijanden" in gele vangbakken in graanpercelen, totalen per bedrijf per pilot- en controle-perceel. Let op de schaal van de $Y$-as, die anders is dan in de Figuren $5 \mathrm{t} / \mathrm{m}$ 7!

Kijken we naar de categorie belangrijke $(=4)$ natuurlijke vijanden, dan is op 7 van de 9 bedrijven dat aantal hoger in de pilot percelen dan in de controle velden. Maar de aantallen waarom het gaat zijn zo laag, dat voorzichtigheid in de conclusies moet gelden. Bij de categorieën soms en weinig belangrijk zijn er nauwelijks verschillen. Deze resultaten geven een zwakke aanwijzing dat de pilot aanpak gunstig zou kunnen uitpakken voor de natuurlijke vijanden van bladluizen, maar het gaat daarbij om een zwak effect en lage dichtheden van die insectengroepen.

\section{Discussie}

De vangsten van verschillende groepen ongewervelden in Groningen zijn een momentopname van een week in één groeiseizoen en op slechts 9 bedrijven. Om te controleren of deze gegevens aansluiten bij wat bekend is over de fauna van graanpercelen, of dat er misschien sprake is van vreemde uitschieters, zijn de Groningse resultaten vergeleken met vangsten in andere onderzoeken in zomeren wintertarwe. Hiervoor zijn (deels ongepubliceerde) data uit het Biodivers onderzoek van PPO-AGV in Nagele (periode 2001 - 2006, Alebeek et al., 2005) en van het LTO-FAB project in de Hoeksche Waard (onderzoeksjaar 2006, Scheele et al., 2007) gebruikt. Bij het onderzoek in de Hoeksche Waard gaat om 60 waarnemingen uit een teeltseizoen, en het onderzoek in Nagele gaat om meer dan 200 monsters uit 6 teeltseizoenen. 
Tabel $7 \quad$ Vergelijking van de meest talrijke soortgroepen gevangen in potvallen in Groningen met eerdere onderzoeken in de Hoeksche Waard en Nagele (zie tekst voor uitleg).

\begin{tabular}{|c|c|c|c|c|}
\hline & & $\begin{array}{l}\text { Groningen } \\
2017\end{array}$ & $\begin{array}{l}\text { Hoeksche Waard } \\
2006\end{array}$ & $\begin{array}{c}\text { Nagele } \\
2001 \text { 2006 }\end{array}$ \\
\hline klasse, orde & superfamilie, familie & $\mathrm{n}=9$ & $n=60$ & $n=219$ \\
\hline Coleoptera & Kortschildkevers ( $\leq 5 \mathrm{~mm})$ & $19 \%$ & $16 \%$ & $16 \%$ \\
\hline Coleoptera & Overige kevers & $17 \%$ & $9 \%$ & $2 \%$ \\
\hline Diptera & Vliegen en muggen & $9 \%$ & $0 \%$ & $0 \%$ \\
\hline Aranea & Spinnen & $5 \%$ & $21 \%$ & $12 \%$ \\
\hline Coleoptera & Kortschildkevers (> $5 \mathrm{~mm}$ ) & $3 \%$ & $4 \%$ & $6 \%$ \\
\hline Collembola & Springstaarten & $3 \%$ & $--*$ & $--*$ \\
\hline Coleoptera & Keverlarven & $0 \%$ & $2 \%$ & $1 \%$ \\
\hline
\end{tabular}

$*=$ niet (apart) geteld in het betreffende onderzoek

Voor de bodemfauna in potvallen zijn de vangsten in Groningen in grote lijnen vergelijkbaar met die in Flevoland en de Hoeksche Waard (Tabel 7). Mijten en springstaarten zijn in die eerdere onderzoeken niet geteld en kunnen dus niet worden vergeleken. In de potvallen op de Groningse bedrijven lijken minder spinnen en meer overige kevers en vliegen en muggen te zijn gevangen dan in de eerdere onderzoeken.

Voor de gele vangbakken zijn er alleen vergelijkbare data uit het Biodivers onderzoek van PPO-AGV in Nagele bekend (Alebeek et al., 2005). De Groningse resultaten van de vangbakken lijken meer van het eerdere onderzoek af te wijken dan bij de potvallen (Tabel 8). Met name de uitschieter van kleine vliegen ( $72 \%$ in Groningen, $18 \%$ in Nagele) valt op. Op de Groningse bedrijven zijn kleine vliegen opvallend talrijk, hoewel die aantallen ook tussen de 9 bedrijven sterk wisselen. Verhoudingsgewijs lijken er in Groningen minder zweefvliegen, (sluip-)wespachtigen en plantenluizen en cicaden te zijn gevangen dan in het meerjarige onderzoek in Nagele. Oorzaken van deze verschillen zijn bij de beperkte opzet van de pilot niet te achterhalen.

Tabel $8 \quad$ Vergelijking van de meest talrijke soortgroepen gevangen in gele vangbakken in Groningen met eerdere onderzoek Nagele (zie tekst voor uitleg).

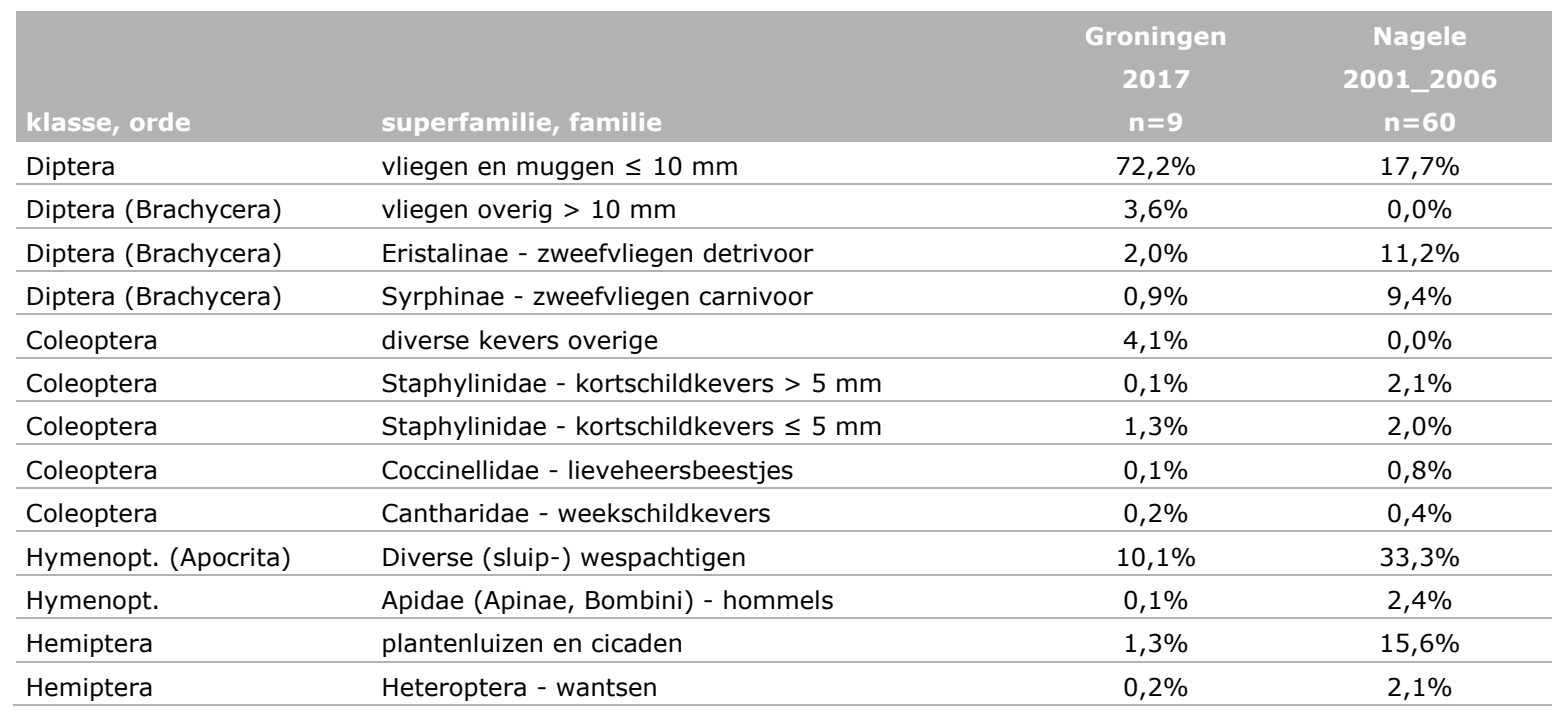


Interessant zou de vergelijking zijn met de grote datasets van 20 jaar die in Engels onderzoek zijn verzameld (o.a. Aebischer, 1991; Holland et al., 2006), maar die gegevens waren voor ondergetekende niet toegankelijk.

\section{Conclusies}

Bij de (eenmalige en kortstondige) insectenbemonstering stond de vraag centraal: Herbergen de percelen met een beperkte herbicide behandeling/dosering een andere insectenfauna dan de controlepercelen? Voor de analyse ligt de focus op 3 functies:

- Insecten als voedsel voor akkervogels

- Insecten als mogelijke schadeveroorzakers in de graanteelt

- Insecten als nuttig in de graanteelt voor plaagonderdrukking

Omdat sommige insectengroepen binnen deze functionele indeling van groter belang zijn dan andere insectengroepen, is er naast de totale vangst van die functionele groep ook gekeken naar het aandeel van de belangrijke groepen binnen die vangst. De resultaten zijn samengevat in Tabel 9.

Uit de resultaten kan (voorzichtig) de conclusie worden getrokken dat een verminderde inzet van herbiciden en insecticiden in de pilot percelen een positief effect lijkt te hebben op het insectenleven. Er worden vaker meer exemplaren gevangen van insectengroepen die belangrijk zijn als vogelvoer en als natuurlijke vijanden van plagen, zowel in de potvallen als in de gele vangbakken (Tabel 9). Dat geeft voldoende aanwijzingen om deze pilot benadering op een grotere schaal uit te testen.

Tabel 9 Samenvatting van de resultaten van de insectenbemonsteringen. Het aantal bedrijven waarop in het pilotperceel méér insecten zijn gevangen (in verschillende functionele groepen) dan in het controleperceel op hetzelfde bedrijf.

\begin{tabular}{|c|c|c|}
\hline & Potvallen & Gele vangbakken \\
\hline & Pilot > controle* & Pilot > controle* \\
\hline - Vogelvoer - totaal & 4 & 6 \\
\hline - Vogelvoer - belangrijke groepen & 7 & $(8)$ \\
\hline - Plagen in graan - belangrijke groepen & $(5)$ & $(5)$ \\
\hline - Natuurlijke vijanden -totaal & 6 & $(8)$ \\
\hline - natuurlijke vijanden - belangrijke groepen & 7 & (7) \\
\hline
\end{tabular}

Zoals in de paragraaf analyse is aangegeven, is alleen een situatie waarin op 9 van de 9 bedrijven meer insecten in de pilot percelen worden gevangen, een significant verschil. Bij 8 uit 9 bedrijven is sprake van een aanwijzing voor zo'n verschil. Maar waar in deze proef zo'n situatie wordt gevonden (zie de tabel hierboven, bij 'vogelvoer - belangrijk' en 'natuurlijke vijanden - belangrijk' in de gele vangbakken) is steeds sprake van hele geringe vangsten, zodat daar voorzichtigheid is geboden.

\section{Bronnen}

Aebischer, N.J. 1991. Twenty years of monitoring invertebrates and weeds in cereal fields in Sussex. In: Firbank, L.G., Carter, N., Darbyshire, J.F. \& Potts, G.R. (eds) The Ecology of Temperate Cereal Fields: 305-331. Blackwell Scientific Publications, Oxford.

Alebeek, F.A.N. van, Kamstra, J.H. \& Visser, A.J. (2005). Biodivers, Natuur functioneel inzetten in open teelten. PPO-Rapport (Ext. rep. 2001-2005). Lelystad: PPO.

http://library.wur.nl/WebQuery/wurpubs/fulltext/20938

Bok, N.E. van der, 2007. Natuurlijke plaagbestrijding in aardappelen en granen. Westmaas, DLV Plant, 20 pag.

Glas, H., 1997. Granen, ziekten, gebreken en aantastingen ( $2^{\mathrm{e}}$ druk). Doetinchem, Misset Uitgeverij BV, 128 pag. 
Groen Kennisnet, 2017. Beeldenbank Natuurlijke vijanden. https://wiki.groenkennisnet.nl/display/BEEL/Natuurlijke+vijanden

Holland, J.M., M.A.S. Hutchison, B. Smith \& N.J. Aebischer, 2006. A review of invertebrates and seedbearing plants as food for farmland birds in Europe. Annals of Applied Biology 148 (1): 49-71

Oomen, P.A., P.J.F. Oostelbos, R.J.J. Botden \& H.A. Duindam, 2003. Gewasbeschermingsgids 2003. Gids voor de gewasbescherming in de land- en tuinbouw en het openbaar groen. Wageningen, Planteziektenkundige Dienst \& Wageningen Academic Publishers, 477 pag.

Ottens, H.J., M.W. Kuiper, H. Flinks, J. van Ruijven, H. Siepel, B.J. Koks, F. Berendse, \& G.R. de Snoo, 2014. Do field margins enrich the diet of the Skylark Alauda arvensis on intensive farmland? Ardea $102(2), 161-171$.

Potts, G.R., 2012. Partridges. Countryside barometer. The New Naturalist Library. 465 pag.

Scheele, H., Gurp, H., Alebeek, F.A.N. van, Belder, E. den, Broek, R.C.F.M. van den, Buurma, J.S., Elderson, J., Meurs, E.J.J., Rijn, P. van, Spruijt, J., Vlaswinkel, M.E.T. \& Willemse, J., 2007. Rapportage FAB 2006 : Functionele Agro Biodiversiteit. Tilburg: LTO Projecten. http://edepot.wur.nl/30840

Syngenta, 2004. Bladluizen en hun natuurlijke vijanden. Roosendaal, Syngenta Crop Protection BV, 68 pag.

Visser, A., M. Vlaswinkel, E. van der Wal, J. Willemse \& F. van Alebeek, 2011. FAB en gewasbescherming. Het belang van goed waarnemen. Wageningen, Stichting Dienst Landbouwkundig Onderzoek, 40 pag. 
Correspondentie adres voor dit rapport: Postbus 16

6700 AA Wageningen

T 0317480700

www.wur.nl/plant-research

Rapport WPR-803
De missie van Wageningen University \& Research is 'To explore the potential of nature to improve the quality of life'. Binnen Wageningen University \& Research bundelen Wageningen University en gespecialiseerde onderzoeksinstituten van Stichting Wageningen Research hun krachten om bij te dragen aan de oplossing van belangrijke vragen in het domein van gezonde voeding en leefomgeving. Met ongeveer 30 vestigingen, 5.000 medewerkers en 10.000 studenten behoort Wageningen University \& Research wereldwijd tot de aansprekende kennisinstellingen binnen haar domein. De integrale benadering van de vraagstukken en de samenwerking tussen verschillende disciplines vormen het hart van de unieke Wageningen aanpak. 



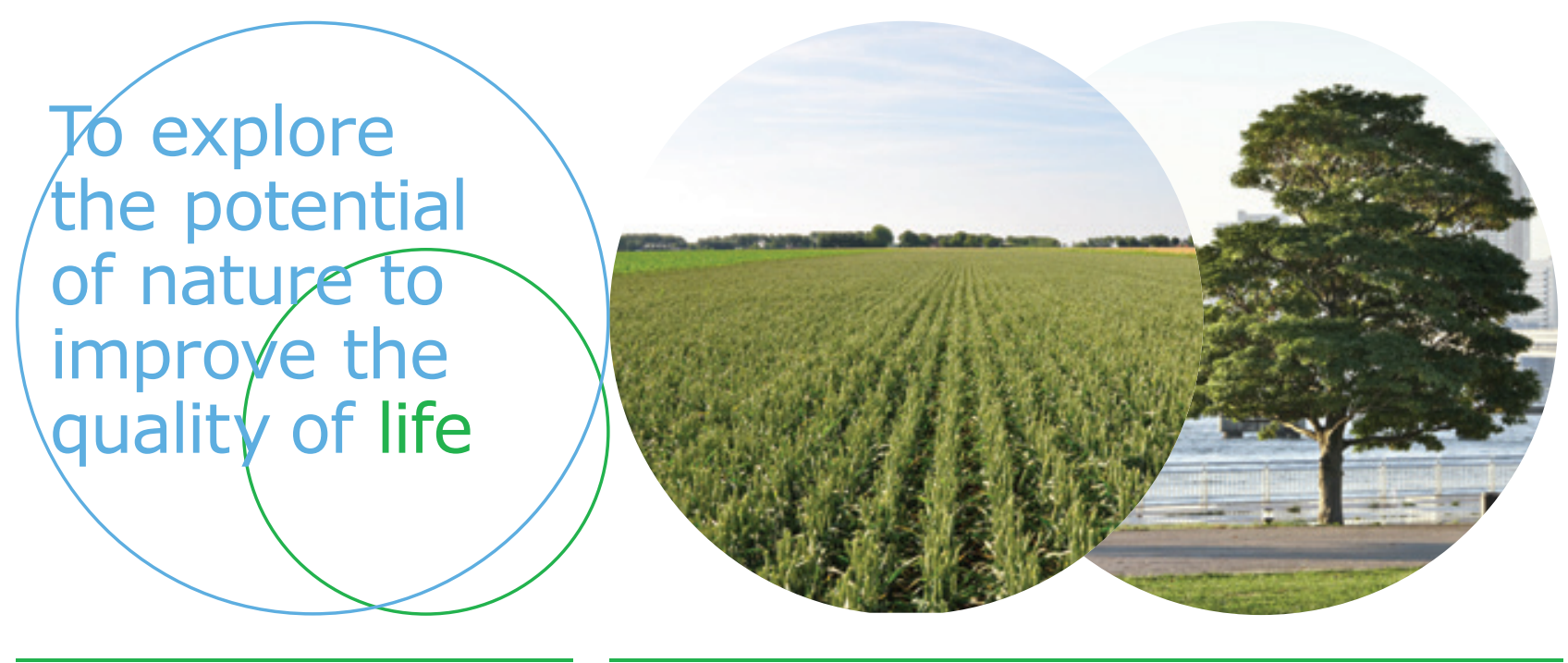

Corresponding address for this report: Postbus 16

6700 AA Wageningen

T 0317480700

www.wur.nl/plant-research

Rapport WPR-803
De missie van Wageningen University \& Research is 'To explore the potential of nature to improve the quality of life'. Binnen Wageningen University \& Research bundelen Wageningen University en gespecialiseerde onderzoeksinstituten van Stichting Wageningen Research hun krachten om bij te dragen aan de oplossing van belangrijke vragen in het domein van gezonde voeding en leefomgeving. Met ongeveer 30 vestigingen, 5.000 medewerkers en 10.000 studenten behoort Wageningen University \& Research wereldwijd tot de aansprekende kennisinstellingen binnen haar domein. De integrale benadering van de vraagstukken en de samenwerking tussen verschillende disciplines vormen het hart van de unieke Wageningen aanpak. 